Florida International University FIU Digital Commons

\title{
Determination of Nutrient Limitation on Trees Growing in Loxahatchee Impoundment Landscape Assessment (LILA) Tree Islands, Florida
}

Suresh Chandra Subedi

Florida International University, ssube001@fiu.edu

DOI: $10.25148 /$ etd.FI1 1042003

Follow this and additional works at: https://digitalcommons.fiu.edu/etd

\section{Recommended Citation}

Subedi, Suresh Chandra, "Determination of Nutrient Limitation on Trees Growing in Loxahatchee Impoundment Landscape Assessment (LILA) Tree Islands, Florida" (2011). FIU Electronic Theses and Dissertations. 350.

https://digitalcommons.fiu.edu/etd/350 


\title{
FLORIDA INTERNATIONAL UNIVERSITY \\ Miami, Florida
}

\section{DETERMINATION OF NUTRIENT LIMITATION ON TREES GROWING IN LOXAHATCHEE IMPOUNDMENT LANDSCAPE ASSESSMENT (LILA) TREE ISLANDS, FLORIDA}

\author{
A thesis submitted in partial fulfillment of the \\ requirements for the degree of \\ MASTER OF SCIENCE \\ in \\ ENVIRONMENTAL STUDIES \\ by
}

Suresh Chandra Subedi

2011 
To: Dean Kenneth Furton

College of Arts and Sciences

This thesis, written by Suresh Chandra Subedi, and entitled Determination of Nutrient Limitation on Trees Growing in Loxahatchee Impoundment Landscape Assessment (LILA) Tree Islands, Florida, having been approved in respect to style and intellectual content, is referred to you for judgment.

We have read this thesis and recommend that it be approved.

Steven F. Oberbauer

Leonard J. Scinto

Michael S. Ross, Major Professor

Date of Defense: March 28, 2011

The thesis of Suresh Chandra Subedi is approved.

\begin{tabular}{r}
$\begin{array}{r}\text { Dean Kenneth Furton } \\
\text { College of Arts and Sciences }\end{array}$ \\
\hline Interim Dean Kevin O'Shea \\
University Graduate School
\end{tabular}

Florida International University, 2011 


\section{DEDICATION}

I dedicate this thesis to my uncle and aunt, Devi and Sita. Without their support, and most of all love, the completion of this work would not have been possible. 


\section{ACKNOWLEDGMENTS}

I would like to thank Dr. Michael Ross for his time and continue guidance and truly being an excellent supervisor. I would like to thank my committee members Dr. Leonard Scinto and Dr. Steve Oberbauer for their contributions throughout the degree process, and their reviews for this thesis which have helped make it better product. I would like to thank to Dr. Jay P. Sah and Pablo Ruiz for providing me with much constructive advice, and other individuals who assisted me in the field and/or laboratory: Nate Colbert, Lawrence Lopez, Diana Johnson, Carey Rebenack, Robert Schroeder, Susanna Stoffella, Eric Cline, Michael Kline, Diana Rodriguez, and Danielle Ogurcak.

Many thanks to the South Florida Water Management District for logistic support under LILA project. I would like to thank Dr. Scinto's and Dr. Anderson's labs for provided all manner of laboratory instruments, and the instruction enabling their use. I also like to thank Dr. Sharon Ewe, Dr. Jim Fourqurean and Dr. Leo Sternberg for giving advice during the experimental design and interpretation data. I also thank the Environmental Studies Department for partial graduate funding through a teaching assistantship and the support they provided.

Finally, I would like to thank my uncle and aunt Devi and Sita, my parents Khimraj and Harimaya, my brothers Raju and Deewas, my sister Subrina, and my wife, Kalpana, who have provided unconditional support, even when they can't explain what I'm doing. 


\author{
ABSTRACT OF THE THESIS \\ DETERMINATION OF NUTRIENT LIMITATION ON TREES GROWING IN \\ LOXAHATCHEE IMPOUNDMENT LANDSCAPE ASSESSMENT (LILA) TREE \\ ISLANDS, FLORIDA \\ by
}

Suresh Chandra Subedi

Florida International University, 2011

Miami, Florida

Professor Michael S. Ross, Major Professor

The purpose of this study was to determine the general patterns of response by tree species common to Everglades Tree Islands (TI) when conditions limiting optimal growth are improved by fertilization on LILA tree islands. Experiments were conducted on constructed TI in the Loxahatchee Impoundment Landscape Assessment (LILA). Thirty-six trees of two species, Annona glabra and Chrysobalanus icaco, were randomly selected on each of four tree islands. Two tree islands have peat overlying limestone cores and two are composed solely of peat. Each tree was treated with one of three nutrient regimes: $+\mathrm{N},+\mathrm{P}$, or Control (no addition of nutrients). A highly significant $\mathrm{P}-$ treatment effect on growth rate, leaf $\mathrm{TP}$ and leaf $\mathrm{N}: \mathrm{P}$ ratio were observed in both species in comparison to Control trees. In contrast, neither of the species responded to $\mathrm{N}$ fertilization. The mass $\mathrm{N}: \mathrm{P}$ ratios and $\delta^{13} \mathrm{C}$ in $\mathrm{P}$-treated trees exhibited a positive correlation with Relative Elevation (RE) for both species. These findings suggested that the tree growth at LILA tree islands was P-limited on both substrates (limestone and peat). 


\section{TABLE OF CONTENTS}

CHAPTER

PAGE

1. INTRODUCTION 1

1.1. Tree islands 2

1.2. Nutrient dynamics in tree islands 3

1.3. Experimental Fertilization 4

1.4. Determining nutrient availability 5

1.4.1. Growth response 5

1.4.2. Foliar N:P ratio 6

1.4.3. Stable isotopes

2. OBJECTIVES AND HYPOTHESES 9

$\begin{array}{ll}2.1 \text { Objectives } & 9\end{array}$

3. METHODS AND MATERIALS 12

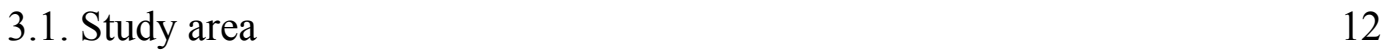

3.2. Experimental design 13

3.3. Hydrology 15

3.4. Laboratory analysis 16

3.5. Statistical analysis 17

4. RESULTS 19

4.1 Nutrient treatment effect on plant growth 19

4.2. Soil nutrient analyses 19

4.3. Foliar nutrient concentration and leaf $\mathrm{N}: \mathrm{P}$ ratios 20

4.4 Responses with nutrient treatment along hydrological gradient 21

5. DISCUSSION 23

5.1. Plant response to nutrient treatment 23

5.2. Nutrient availability and substrate effect 24

5.3. Critical N:P ratio and nutrient limitation 26

5.4. Nutrient treatment effect on leaf $\delta 15 \mathrm{~N} \quad 28$

$\begin{array}{ll}5.5 \text { Limitation of using N:P ratio } & 29\end{array}$

5.6 Background nutrient availability and nutrient application 30

5.7 Nutrient limitation along the hydrological gradient 31

5.8 Carbon-stable isotope ratio along the hydrological gradient 32

5.9 Why LILA tree islands are P-limited? 33

6. CONCLUSIONS 35

LITERATURE CITED 37 
APPENDICES

FIGURES 


\section{LIST OF FIGURES}

FIGURE

PAGE

1. Simple conceptual model for tree island nutrient dynamics. 4

2. A map showing a design of LILA. $\quad 50$

3. The average below ground depth $(\mathrm{m})$ of sediment detected at the center of the peat and limestone tree islands when groundwater wells were installed. 51

4. A picture showing nutrient treatment technique around the trees. 52

5. Comparisons of growth response between nutrient treatments for A. glabra. 53

6. Comparisons of growth response for C. icaco on limestone and peat substrates. $\quad 54$

7. Comparisons of soil TP content for A. glabra on limestone and peat substrates. 55

8. Comparisons of soil TP content between nutrient treatments for C. icaco on limestone and peat substrates. 56

9. Comparisons of soil $\mathrm{N}: \mathrm{P}$ ratio between nutrient treatments for $C$. icaco on limestone and peat substratess.

10. Comparisons of leaf TN for $A$. glabra on limestone and peat substrates. 58

11. Comparison of leaf $\mathrm{TN}$ for C. icaco on limestone and peat substrates.

12. Comparisons of leaf TP between nutrient treatments for A. glabra on limestone and peat substrates.

13. Comparisons of leaf TP between nutrient treatments for C. icaco on limestone and peat substrates.

14. Comparisons of leaf N:P between nutrient treatments for A. glabra on limestone and peat substrates.

15. Comparisons of leaf $\mathrm{N}: \mathrm{P}$ ratio between nutrient treatments of $C$. icaco on limestone and peat substrates.

16. Scatterplot showing effect of nutrient treatment on $\mathrm{N}: \mathrm{P}$ ratios for $A$. glabra.

17. Scatterplot showing effect of nutrient treatment on $\mathrm{N}: \mathrm{P}$ ratios for $C$. icaco. 
18. Comparisons of leaf $\delta^{15} \mathrm{~N}$ between nutrient treatments for $A$. glabra on limestone and peat substrates.

19. Comparisons of leaf $\delta^{15} \mathrm{~N}$ between nutrient treatments for $C$. icaco on limestone and peat substrates.

20. Comparisons of leaf $\delta^{13} \mathrm{C}$ between nutrient treatments of $A$. glabra on limestone and peat substrates.

21. A scatterplot between growth response of $\mathrm{C}, \mathrm{N}$, and P-treatment of $A$. glabra trees and relative elevation (RE).

22. A scatterplot between growth response of $\mathrm{C}, \mathrm{N}$, and P-treatment of C. icaco trees and relative elevation (RE).

23. A scatterplot between leaf N:P ratios of C, N, and P-treatment of A. glabra trees and relative elevation (RE).

24. A scatterplot between leaf N:P ratios of C, N, and P-treatment of C. icaco trees and relative elevation (RE).

25. A scatterplot between leaf $\delta^{13} \mathrm{C}$ of $\mathrm{C}, \mathrm{N}$, and P-treatment of $A$. glabra trees and relative elevation (RE).

26. A scatterplot between leaf $\delta^{13} \mathrm{C}$ of $\mathrm{C}, \mathrm{N}$, and P-treatment of $C$. icaco trees and relative elevation $(\mathrm{RE})$.

27. A scatterplot between leaf $\mathrm{N}: \mathrm{P}$ ratios and $\delta^{13} \mathrm{C}$ of $\mathrm{C}, \mathrm{N}$, and P-treatment of A. glabra trees.

28. A scatterplot between leaf $\mathrm{N}: \mathrm{P}$ ratios and $\delta^{13} \mathrm{C}$ of $\mathrm{C}, \mathrm{N}$, and P-treatment of C. icaco trees.

29. A scatterplot between leaf $\delta^{13} \mathrm{C}$ and growth response ( $\Delta$ height) for $A$. glabra.

30. A scatterplot between leaf $\delta^{13} \mathrm{C}$ and growth response ( $\Delta$ height) for $C$. icaco. 


\section{INTRODUCTION}

The Everglades is an oligotrophic system (Noe et al. 2001, Wetzel et al. 2005) with plant species adapted to the low nutrient conditions. However, it has recently been discovered that tree islands, which are integral parts of the Everglades, are biogeochemical hotspots (Wetzel et al. 2005; Ross et al. 2006; Ross and Sah, 2010). Soil P levels concentrations in tree islands are sometimes more than 500 times higher than in the surrounding marsh (Ross and Sah, 2010). Furthermore, a sharp nutrient gradient exists within each tree island from the low open marsh to the highest elevation of the island. Tree islands are also one of the many Everglades communities that are affected by hydrology, which acts through many biogeochemical pathways and through its influence on plant nutrient availability. The relationship between hydrology and nutrient dynamics may be one of the key factors to understanding how changes in hydrologic regime will affect tree islands in the Everglades. Since there have been dramatic changes in soil and water chemistry in the Everglades due to alteration of hydrological regimes (Hanan and Ross, 2010), the nutrient pattern in tree islands may also be changing. The concentrations of essential nitrogen $(\mathrm{N})$ and phosphorus $(\mathrm{P})$, are known to change along hydrologic gradients in tree islands. Nitrogen has been shown to become limiting to plant growth in highest elevation while $\mathrm{P}$ is more limiting towards the marsh (Jayachandran et al., 2004). To address the topic of tree island nutrient availability experimentally, I designed an experiment to determine if $\mathrm{N}$ or $\mathrm{P}$ limitation is responsible for growth in two major types of artificial tree islands (limestone and peat). Only $\mathrm{N}$ and $\mathrm{P}$ were examined because they are typically the important nutrients required for plant growth (Ricklefs and Miller 1999). 


\subsection{Tree islands}

Tree islands are generally defined as patches of woody vegetation embedded in a freshwater matrix (Tomlinson, 1980). They are important centers of biodiversity in the Florida Everglades and considered key indicators of the health of the Everglades ecosystem. They are found on slightly elevated region, typically 60 to $120 \mathrm{~cm}$ above adjoining slough surface (Sklar and van der Valk, 2002). They have a tear-drop shape showing the directional flow of water. Water flow may also be important in the development of nutrient gradients from the head to tail of the island. In some cases, tree island size increases through a slow sedimentation process over a long period of time, which allows them to accumulate more nutrients (Ross et al. 2006; Larsen et al. 2007).

Because their soils act as a sink for nutrients in the ecosystem (Jayachandran et al. 2004; Wetzel et al. 2007), tree islands may play an important role in regulating nutrient dynamics i.e., in maintaining the oligotrophic nature of surrounding marshes (Wetzel et al. 2005). The biogeochemistry of the rooting environment, which emerges from the interaction of substrate with local hydrology, plays an important role in maintaining tree island structure and function (Stoffella et al. 2010). There are two distinct categories of tree islands found in the Everglades based on underlying substratum: those composed entirely of peat (pop-up or battery islands) and those built up on limestone bedrock (fixed or limestone islands) (Sklar and van der Valk 2002). 


\subsection{Nutrient dynamics in tree islands}

Tree islands are considered biogeochemical hotspots. The concentrations of total P was recorded as high as $50000 \mathrm{mg}$ TP kg-1 dry weight soil (dw) in surface soil in tree island heads (hardwood hammocks) as compared to about $100 \mathrm{mg}$ TP $\mathrm{kg}-1 \mathrm{dw}$ in the surrounding marsh soils (Ross and Sah, 2010). In contrast, soil total N was found to be highest in flooded areas and decreasing with higher elevation (Ross et al. 2006). Several nutrient distribution mechanisms have been postulated for Everglades tree islands, and magnitude of each is currently debated (Wetzel et al. 2005). Processes considered as possibilities leading to nutrient accumulation, particularly for $\mathrm{P}$, in tree islands include: surface water flow, atmospheric deposition, precipitation, groundwater upwelling, deposition of guano by birds and animal feces, and bedrock mineralization, among others (Wetzel et al. 2005, Ross et al. 2006). In contrast, the total nitrogen in tree island soils primarily depends on soil organic matter content and its interaction with hydrology (Jayachandran et al., 2004). As trees establish and grow, litterfall leads to the increasing accumulation of organic matter. Organic matter decomposition process further accentuates differences in nutrient availability among sites. Anaerobic conditions in the marsh slow the rate of decomposition and enhance organic matter and $\mathrm{N}$ accumulation. Upland areas, in contrast, are usually well drained, causing litter and organic matter to decompose aerobically and nitrogen to be mineralized rapidly. The result is slower organic matter accumulation and increased leaching of $\mathrm{N}$ out of the system (Austin and Vitousek, 1998). Thus, differences in hydroperiod and nutrient distribution between the elevated center of tree islands and their lower fringes may lead to patterns in nutrient accumulation and availability, i.e., relative N-limitation at upslope and P-limitation 
downslope. Moreover, nutrient availability may also be affected by substrate type as species growth response varies between limestone and peat islands (Stoffella et al., 2010).

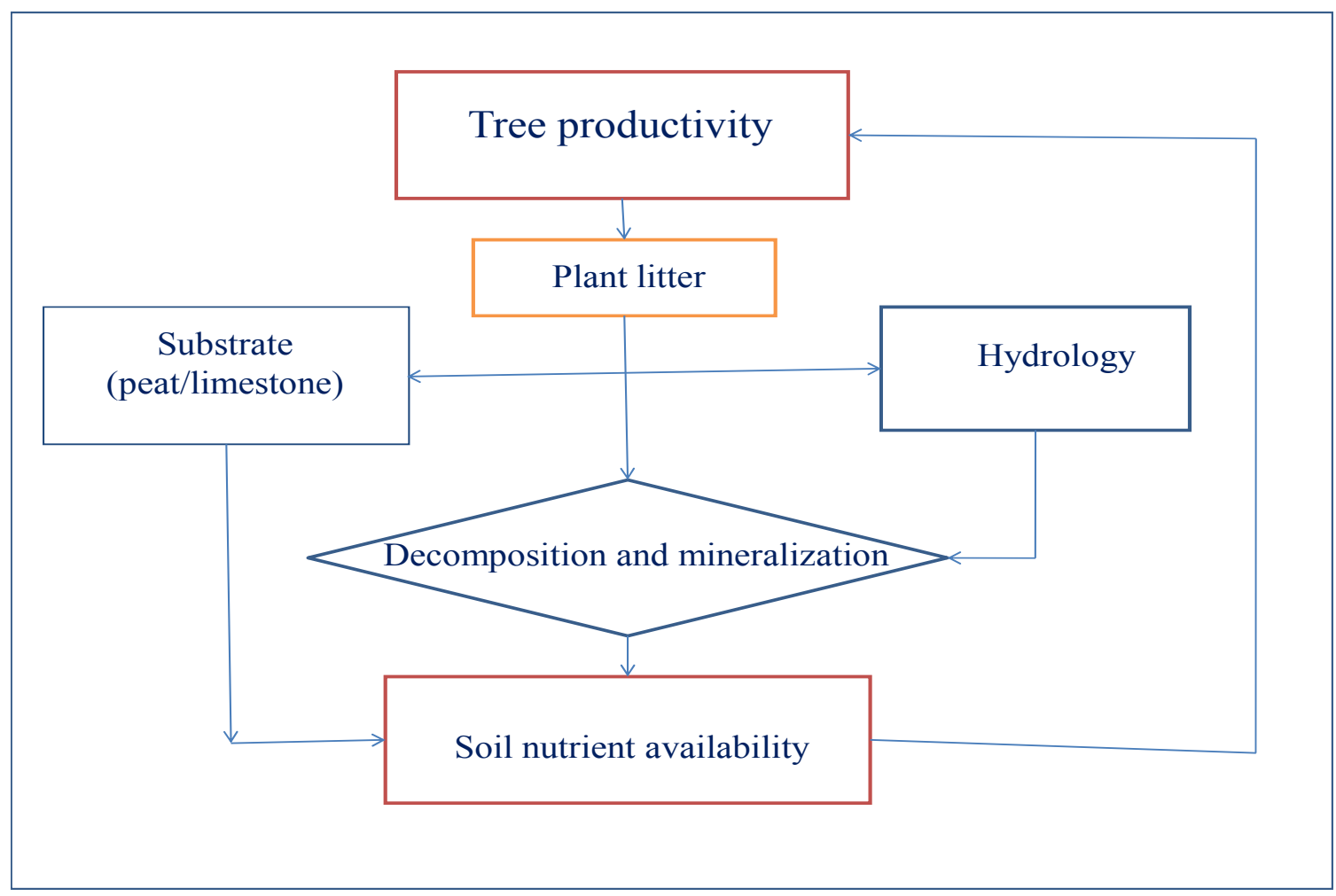

Figure 1. Simple conceptual model for tree island nutrient dynamics.

\subsection{Experimental Fertilization}

Fertilization experiments have proved successful in determining the growth-limiting nutrient in various ecosystems including wetlands. The type of nutrient limitation is determined by applying a particular fertilizer to see if it significantly increases aboveground biomass and plant tissue concentrations compared with control sites (Vitousek and Howarth 1991; Koerselman and Meuleman 1996). Gusewell et al. (2003) carried out fertilization experiments in Dutch fens and dune slacks and examined treatment effects on the biomass and N:P ratios of the whole vegetation as well as individual plant 
populations. Similarly, Feller (1995) and McKee (2002) have shown that fertilization of red mangrove trees with phosphorus and nitrogen can change the growth limitation. Nutrient enrichment has two main effects on natural vegetation: increase in biomass and increase in tissue nutrient concentration (van Duren and Pegtel 2000, Chapin, 1980, Vitousek et al 1995). Plant species generally react to the increased supply of the limiting nutrient, but not the non-limiting one, with higher biomass production (Verhoeven et al. 1996). Studies on nutrient limitation involving either a comparison across an existing soil nutrient gradient or experimental fertilization have shown that increased availability of a limiting nutrient, such as nitrogen $(\mathrm{N})$ or phosphorus $(\mathrm{P})$, can lead to higher leaf $\mathrm{N}$ or $\mathrm{P}$ concentrations (Chapin, 1980, Fisher et al., 2006, Vitousek et al. 1995). Despite the numerous fertilization experiments carried out, evidence regarding relationships between $\mathrm{N}: \mathrm{P}$ ratios and responses of plant populations to $\mathrm{N}$ or $\mathrm{P}$ addition is rather scarce (McKee et al. 2002, Feller 1995).

\subsection{Determining nutrient availability}

\subsubsection{Growth response}

According to von Liebig's Law of the minimum, the productivity of communities or species is governed by the availability of a single limiting resource, while other resources available in relative abundance are less important for plant growth. The productivity increase can be considered as a result of increased availabilities of the potentially growthlimiting nutrients: $\mathrm{N}$ and $\mathrm{P}$ (Olde Venterink et al. 2001). Also, the low concentration of a nutrient in plant biomass should reflect a low availability of the nutrient to the plant, and therefore indicates that additional supply of the nutrient might increase the plant's 
biomass production. If two or more nutrients are potentially limited, their availabilities relative to the other are likely to determine which of them is limiting (Koerselman and Meuleman 1996).

\subsubsection{Foliar N:P ratio}

If the concentration of an essential nutrient element in plant tissue drops below a level necessary for optimal growth, the plant is said to be deficient in that element. A deficiency may develop if the concentration of the element in the soil or substrate is low or if the element is present in chemical forms that render it unavailable for plant uptake. The assessment of nutrient availability from tissue analysis is based on the concept of critical concentration. Critical concentration is that concentration of a nutrient in the tissue just below the level needed to support optimal growth. Previous fertilization studies showed that less $\mathrm{N}$ and more $\mathrm{P}$ are taken up when supplemental quantities of both nutrients are made available to plants growing under background conditions of relatively low P supply and high $\mathrm{N}$ supply. In contrast, under conditions of relatively high $\mathrm{P}$ and low N supply, plants preferentially forage for and absorb N (Koerselman 1996). The N:P ratio should therefore determine which of the two nutrients is limiting, and only variables reflecting this relative availability would be indicative of the limiting nutrient. Tissue N:P ratio is considered a good indicator of nutrient limitation in wetland plants, providing a better indication of nutrient availability for plant growth than the concentration of either

nutrient separately (Koerselman and Meuleman 1996, Bedford et al. 1999, Gusewell et al. 2003). Based on a review of 40 field fertilization experiments in wetlands, Koerselman and Meuleman (1996) suggested biomass production of the vegetation is 
almost always limited by nitrogen if the molar N:P ratio of the aboveground biomass is low $(<14)$ and by phosphorus if the N:P ratio is high $(>16)$. They hypothesized that species with high N:P ratios would be enhanced by fertilization with $\mathrm{P}$, and populations with low $\mathrm{N}: \mathrm{P}$ ratio would be enhanced by fertilization with $\mathrm{N}$.

\subsubsection{Stable isotopes}

Since plants have the natural ability to discriminate against heavier stable isotopes, the abundance of stable isotopes, expressed as, for instance $\delta^{13} \mathrm{C}$ and $\delta^{15} \mathrm{~N}$, have been used as an indicator of nutrient availability (Novak et al. 1999; Mckee et al. 202; Wooller et al. 2003; Jones et al., 2004; Inglett et al., 2004; 2007; Wang et al. 2010). Studies have shown that plant discrimination against $\delta^{15} \mathrm{~N}$ becomes less with increasing $\mathrm{N}$ demand in an N-limited system (Schultze et al. 1994; Montoya and McCarthy 1995; Fry et al. 2000; McKee et al. 2002). Other experiments have shown that applying P-fertilizer to Plimited plants can increase $\mathrm{N}$ demand and lower the bias against ${ }^{15} \mathrm{~N}$ (Clarkson et al. 2005; Mckee et al. 2002).

As mentioned earlier, plant production is significantly influenced by nutrient availability. Through recent advances in the use of stable isotopes in ecosystem analyses and in plant physiology, the assessment of carbon isotope discrimination has become a valuable tool for the estimation of water use efficiency (Raven, 1992). The carbon isotope composition of plants reflects the ratio of internal to external carbon dioxide concentration in the leaf (Farquhar et al. 1982). Plants maintain an optimal relationship between leaf intercellular $\mathrm{CO}_{2}$-concentration and the concentration of $\mathrm{CO}_{2}$ in ambient air (Cowan, 1982). To 
maintain the internal and air carbon dioxide concentrations, stomatal conductance to $\mathrm{CO}_{2}$ and $\mathrm{H}_{2} \mathrm{O}$ is varied according to the assimilative demand. This is also reflected in the $\delta^{13} \mathrm{C}$ of plant organic matter. Since photosynthetic capacity is strongly influenced by the nutritional status of the plant (Pons et al, 1994), this also should have an effect on stomatal conductance.

In this study, I examine changes in isotopic ratios resulting from a shift from $\mathrm{P}$ to $\mathrm{N}$ limitation or vice versa after nutrient treatment, where $\delta^{13} \mathrm{C}$ may be useful to assess the photosynthetic changes resulting from increased growth rates and $\delta^{15} \mathrm{~N}$ could indicate increased $\mathrm{N}$ demand or decreased $\mathrm{N}$ availability under condition of $\mathrm{N}$ limitation or $\mathrm{P}$ addition. 


\section{OBJECTIVES AND HYPOTHESIS}

\subsection{Objectives}

Tree island development through soil accretion depends greatly on tree productivity, which in turn varies with soil nutrient availability. Biomass production and nutrient dynamics on the islands may be affected by island type (peat or limestone). The balance of $\mathrm{N}$ and $\mathrm{P}$ in the tissues of different species may change along the hydrologic gradient and during stand development, in conjunction with changes in nutrient availability in the soil. This study determined whether nutrient limitation is an important factor in the development of tree islands, and will help in understanding $\mathrm{N}$ and $\mathrm{P}$ limitation to tree growth across a hydrological gradient and in contrasting soil environments. The goals of this research are to determine the tree response when conditions limiting optimal growth for the species are improved by fertilization and to determine the nature of nutrient limitation in tree species growing on limestone and peat islands.

Hypothesis I: Trees on peat islands will respond strongly only to experimental increases in the supply of $P$; whereas trees on limestone islands will respond to increases in the supply of both $N$ and $P$.

Edaphic factors influence the retention of nutrients, especially in oligotrophic wetlands like the Everglades (Ross et al, 2006). The subtropical peatland of the Florida Everglades is characterized by high soil $\mathrm{N}$ and a high $\mathrm{N}: \mathrm{P}$ ratio in the parent material (Koch and 
Reddy, 1992). Since peat islands were built solely from organic surface sediment and the lack of nutrient inputs from mineral sediment deposition, low P content is expected.

Both $\mathrm{N}$ - and P-availability in limestone islands are expected to be very low as only a thin a layer of soil exists. Organic soil directly overlays the limestone substrate; P-adsorption by calcium carbonate is a strong possibility. P-availability in limestone substrates can be also very low due to high $\mathrm{pH}(>7.5)$ soils. Therefore, trees on limestone islands are expected to respond to both $\mathrm{N}$ - and P-treatment.

Hypothesis II: Fertilization to increase the availability of $N$ or $P$ to plants will be reflected in their foliar N:P ratios. Similarly, $P$ addition will lead to increased $\delta^{15} N$.

Plants take up relatively more $\mathrm{P}$ than $\mathrm{N}$ under conditions of low $\mathrm{N}$ and high $\mathrm{P}$ supply (Koerselman 1992). Due to the luxury consumption of $\mathrm{P}$, the N:P ratio in plant tissue will be relatively low. In contrast, there will be a higher N:P ratio in plant tissue under conditions of relatively high $\mathrm{N}$ and low $\mathrm{P}$ supply. Thus, plants have a critical N:P ratio that can be used to determine whether growth of the species is N-limited or P-limited (Koerselman and Meuleman 1996). In addition, it is hypothesized that with P addition, increasing $\mathrm{N}$ demand would decrease plant discrimination against ${ }^{15} \mathrm{~N}$. Under $\mathrm{N}$-limited conditions, plants may also utilize available $\mathrm{N}$ pools completely, thereby reducing the potential discrimination against heavier isotopes (Inglett and Reddy, 2004). If trees are Plimited, leaf $\delta^{15} \mathrm{~N}$ is expected to increase with P addition as exhibited in several wetland studies (Inglett et al. 2006; Inglett et al. 2007). 
Hypothesis III: Leaf N:P ratios are expected to be relatively high at the base of the islands and low at the highest elevation of the islands.

Soil P concentration increases along an elevation gradient from marsh to tree islands in the Everglades. Since the amount of $\mathrm{N}$ in tree islands in Everglades is positively correlated with organic matter content and negatively correlated with calcium carbonate, soil $\mathrm{N}$ concentration is expected to decrease moving upslope towards shorter hydroperiods or shallower water depths. This is because relatively dry condition in tree island heads can accelerate leaf litter decomposition and the development of deep root systems; in contrast, decomposition rates should be slower in the flooding fringes of the islands (Jayachandran et al. 2004). Thus, I expect that $\mathrm{N}$-limiting conditions are found on upland portions of island whereas P-limiting conditions are found at the base of the island.

Hypothesis IV: Leaf $\delta^{13} \mathrm{C}$ is expected to be lower with increasing relative elevation (RE) in tree islands.

In LILA, stress gradients (flooding, and nutrients) may occur across tree islands where tree growth increases with RE (Stofella et al., 2010). Various authors reported a negative correlation between leaf carbon isotope $\left(\delta^{13} \mathrm{C}\right)$ and tree height (Mckee et al. 2002; Lin and Sternberg 1992) and attributed the higher $\delta^{13} \mathrm{C}$ values in short trees to elevated stress and consequent effects on stomatal conductance. In a similar way, I am expecting a decreasing pattern of $\delta^{13} \mathrm{C}$ with increase in $\mathrm{RE}$ as trees on the base of the islands experience more flooding and nutrient (especially P) stress. 


\section{METHODS AND MATERIALS}

\subsection{Study Area}

The study took place from July 2009 to September 2010 at the Loxahatchee Impoundment Landscape Assessment (LILA) site at the Arthur R. Marshall Loxahatchee National Wildlife Refuge in Boynton Beach, Florida. The LILA facility (lat 26 ${ }^{\circ} 17.999^{\prime} \mathrm{N}$, long $80^{\circ} 13.979^{\prime} \mathrm{W}$ ) was constructed in $2002-2003$ through a partnership between South Florida Water Management District, U. S. Army Corps of Engineers and U.S. Fish and Wildlife Service. It serves as a landscape-scale physical model of the Everglades that allows researchers to conduct experiments in a semi-controlled environment before applying results to the 688 thousand-hectare Everglades ecosystem. It consists of four identical 8-hectare macrocosms (M1-4) (Figure 2). In each macrocosm, 2 types of tree islands were constructed: peat and limestone. Limestone tree islands represent fixed islands that form on limestone outcrops in all parts of the Everglades marsh. Peat tree islands represent pop-up or battery islands that form on floating chunks of peat or vegetation rafts, or peat-based islands that may form on flat bedrock. Battery islands are most common in the northern parts of Everglades (Wetzel 2002). Each 71 $\mathrm{m} \times 43 \mathrm{~m}$ sized island had side slope of $16: 1$ along the long north and south sides, and 12:1 along the shorter east and west sides. Maximum elevation of the island was $0.90 \mathrm{~m}$ above the surrounding slough surface. Peat islands were built from organic surface sediment while limestone islands were constructed above a base of locally mined limestone gravel occupying the $49 \mathrm{~m} \times 14 \mathrm{~m}$ central portion of the island; the limestone core was covered with $0.3 \mathrm{~m}$ of peat soil ( Figure 3) (van der Valk et al. 2008, Stoffella et 
al. 2010). Since, sediments at the fringes of the limestone islands, beyond the central 49 m X $14 \mathrm{~m}$, were similar in condition to the peat islands, tree samples from these regions were considered to be peat-based for the purpose of this study.

About 5,736 seedlings of 10 tree species of varying flood tolerance were planted on the eight islands during March of 2006 and 2007. Macrocosms M1 and M4 were planted in 2006 and M2 and M3 were planted in 2007. Each island was divided into four quadrants, which were planted at spacings of 1.0, 1.67, 2.33 and $3.0 \mathrm{~m}$. To ensure representative placement in all hydrological environments, eight species common to Everglades' tree islands near to LILA site were randomly assigned to planting locations within the relatively high, interior $18 \mathrm{~m} \times 10 \mathrm{~m}$ of each quadrant, and the lower surrounding areas separately. The planting arrangement called for 89 trees of each species per island. Planting stock was from local seed sources, grown for about 9-months in 1-gallon (3.78 liter) pots at a local commercial nursery prior to outplanting in LILA.

\subsection{Experimental design}

LILA's M2 and M3 macrocosms provided the setting for the experiment (Figure 2). The M2 and M3 macrocosms include two islands each, one with a peat substrate and one with a limestone substrate. Eighteen trees of each species, Annona glabra and Chrysobalanus icaco, were selected randomly from each island for a total of 36 trees per island, 72 trees per microcosm, and 144 trees overall. Each tree received one of three nutrient treatments: Nitrogen, Phosphorus, or no nutrient enrichment. Therefore, 6 replicates were provided for each combination (species-treatment-substrate type) in each island. 
All the sample trees were selected from less dense plots $(3 \mathrm{~m}, 2.33 \mathrm{~m}$ and $1.67 \mathrm{~m})$ to avoid competition among individual trees.

A total of 108 trees were fertilized with one of the two nutrient enrichments (excluding the 36 control trees) for a year from July 2009 to June 2010. The N enrichment was added in the form of urea (45-0-0). The $\mathrm{P}$ enrichment was added in the form of orthophosphate, $\mathrm{Na}_{2} \mathrm{HPO}_{4},(0-45-0)$. Nutrient enrichments were applied as a solution of dry pellet fertilizer dissolved in water. An allometric biomass equation was used to calculate total amount of biomass increase annually in each species population. Since data on tissue nutrient concentration $\left(\mathrm{mgg}^{-1}\right)$ was available for each species (M. Ross, unpublished data), I used that nutrient data as reference to calculate the total amount of nutrient that an individual will accumulate annually for each species. At the end of the experiment, the cumulative amount of $\mathrm{N}$ and $\mathrm{P}$ applied over the course of the year was three times the amount of that nutrient that one individual normally incorporates into live tissue during an annual cycle (about $72 \mathrm{~g}$ of $\mathrm{N}$ or $\mathrm{P}$ per tree).

A total of six doses of $\mathrm{N}, \mathrm{P}$ or water (controls) were applied to each tree. Each $\mathrm{P}$ treatment tree received about $500 \mathrm{ml}$ nutrient solution, each $\mathrm{N}$ treatment tree received about $300 \mathrm{ml}$ of nutrient solutions and each control tree received $300 \mathrm{ml}$ of tap water. To apply nutrient enrichments, two $30 \mathrm{~cm}$ deep holes were cored into the substrate within the canopy shadow of each tree (Figure 4). A cap with holes was fixed to the bottom of the $1.3 \mathrm{~m}$ long PVC pipe ( 0.75 inch diameter) to release of the nutrient solution into the surrounding substrate. The pipe was inserted into the hole, leaving 1.0 meter exposed 
above the substrate. The top of the pipe was capped after nutrient delivery. Holes were cored and pipes installed for all trees including control trees following identical procedures to ensure homogeneous experimental conditions.

Total height, crown length, crown volume, and basal diameter of each tree were measured at the beginning and end of the experiment. The final measurements were taken 5 months after the last nutrient dose to ensure that plants had enough time to respond after nutrient application. To analyze leaf nutrient concentration, 5-7 leaves from each tree were harvested at the end of the experiment. All samples were brought to the laboratory immediately for analysis.

\subsection{Hydrology}

A continuous record of surface water level was available from the LILA facility over the experiment period. Daily surface water level was monitored at the western (head) and eastern ends of each macrocosm. Surface water level at each tree island was estimated from a linear interpolation between water levels at the both ends of the macrocosm.

Tree island elevations were established by 1) surveying with an auto-level $(3 \mathrm{~mm}$ accuracy) from vertical control benchmarks established by the SFWMD in each macrocosm to a temporary benchmark established in the center of each island, 2) surveying from the temporary benchmark to the base of approximately 150 newly planted trees of known horizontal location, 3) developing a contour plot of elevation from these data through ARC-GIS 9.2, and 4) applying the Spatial Analyst Extension in ARC-GIS to 
determine an elevation of each tree. Relative elevation (RE) of each tree was calculated as the position of each tree above or below the mean tree island surface water over the experiment period. For example, $20 \mathrm{~cm}$ RE means the soil surface at the tree base was located $20 \mathrm{~cm}$ above the mean surface water, while $-20 \mathrm{~cm}$ RE was $20 \mathrm{~cm}$ below mean surface water.

Soil samples were collected from 0-10 cm depth under the sample trees at the end of the experiment. Nine trees of each species (A. glabra and C. icaco) were selected randomly from each island for a total of 18 trees per island, 36 trees per substratum type (peat or limestone). Since each tree received one of three nutrient treatments: Nitrogen $(\mathrm{N})$, Phosphorus (P), and control, each nutrient treatment had three replicates for each species per island.

\subsection{Laboratory analysis}

Once in the laboratory, leaf samples were dried at $65^{\circ} \mathrm{C}$ until a constant weight was obtained and then ground to a fine powder. A 1-2 mg subsample was placed in a tin capsule. Samples were combusted in an elemental analyzer (Carlo Erba) coupled to an isotope ratio mass spectrometer (IRMS Delta Plus, Finnigan Mat, San Jose, CA, USA) operating in a continuous flow mode. From these analyses, both isotope ratio $\left(\delta^{13} \mathrm{C} ; \delta^{15} \mathrm{~N}\right)$ and elemental content $(\% \mathrm{C} ; \% \mathrm{~N})$ were obtained for carbon and nitrogen. Data are expressed in "delta" notation $\left(\delta{ }^{13} \mathrm{C}\right.$ and $\left.\delta{ }^{15} \mathrm{~N}\right)$ as:

$$
\delta=\left[\left(\mathrm{R}_{\text {sample }} / \mathrm{R}_{\text {standard }}\right)-1\right] \mathrm{X} 1000 \text { where, } \mathrm{R}_{\text {sample }} \text { and } \mathrm{R}_{\text {standard }} \text { are the ratio }{ }^{13} \mathrm{C}:{ }^{12} \mathrm{C}
$$

or the ratio ${ }^{15} \mathrm{~N}:{ }^{14} \mathrm{~N}$ of the sample and standard, respectively, and the standards for carbon 
and nitrogen are PDB (Pee Dee Belemnite) and air, respectively. All results were normalized to $\mathrm{mg} / \mathrm{g}$ dry weight concentrations.

Total phosphorus was analyzed colorimetrically according to the standard method for orthophosphate P (EPA method 365.1). Sample digestion methods were based on the procedure outlined by Solórzano and Sharp (1980). Oven-dried samples were oxidized through dry combustion, and all phosphorus-containing compounds were hydrolyzed to soluble reactive phosphorus (SRP) using magnesium sulfate (MgSO4) and hydrochloric acid $(\mathrm{HCl})$. Products were stored a $4^{\circ} \mathrm{C}$ and analyzed within 48 hours of digestion.

The N:P ratios can be expressed either as mass ratios $(\mathrm{g} \mathrm{N} / \mathrm{g} \mathrm{P})$ or as atomic ratios (mol $\mathrm{N} / \mathrm{mol} \mathrm{P}$ ), which differ by a factor of 2.21 . Since most literature in ecology uses mass N:P ratios, I also followed this convention.

\subsection{Statistical analysis}

The effect of nutrient treatments along with substrate types and relative elevation on tree growth and leaf nutrient concentration were analyzed for both species for one year. A two-way ANOVA was performed to examine the effects of nutrient treatment and tree island type (limestone vs peat) on leaf nutrient concentrations $(\mathrm{N}, \mathrm{P}, \mathrm{N}: \mathrm{P}, \delta 13 \mathrm{C}$ and $\delta 15 N)$ and growth response for each species. Two-way ANOVA was also performed on soil TN, TP, and N:P to test for an effect of substrate types and nutrient treatments for each species. A Linear Regression model was used to examine the effects of relative elevation on species growth response ( $\Delta$ height growth) and all the tissue nutrient 
measurement variables (TN, TP, N:P, $\delta^{13} \mathrm{C}$ and $\delta^{15} \mathrm{~N}$ ). Multiple comparisons were only performed if two-way ANOVA results showed significant effect on the response variable. Results were considered statistically significant at the p-value less than 0.05 level. Prior to using ANOVA, assumptions of normality and homogeneity of variance were tested by the Shapiro-Wilkes and Levene's tests, respectively. All analyses were done in STATISTICA (Version 7.1, StatSoft Inc., Tulsa, OK, USA). 


\section{RESULTS}

\subsection{Nutrient treatment effect on plant growth}

The two species differed in their height responses to the nutrient treatments. A. glabra height growth increased significantly in response to $\mathrm{P}$ fertilization on both substrate types (Figure 5). Substrate type had no effect on A. glabra height growth and no interaction between substrate and nutrient treatment was detected (Appendix I). In contrast, C. icaco height growth did not respond to nutrient treatment at all but did exhibit a significant response to substrate type; trees grew higher on limestone islands than peat islands regardless of nutrient treatment (no significant nutrient $\mathrm{x}$ substrate interaction) (Appendix I, Figure 6).

\subsection{Soil nutrient analyses}

The two-way ANOVA results showed that nutrient treatment did not affect soil TN, TP, $\mathrm{N}: \mathrm{P}$ under $A$. glabra (Appendix II). In this species, a substrate effect on soil TP was observed, with soils under trees growing on peat substrate having significantly higher TP than those on limestone substratum (Figure 7). In contrast, nutrient treatment did affect soil TP under C. icaco, and multiple comparison tests revealed that P-fertilized trees had significantly higher soil TP than Control or N-treated trees (Appendix II; Figure 8). Similarly, a significant nutrient treatment effect was observed on soil N:P ratio in this species, as soils collected from $\mathrm{N}$-fertilized trees were found to have significantly higher $\mathrm{N}: \mathrm{P}$ ratios than those from control and P-fertilized trees (Appendix II; Figure 9). No 
substrate effects were observed under C. icaco trees, and no interaction between substrate and nutrient treatments was observed (Appendix II).

\subsection{Foliar nutrient concentration and leaf N:P ratios}

Neither species exhibited a statistically significant effect of nutrient treatment on leaf TN (see Appendix I). However, a substrate effect on leaf TN was detected for both species; leaf $\mathrm{TN}$ was found to be significantly higher in trees from limestone islands than in peat island trees (Figures 10 and 11). No significant interaction between substrate and nutrient treatment was detected for either species (Appendix I).

In both species, leaf TP increased significantly in response to $\mathrm{P}$ fertilization but there was almost no change in leaf TP with $\mathrm{N}$-fertilization (see Appendix I). Furthermore, multiple comparisons test revealed that P-fertilized trees had significantly higher TP than Control and N-treated trees in both species (Figures 12 and 13). Substrate effects were not observed for either species. However, there was a significant interaction (substrate $\mathrm{x}$ nutrient treatments) in C. icaco ( see Appendix I).

Nutrient treatment effects on leaf N:P ratios were observed in both species (Appendix I) as P-fertilized trees had significantly lower N:P ratios than those from control and Nfertilized ones (Figures 14 and15). Furthermore, leaf N:P in N-fertilized and Control trees were almost always observed to be greater than 16 (considered to be a critical value for P-limitation), while P-fertilized trees had N:P ratios $<16$ in both species (Figures 16 and

17). Substrate effects on leaf N:P was not detected for either species. No interaction 
(substrate $\mathrm{x}$ nutrient treatment) effect on leaf $\mathrm{N}: \mathrm{P}$ was detected in A. glabra, but a significant interaction (substrate $\mathrm{x}$ nutrient treatment) was detected in C. icaco (Appendix I).

A significant nutrient treatment effect on leaf $\delta^{15} \mathrm{~N}$ was detected in both species (Appendix I). Post-hoc test further revealed that there was a significant difference between Control and $\mathrm{N}$-fertilized trees of both species, but leaf $\delta^{15} \mathrm{~N}$ in P-treated trees was not statistically different than either of the other treatments (Figures 18 and 19). In $A$. glabra, $\delta^{15} \mathrm{~N}$ increased by $44.8 \%$ and $92.8 \%$ above Control trees in $\mathrm{P}$ and $\mathrm{N}$ treatments, respectively; in C. icaco, the analogous increase were $68.1 \%$ and $78.6 \%$. No substrate or interaction (substrate x nutrient) effects were detected in either species (Appendix I).

The two species differed in how leaf $\delta^{13} \mathrm{C}$ responded to the nutrient treatments. A. glabra leaf $\delta^{13} \mathrm{C}$ increased significantly in response to P-fertilization but substrate type had no effect at all (Appendix I, Figures 20). In contrast, neither nutrient treatment nor substrate type affected $\delta^{13} \mathrm{C}$ in $C$. icaco. Interaction effects on leaf $\delta^{13} \mathrm{C}$ were non-significant in both species (Appendix I).

\subsection{Responses with nutrient treatment along hydrological gradient}

The effect of RE on tree growth was found to be similar in both species, and across all nutrient treatments. Growth showed a significant positive response to RE in both unfertilized trees and P-fertilized trees in both species, as they grew taller with a decrease in flooding duration and depth (Figures 21 and 22). However, in N-fertilized trees, the 
effect of RE was only observed in C. icaco; the response of A. glabra, while positive, was not significant at $\mathrm{P}<0.05$. Among Control and $\mathrm{N}$-fertilized trees of both species, leaf $\mathrm{N}: \mathrm{P}$ ratios were unaffected by RE. However, in P-fertilized trees, leaf N:P ratio was found to increase significantly with increasing RE in both species (Figures 23 and 24).

Carbon isotopic compositions of both A. glabra and C. icaco changed slightly along the RE gradient. Leaf $\delta^{13} \mathrm{C}$ ranged from -29.5 to -26.9 for $A$. glabra, and -31.41 to -28.64 for C. icaco. In A. glabra, $\delta^{13} \mathrm{C}$ was found to increase significantly with $\mathrm{RE}$ in P-fertilized trees but not in Control or N-fertilized individuals (Figure 25). In contrast, C. icaco Control trees showed a significant positive correlation between leaf $\delta^{13} \mathrm{C}$ and RE, while trees fertilized with either nutrient showed no such response (Figure 26). Relationships between $\mathrm{N}: \mathrm{P}$ ratio and $\delta^{13} \mathrm{C}$ showed no significant patterns for Control and $\mathrm{N}$-treated in either species, but P-fertilized A. glabra trees exhibited a positive correlation between $\mathrm{N}: \mathrm{P}$ ratios and $\delta^{13} \mathrm{C}$ (Figure 27 and 28). An overall positive relationship between growth response and $\delta^{13} \mathrm{C}$ was observed for both species regardless of nutrient treatment (Figures 29 and 30). 


\section{DISCUSSION}

\subsection{Plant response to nutrient treatment}

Fertilization experiments are considered the best way to determine which nutrient limits either an individual plant population or a community type (Bedford et. al, 1999). If species are nutrient limited, they would be expected to respond to fertilization with increases in tissue nutrient concentration, growth or both (Tessier and Raynal, 2003). A highly significant P-treatment effect on leaf TP, indicative of P limitation, was found in both species tested in this experiment (Figures 12 and 13). In A. glabra the increase in leaf $\mathrm{P}$ was accompanied by a positive growth response (Figure 5). In contrast, neither $A$. glabra nor C. icaco responded to N-fertilization on either of the substrate type, nor were their leaf nutrient concentrations or N:P ratios affected (Appendix I). Therefore, the results suggest that the growth of both species (C. icaco, A. glabra) at the LILA tree islands were limited by $\mathrm{P}$ and not by $\mathrm{N}$ on both limestone and peat substrates. Similar positive species' responses have been demonstrated in other fertilization experiments. For example, fertilization experiments performed in mangrove forests in Belize showed that tree growth was significantly increased in response to limiting P (Feller 1995; Feller et al., 1999; Feller et al., 2002; McKee et al., 2002; Lovelock et al., 2004). Shaver and Chapin (1980) did similar experiment on tundra species (both shrubs and herbaceous) and found a consistent growth response to limited nutrient addition. Several studies reported P-limited growth and biomass accumulation in seagrass species as $\mathrm{P}$ additions resulted in increased leaf $\mathrm{P}$ content, reduced N:P ratios, and enhanced shoot growth (Perez et al. 1991; Fourqurean and Zieman 1992, Ferdie and Fourqurean 2004). 
However, the interspecific difference in growth response to $\mathrm{P}$ fertilization may indicate that not all species respond to nutrient addition in a similar way (Vitousek et al., 1993; Sterner and Elser, 2002). Slow-growing plants from nutrient deficient sites may not respond to short term fertilization with an increase in growth (Chapin III, 1980, Vitousek et al., 1993); instead they often accumulate nutrients when they are more readily available, to be used during subsequent periods of stress (Grime 1977). Tessier and Raynal (2003) found similar results for six Catskill understory species. None of the species responded to $\mathrm{N}$-addition while P-addition caused all species to increase in Pconcentration but only one to increase in biomass. Troxler et al., (2005) reported that $C$. icaco was the most efficient user of $\mathrm{N}$ and $\mathrm{P}$ relative to other co-occurring species in Everglades tree islands. Therefore, it is likely that observed difference in the growth response of A. glabra and C. icaco could be a result of slight differences in their shortterm growth strategy of response to limiting nutrient. However, this conclusion needs to be further tested with greenhouse and long-term fertilization experiments.

\subsection{Nutrient availability and substrate effect}

The effects of substrate type on soil nutrient content were negligible in this study, however, the growth response in C. icaco and leaf TN in both species were significantly higher in limestone islands for both species regardless of nutrient treatments (Appendix I, Figures 10 and 11). These contradictory results raise a question regarding nutrient availability on each substrate. For many years, plant nutritionists and biogeochemists have been concerned with developing more precise methods to evaluate total nutrient availability for plant growth, particularly in sites where very low soil concentrations of 
elements exists. Predictions of nutrient availability based on analysis of the total amount of an element (TN or TP) in a soil sample can sometimes be misleading, as several factors complicate this approach. The main problem is in distinguishing between available and non-available forms of element. Soil chemical extractions are more difficult to interpret than leaf concentration (Tanner et al., 1998). Therefore, the higher leaf TN observed on limestone islands in both species indicates that $\mathrm{N}$ availability was slightly lower in the peat substrate. One potential reason could be the differences in water retention capacity between substrates. In tree islands that have a higher surface than the surrounding landscape, peat substrates can generally maintain water levels several centimeters above the surrounding surface water due to the capacity of their organic matter-rich soil to hold more water than most mineral soils (Mitsch and Gosselink 2007). Conversely, limestone islands have little capacity to retain water and generally drain rapidly, thereby maintaining a drier condition within the rooting zone of the plants (Stoffella et al., 2010). For instance, Sullivan et al. (2010) observed that the water table was lower on limestone substrate islands at the LILA site than on peat substrate, and responded more abruptly to groundwater drawdown. The relatively anoxic environment that may develop on peat soil may also slow down the decomposition process and consequently reduce nutrient availability for plants. In contrast, the drier condition that exists on limestone substrate may accelerate decomposition processes, making nutrients, particularly N, more easily available for plants (Shure, 1981).

A substrate effect on growth response was detected only in C. icaco, in which higher growth was observed on limestone substrate (Figure 6). Since flooding stress is one of the 
major factors that determine the survival and growth of plant species, differences in flood tolerance ability among species may easily be expressed (see Stoffella et al., 2010). A. glabra has been consistently ranked among the most flood tolerant Everglades tree island species, while C. icaco appears to be somewhat less flood tolerant (Armentano et al. 2002; Gunderson et al. 1988; Jones et al. 2006; van der Valk et al. 2007). Therefore, the lower growth response exhibited by $C$. icaco in peat substrate could be because of flooding stress and high soil moisture condition. The edges of all islands contain similar soil and hydrology to the peat islands, so the substrate effect could only be tested on the centers of the islands at high elevations underlain by limerock (Figure 3).

\subsection{Critical N:P ratio and nutrient limitation}

Recently the nutrient ratios of plant tissue have become widely used as an alternative approach for the analysis of nutrient limitation (Gusewell 2004), especially in comparison to more laborious and time consuming fertilization experiments (Verhoeven et al. 1996; Bedford et al. 1999; Olde Venterink 2000, Gusell, 2004). Koerselman and Meuleman (1996) reviewed data on fertilization studies in a variety of European freshwater wetlands and proposed the following critical N:P mass ratios: below 14 indicating $\mathrm{N}$ limitation, above 16 indicating P limitation and between 14 and 16 indicating co-limitation. Gusewell et al. (2003) suggested that biomass N:P ratios do reflect the relative availability of $\mathrm{N}$ and $\mathrm{P}$ to plants and may indicate the degree of $\mathrm{N}$ or $\mathrm{P}$ deficiency experienced by a plant population even more reliably than fertilization experiment. Bedford et al. (1999) reviewed extensive literature and analyses of data on nutrient stoichiometry in plant tissues and surface soils to draw conclusions about nutrient 
limitation in temperate North American wetlands. They found that marshes dominated by vascular herbaceous species were predominantly $\mathrm{N}$ limited, while other wetland types and growth forms were P-limited on the basis of N:P ratios in live tissues. Güsewell and Koerselman, (2002) again reviewed data from field fertilization experiments, and suggested lowering of the critical N:P ratios for N-limitation to 13:1. Although there has been wide variation in the literature on critical $\mathrm{N}: \mathrm{P}$ ratios for $\mathrm{N}$ or $\mathrm{P}$ limitation of vegetation growth, ranging from 7 to 16 for $\mathrm{N}$ limitation, and 12 to 29 for $\mathrm{P}$ (Appendix III), the threshold values given by Koerselman and Meuleman (1996) have been broadly used for various growth forms. Since, their critical N:P ratios were based on herbaceous vegetation, the generality of these values has been already questioned by some researchers ( e.g., Tessier and Raynal 2003; Soudzilovskaia 2005). There is clearly a need for experimental testing to define accurately the critical N:P ratios for tree island species to use this tool for management and monitoring purposes. The present study can provide valuable information on critical foliar N:P ratio for tree island species on the basis of a fertilization experiments. Figures 16 and 17 clearly show that critical N:P ratios for $A$. glabra and C. icaco exist, at least with an upper critical value 16. In both species, leaf $\mathrm{N}: \mathrm{P}$ ratio was $>16$ in Control trees which gives an indication of $\mathrm{P}$ limitation on the islands. Similarly, Saha et al. (2009) also reported high mean leaf N:P ratio for hammock (45) and pineland (42) species in the Everglades. Richardson et al., (1999) also reported leaf N: P ratios of 70-84 in sawgrass (Cladium jamaicense) from Everglades prairies.

The indication of P-limitation on Control trees of both species due to high N:P ratios $(>16)$ is further supported by the significant decrease in leaf $\mathrm{N}: \mathrm{P}$ ratios with $\mathrm{P}$ enrichment 
i.e., to below 16, while remaining the same with $\mathrm{N}$-enrichment i.e N:P>16. This implies that trees were first limited by P, and when the limiting nutrient was supplied in excess, plants became limited by N. According to von Liebig's law of minimum, which states that individual plant species can be characterized by a fixed order in their nutrient requirements, only one nutrient actually limits growth at any one time. If there is a continuing application of the initially-limiting nutrient, the result is that growth limitation eventually switches to another nutrient.

\subsection{Nutrient treatment effect on leaf $\delta 15 \mathrm{~N}$}

The potential for limitation to switch from one nutrient to another is corroborated by nitrogen isotope analyses in this study. With $\mathrm{P}$ addition, phosphorus was expected to become easily available, inducing plants to increase their $\delta^{15} \mathrm{~N}$ as the result of increased $\mathrm{N}$ demand and reduced discrimination against the heavier isotope during $\mathrm{N}$ uptake (Figures 18 and 19). The trend in the data did support my expectation that leaf $\delta^{15} \mathrm{~N}$ would increase with P-treatment relative to Control plants (Figures 18 and 19), though the difference did not reach statistical significance. Similar trends have also been reported in other studies (Mckee et al. 2002, Evans 2001, Clarkson et al. 2005, Inglett et al 2007) and Clarkson et al. (2005) proposed that the increased $\delta^{15} \mathrm{~N}$ was a result of a decreased fractionation by plants as $\mathrm{N}$ demand increased, not because of the change in the $\delta^{15} \mathrm{~N}$ of the $\mathrm{N}$ source. For example, Mckee et al. (2002) and Clarkson et al. (2005) reported that $\delta^{15} \mathrm{~N}$ was increased with $\mathrm{P}$ enrichment in P-limited system in mangroves and New Zealand bog species, respectively. In my study, the significant higher $\delta^{15} \mathrm{~N}$ observed in $\mathrm{N}$-treated plants could also be a result of Urea (high $\delta^{15} \mathrm{~N}$ ). Several studies reported high 
$\delta^{15} \mathrm{~N}$ in commercial fertilizers (e.g., Flipse and Bonner 1985, Gautam and Iqbal 2010, Hubner 1986).

\subsection{Limitations of using N:P ratio}

An important limitation to the use of critical N:P ratios to assess nutrient limitation is that it is only effective if either N or P is limiting (Aerts and Chapin 2000, Koerselman and Meuleman, 1996). Other factors could and often do could also limit plant growth (e.g., light, water, temperature, and other nutrients particularly potassium). Since sampled trees were selected from low-density plots, i.e. all trees were spaced at least 1.67 meters apart on center; it is unlikely that light limited their growth. Temperature was also probably not an issue in South Florida's subtropical environment.

Since N:P threshold values described by Koerselman and Mauleman were derived exclusively from marsh vegetation, from harvesting whole aboveground biomass from a community in a wide range of wetlands, some authors (e.g., Aerts and Chapin 2000) have cautioned against using N:P ratios of individual species rather than of the community because of inherent interspecific variation in leaf nutrient chemistry (Daoust and Childers, 1999). However, community productivity is always controlled by dominant species (Grime, 1998), and net-primary production relates to community level N:P ratios. Tree island community level N:P ratio may also be driven by the N:P ratios of the dominant species and C. icaco and A. glabra are two of the dominant woody species in tree islands. However, it would be better to further test these results with other species. 


\subsection{Background nutrient availability and nutrient application}

In this experiment, small doses of $\mathrm{N}$ or $\mathrm{P}$ fertilizers were directly added into the soil near the base of individual trees through pores in PVC conduit $30 \mathrm{~cm}$ below the soil surface, which allowed the slow release of fertilizer directly onto the plant roots. I applied fertilizers for one year so that the plants received nutrient addition continuously during the experimental period. A nutrient treatment effect on soil TP was observed in both species (though the p-value for A. glabra was marginal at 0.06, see Appendix II). Soil TP under P-fertilized trees was increased by $109 \%$ and $102 \%$ in C. icaco and A. glabra, respectively. Increased soil TP concentration around treated trees indicates that total nutrient content in soil was affected by fertilization (Figure 3 and 4). However, no significant nutrient treatment effect was observed from $\mathrm{N}$-treatment for either species (Appendix II). The soil TN from N-fertilized trees was increased by $37.2 \%$ and $3.2 \%$ in C. icaco and A. glabra, respectively. The difference in nutrient effect on soil $\mathrm{N}$ and $\mathrm{P}$ could result from a difference in their retention time in soil. Nitrogen is less likely to persist in a soil for a long time as it can be lost through denitrification (in anoxic environments) and cycled into the gaseous phase. The phosphorus cycle does not include such a gaseous phase, and phosphorus has a strong affinity towards limestone substrate, thus it is relatively immobile in limestone-derived soils. Ferdie and Fourqurean (2004) found similar results in south Florida estuaries in which, $49-82 \%$ of $\mathrm{P}$ added to P-limited seagrass meadows was retained for at least a year, while less than $10 \%$ of added $\mathrm{N}$ was retained over the same time period in $\mathrm{N}$-limited seagrass beds. 
In this study, phosphorous was applied in the form of sodium biphosphate $\left(\mathrm{Na}_{2} \mathrm{HPO}_{4}\right)$. The additional sodium to P-treated trees likely did not affect tree response, as the relative addition of sodium was low (personal conversation with Dr. Leonard Scinto). Furthermore, the effect of neighboring individuals subjected to a different treatment was minimized by the experiment design, which employed a random selection of trees from low density plots ( $3 \mathrm{~m}, 2.33 \mathrm{~m}$, and $1.67 \mathrm{~m}$ spacing), where canopy overlap was minimal.

\subsection{Nutrient limitation along the hydrological gradient}

Previous studies from tree islands have demonstrated that moisture has a significant effect on nutrient availability (Hanan and Ross 2010; Jayachandran et al., 2004, Ross et al, 2006). Ross et al. 2006 reported a decreasing trend in leaf N:P ratios from marsh through Hardwood Hammock, suggesting that phosphorus limitation of growth dissipates with decreasing flooding frequency in Everglades. The results in this study are not consistent with those studies from Everglades tree islands, as no significant change in leaf $\mathrm{N}: \mathrm{P}$ was observed along RE gradient in Control trees within either species (Figures 23 and 24). However, P-treated trees of both species (but not Control and N-treated trees) exhibited a positive correlation between RE and leaf N:P (Figures 23 and 24); thus, maximum $\mathrm{N}: \mathrm{P}$ ratio was found at the highest elevation and the lowest $\mathrm{N}: \mathrm{P}$ was found at lowest elevation when P-availability was augmented. In contrast, growth response patterns of Control and N-treated trees also showed a positive correlation with RE but leaf N:P ratio was unaffected by elevation. Since P-treated trees had N:P ratio lower than 16 in both species, tree on lower elevation (flooded zone) are likely to be $\mathrm{N}$ limited (Figure 23 and 24) after P-addition. Flood-related stress such as anoxia can negatively 
affect plant growth and inhibit nutrient uptake (Lin and Sternberg, 2007). Therefore, the low N:P corresponding to low growth response to P-treatment at lower elevation could be due to flooding stress.

\subsection{Effect of nutrient treatment on leaf $\delta^{13} \mathrm{C}$}

Carbon-stable isotopic ratio of plant tissues is often used as an indicator of gas exchange (Inglett and Reddy, 2006). In general, stomatal closure and reduced carbon isotope discrimination are stress responses and have been demonstrated in plants exposed to stress (Guy and Wample, 1984). Physiological stress can limit $\mathrm{CO}_{2}$ supply for photosynthesis and thus lower discrimination against ${ }^{13} \mathrm{C}$ and reduced productivity (McKee et al, 2002). Generally enzymatic discrimination against ${ }^{13} \mathrm{C}$ is at maximum when stomata are more open or rates of photosynthesis are low. In contrast, less discrimination against ${ }^{13} \mathrm{C}$ was found when plants use internal $\mathrm{CO}_{2}$ more completely when stomata are closed or photosynthesis is high (Inglett and Reddy, 2006). The significant pattern observed in $\delta^{13} \mathrm{C}$ of P-fertilized A. glabra in the present study (Figure 25) demonstrates that physiological processes affecting $\mathrm{C}$-isotope discrimination were affected by nutrient addition coupled with hydrology. The non-significant pattern in Nfertilized and Control trees suggests that variation in $\delta^{13} \mathrm{C}$ of P-fertilized A. glabra trees is likely the result of the added limited nutrient, P, stimulating photosynthesis. This is further corroborated by overall increase in $\delta^{13} \mathrm{C}$ in response to P-fertilization (Figure 20). Serret et al., (2008) hypothesized that the increase in $\delta^{13} \mathrm{C}$ of fertilized plants could be because of a decrease in the ratio of intercellular to ambient $\mathrm{CO}_{2}$ concentrations caused by a higher stomatal limitation of photosynthesis or more carboxylation capacity of 
photosynthetic tissues or both. Some short term in vitro studies have shown that $\mathrm{P}$ limitation can reduce the rate of photosynthesis in plants (see Rao and Terry, 1995). In the same study, they demonstrated that the rate of photosynthesis is controlled by ribulose 1,5-biphosphate (RuBP); low P reduced photosynthesis and RuBP levels, and resupply increased photosynthesis in sugar beets. Inglett and Reddy (2006) reported increasing pattern of $\delta^{13} \mathrm{C}$ and photosynthesis with $\mathrm{P}$ availability (towards inflows) for Typha species in Water conservation Area-2A, Florida. They argued that positive relationship between $\delta^{13} \mathrm{C}$ and higher photosynthesis limitation was a result of limitation on stomatal conductivity at high nutrient sites. Similarly, in the present study, trees with higher growth response by P-fertilization also exhibited higher $\delta^{13} \mathrm{C}$ (Figure 27). It could be possible that the higher photosynthesis (higher growth) rate corresponding with less

discrimination against ${ }^{13} \mathrm{C}$ due to the lack of significant changes in stomatal conductance along the RE. It is not surprising to see non-significant pattern observed in $\delta^{13} \mathrm{C}$ of $\mathrm{P}$ fertilized C. icaco trees (Figure 28) as neither growth nor $\delta^{13} \mathrm{C}$ were affected by nutrient treatments. However, direct photosynthetic measurements $\left(\mathrm{CO}_{2}\right.$ assimilation rate and stomatal conductance) of trees could readily define the hypothesis.

\subsection{Why are LILA tree islands P-limited?}

The nutrient analyses suggested that improved $\mathrm{P}$ supply was the principal reason for increased growth in LILA tree islands, which is in general agreement with the high P availability in Everglades tree islands. It is interesting to compare soil P in LILA to Everglades tree islands. The relatively low soil $\mathrm{P}$ content in LILA tree islands is uncharacteristic of Everglades tree islands. Soil TP for Control trees in this study were 
$0.013 \%$ and $0.014 \%$ under C. icaco and A. glabra trees respectively; while in Everglades tree island soils, soil TP concentrations of $3 \%$ in hammock, $0.1 \%$ on Bayhead and 0.07 in bayhead swamp have been reported (Jayachandran et al., 2004). Similarly, various authors (Orem et al. 2002, Ross et al., 2006, Gann Troxler et al, 2001, Wetzel 2009) reported extremely high phosphorous content at the head or center of islands compared with surrounding marsh. The discrepancies between LILA and Everglades tree islands in soil TP content is likely the result of tree island age. In Everglades tree islands, three major mechanisms have been hypothesized for the high $\mathrm{P}$ content in soil (Ross et al., 2006; Wetzel et al. 2005, Jayachandran et al., 2004)): 1) dissolved nutrients are carried toward the tree islands because of higher evapotranspiration, 2) contribution of animal (bird) inputs, and 3) the dynamics of organic matter. Being a very young ( $\sim 6$ years old) island with 3 year old trees, all three of these mechanisms are at a preliminary stage in LILA tree islands, and it could take a long time to accumulate nutrients to the same level as in Everglades tree islands. Ross and Sah (2010) argued that when tree islands are at early stages of development, tree growth can be limited by $\mathrm{P}$, but this might not be the same in mature forest ecosystems like hammock tree islands in Everglades. Also, as calcite can adsorb P (Zhou and Li, 2001) and render it unavailable for plant growth, the availability of phosphorus to species growing on limestone tree island soils could be P-limited. For example the earlier study by Troxler $e t$ al., (2005) found that southern Everglades tree islands were P limited, despite the presence of high $\mathrm{P}$ and $\mathrm{N}$ in soils. 


\section{CONCLUSIONS}

The present study showed that fertilization experiments proved successful in determining the growth-limiting nutrient in two tree islands species in the LILA tree islands. This experiment identified the difference between LILA and Everglades tree islands in plant nutrient availability. Leaf nutrient ratios (N:P) analysis seem particularly adaptable to evaluations of the availability of nutrients for the tree islands species. The present study is consistent with Koerselman and Meuleman (1996), at least in so far as the upper limit $(\mathrm{N}: \mathrm{P}>16)$ for P-limitation in tree islands, though the low critical ratio could not be tested due to lack of a combined $(\mathrm{N}+\mathrm{P})$ treatment. As a result, foliar $\mathrm{N}: \mathrm{P}$ ratios can be used to identify and predict how changing environment alters nutrient availability and the shift between $\mathrm{N}$ and $\mathrm{P}$ limitation. Leaf nutrient ratio may be a useful tool to assess whether and how humans impact the relative supplies of $\mathrm{N}$ and $\mathrm{P}$ and in monitoring and evaluation of conservation management efforts (Gusewell et al. 2000). It can be also used to examine how changes in the relative availability of $\mathrm{N}$ and $\mathrm{P}$ influence plant species composition or various ecological processes in tree islands (Bedford et al. 1999; Olde Venterink 2000). However, N:P ratios need to be calibrated properly with other physiological indicators like stomatal conductivity, net photosynthetic rate, etc. to provide a better idea of the nature of nutrient limitation.

The experiment identified a clear difference in species growth responses to substrate type, as limestone tree islands seem to be a more beneficial environment for the less flood tolerant species (C. icaco). It appears likely that species growth and survival depends not only on hydrology but also nutrient availability, particularly P. Therefore, the present 
study may be very helpful in the design of management systems for tree islands, especially at LILA, which are at early stages of development.

The results reported here were from 1-year study. Because plants sometimes are delayed in their response to nutrient addition; a longer term experiment needs to be completed before applying the conclusions in ecosystem and natural resource management in Everglades tree islands. In order to test the generality of the results, further experimentation should also include species that co-occur with A. glabra and C. icaco. 


\section{LITERATURE CITED}

Aerts R, F. S. Chapin III. 2000. The mineral nutrition of wild plants revisited: a reevaluation of processes and patterns. Adv Ecol Res 30:1-67.

Anderson, W.T, L.S.L. Sternberg, M.C. Pinzon, T. Gann-Troxler, D.L. Childers, M.Duever. 2005. Carbon isotopic composition of cypress trees from South Florida and changing hydrologic conditions. Dendrochronologia 23:1-10.

Armentano, T.V., Jones, D.T., Ross, M.S. and Gamble, B.W. 2002. Vegetation pattern and process in tree islands of the southern Everglades and adjacent areas. In: Sklar, F.H. Survival and growth responses of eight Everglades tree species 9 and van der Valk, A. (eds.) Tree islands of the Everglades. pp. 225-282. Kluwer Academic, Dordrecht, NL.

Austin, A. T. and P.M. Vitousek. 1998. Nutrient dynamics on a precipitation gradient in Hawai'i. Oecologia 113:519-529.

Bedford L.B., M R.Walbridge, and A. Aldous. 1999. Patterns in nutrient availability and plant diversity of temperate North American wetlands. Ecology 80(7): 2151-2169.

Best E.P.H, H. Woltman, and F. H. Jacobs. 1996. Sediment-related growth limitation of Elodea nuttallii as indicated by a fertilization experiment. Freshwater Biology 36(1): 33-44.

Burns, I.G. 1992. Influence of plant nutrient concentration on growth rate: Use of a nutrient interruption technique to determine critical concentrations of $\mathrm{N}, \mathrm{P}$ and $\mathrm{K}$ in young plants. Plant and Soil 142: 221-233.

Chapin III, F. S. 1980. The Mineral Nutrition of Wild Plants. Annual Review of Ecology and Systematics 11: 233-260.

Clarkson, B.R., L. A. Schipper, B. Moyersoen, and W. B. Silvester. 2005. Foliar 15N natural abundance indicates phosphorus limitation of bog species. Oecologia 144 (4): 550-557.

Conner, W.H. and J.W.Day Jr. 1991. Leaf litter decomposition in three Louisiana freshwater forested wetland areas with different flooding regimes. Wetlands 11(2): 303-312.

Cowan I.R. 1982. Regulation of water use in Relation to Carbon Gain in Higher Plants. In: Lange OL, Nobel PS, Osmond CB, Ziegler H (eds), Encyclopedia of Plant Physiology, Vol. 12B, Physiological Plant Ecology II, Water Relations and Carbon Assimilation. Springer-Verlag, Berlin-Heidelberg-New York, 589-613. 
Craine, J.M., C. M. and W. D. Stock. 2008. Nutrient concentration ratios and colimitation in South African grasslands. New Phytologist 179: 829-836.

Daoust, R. J. and D. L. Childers. 1999. Controls on emergent macrophytic composition, abundance, and productivity in freshwater Everglades wetland communities. Wetlands 19: 262-275.

Drenovsky, R.E. and J.H. Richards. 2004. Critical N:P values: Predicting nutrient deficiencies in desert shrublands. Plant and Soil 259: 59-69.

Evans, R. D. 2001. Physiological mechanisms influencing plant nitrogen isotope composition. Trends Plant Science 6: 121-126.

Farquhar, G. D., M. H. O’Leary, and J. A. Berry. 1982. On the relationship between carbon isotope discrimination and the intercellular carbon dioxide concentration in leaves. Journal of Plant Physiology 9:121-137.

Feller, I.C. 1995. Effects of Nutrient Enrichment on Growth and Herbivory of Dwarf Red Mangrove (Rhizophora Mangle). Ecological Monographs 65(4): 477-505.

Feller, I.C., D.F Whigham, J.P. O’Neill, and K. M. McKee. 1999. Effects of nutrient enrichment on within-stand nutrient cycling in mangrove ecosystems in Belize. Ecology 80: 2193-2205.

Feller, I.C., D.F.Whigham, K.M. McKee, and J.P. O’Neill. 2002. Nitrogen vs. phosphorus limitation across an ecotonal gradient in a mangrove forest. Biogeochemistry 62: 145- 175 .

Ferdie M, and J. W. Fourqurean. 2004. Responses of seagrass communities to fertilization along a gradient of relative availability of nitrogen and phosphorus in a carbonate environment. Limnology Oceanography 49:2082-2094.

Flipse, W. J. Jr., F. T. Bonner. 1985. Nitrogen-isotope ratios of nitrate in Ground Water under fertilized fields, Long Island, New York. Ground Water 23(1): 59-67.

Fourqurean, J. W. and J. C. Zieman. 1992. Phosphorus Limitation of Primary Production in Florida Bay: Evidence from C: N: P Ratios of the Dominant Seagrass Thalassia testudinum. Limnology and Oceanography 37(1): 162-171.

Fry, B., A. L. Bern, M. S. Ross, and J. F. Meeder. 2000. $\delta^{15} \mathrm{~N}$ studies of nitrogen use by the red mangrove, Rhizophora mangle L., in South Florida. Estuarine, Coastal and Shelf Science 50:723-735.

Gautam, S. and M. Z. Iqbal, 2010. Using stable isotopes of nitrogen to study its source and transformation in a heavily farmed watershed. Environ Earth Sci 60:11-20. 
Gonzáleza, Eduardo, Etienne Mullerb,c, Francisco Antonio Comína, María GonzálezSanchisa, 2010. Leaf nutrient concentration as an indicator of Populus and Tamarix response to flooding Perspectives in Plant Ecology, Evolution and Systematics 12: 257-266.

Grime, J. P. 1998. Benefits of plant diversity to ecosystems: immediate, filter, and founder effects. Journal of Ecology 86: 902-910.

Grime, J.P. 1977. Evidence for the existence of three primary strategies in plants and its relevance to ecological and evolutionary theory. The American Naturalists 111(982):1169-1194.

Gunderson, L.H., J.R. Stenberg, and A.K. Herndon. 1988. Tolerance of five hardwood species to flooding regimes. In: Wilcox, D.A. (ed.) Interdisciplinary approaches to freshwater wetlands research. pp. 119-132. Michigan State University Press, East Lansing, MI, US.

Güsewell S., W. Koerselman, and J. T. A. Verhoeven. 2003. Biomass N:P Ratios as Indicators of Nutrient Limitation for Plant Populations in Wetlands. Ecological Applications 13(2): 372-38.

Güsewell, S and W. Koerselman. 2002. Variation in nitrogen and phosphorus concentrations of wetland plants. Perspective plant ecology, evolution and systematic 5(1): 37-61.

Güsewell, S. 2004. N:P ratios in terrestrial plants: variation functional significance. New Phytol. 164:243-66.

Hanan E. J. and M S. Ross. 2010. Across-scale patterning of plant-soil-water interactions surrounding tree islands in Southern Everglades landscapes. Landscape Ecology 25(3): 463-476.

Hinsinger, P. 2001. Bioavailability of soil inorganic P in the rhizosphere as affected by root-induced chemical changes: a review. Plant Soil 237:173-195.

Hubner, H. 1986. Isotope effects of nitrogen in the soil and biosphere. In Fritz P, Fontes JC (eds) Handbook of environmental isotope geochemistry, the terrestrial environment, vol 2b. Elsevier Science, Amsterdam, pp 361-425.

Inglett P. W., K. R. Reddy, S. Newman and B. Lorenzen. 2007. Increased soil stable nitrogen isotopic ratio following phosphorus enrichment: historical patterns and tests of two hypotheses in a phosphorus-limited wetland. Oecologia 153:99-109. 
Inglett, P. W. and K. R. Reddy. 2006. Investigating the use of macrophyte stable C and N isotopic ratios as indicators of wetland eutrophication: Patterns in the P-affected Everglades. Limnology Oceanography 51:2380-2387.

Inglett, P. W., K. R. Reddy, and P. V. McCormick. 2004. Periphyton chemistry and nitrogenase activity in a northern Everglades ecosystem. Biogeochemistry $67: 213-233$.

Jayachandran, K., S. K. Sah, J. P. Sah, and M. S. Ross. 2004. Characterization, Biogeochemistry, Pore Water Nutrient Chemistry, and Other Aspects of Soils in Tree Islands of Shark Slough. In Tree Islands in the Shark Slough Landscape: interactions of Vegetation, Hydrology and Soils, ed. M. S. Ross and D. T. Jones, 45-82. Report submitted to Everglades National Park.

Jones, D.T., J.P. Sah, M.S. Ross, S.F. Oberbauer, B. Hwang, and K. Jayachandran. 2006. Responses of twelve tree species common in Everglades tree islands to simulated hydrologic regimes. Wetlands 26: 830-844.

Jones, R. I., King L., Dent M. M., Maberly S. C., and Gibson C. E., 2004. Nitrogen stable isotope ratios in surface sediments, epilithon and macrophytes from upland lakes with differing nutrient status. Freshwater Biology 49: 382-391.

Koch, M. S. and K. R. Reddy, 1992. Distribution of soil and plant nutrients along a tropic gradient in the Florida Everglades. Soil Sci. Soc. Am. J. 56:1492-1499.

Koerselman, W. and A. F. M. Meuleman. 1996. The Vegetation N:P Ratio: a New Tool to Detect the Nature of Nutrient . Journal of Applied Ecology 33(6): 1441-1450.

Lin, G., and L. S. L. Sternberg. 1992. Effect of growth form, salinity, nutrient and sulfide on photosynthesis, carbon isotope discrimination and growth of red mangrove (Rhizophora mangle L.). Australian Journal of Plant Physiology 19:509-517.

Lin, G., and L. S. L. Sternberg. 2007. Nitrogen and Phosphorous dynamics and nutrient resorption of Rhizophora mangle leaves in South Florida, USA. Bulletin of Marine Science 80(1): 159-169.

Lockaby, B.G. and W. H. Conner. 1999. N:P Balance in Wetland Forests: Productivity across a Biogeochemical Continuum. The Botanical Review 65(2): 171-185.

Lovelock, C. E., I. C. Feller, K. L. Mckee, B. M. J. Engelbrecht, and M. C. Ball. 2004. The effect of nutrient enrichment on growth, photosynthesis and hydraulic conductance of dwarf mangroves in Panamá. Functional Ecology, 18(1) 25-33. 
McKee KL, I. C. Feller, M. Popp, and W. Wanek. 2002. Mangrove isotopic $\left(\delta^{15} \mathrm{~N}\right.$ and $\delta^{13} \mathrm{C}$ ) fractionation across a nitrogen vs. phosphorus limitation gradient. Ecology 83:1065-1075.

Mitsch, W.J. and J.G. Gosselink. 2007. Wetlands. 4th edn. John Wiley and Sons Inc., New Jersey, USA.

Montoya, J. P., and J. J. McCarthy. 1995. Isotopic fractionation during nitrate uptake by phytoplankton grown in continuous culture. Journal of Plankton Research 17:439-464.

Neatrour, M A., R. H. Jones, and S.W. Golladay. 2008. Assessment of Nutrient Limitation in Floodplain Forests with Two Different Techniques. Research Letters in Ecology: 1-4.

Noe, G. B., D L. Childers, and J. D. Ronald 2001. Phosphorus biogeochemistry and the impact of phosphorus enrichment: Why is the Everglades so unique? Ecosystems 4: 603-624.

Novak, M., F. Buzeka, and M. Adamova. 1999. Vertical trends in $\delta^{13} \mathrm{C}, \delta^{15} \mathrm{~N}$ and $\delta^{34} \mathrm{~S}$ ratios in bulk Sphagnum peat. Soil Biol. Biochem. 31: 1343-1346.

Oheimb, G., S. A. Power, K. Falk, U. Friedrich, A. Mohamed, A. Krug, N. Boschatzke, and W. Hardtle. 2010. N:P Ratio and the Nature of Nutrient Limitation in Calluna-Dominated Heathlands. Ecosystems 13: 317-327.

Olde Venterink, H., R. E. Van der Vliet, and M. J. Wassen. 2001. Nutrient limitation along a productivity gradient in wet meadows. Plant Soil 234: 171-179.

Olde Venterink, H., T.E. Davidsson, K. Kiehl, and L. Leonardson. 2002. Impact of drying and re-wetting on N, P and K dynamics in a wetland soil. Plant and Soil 243: 119-130.

Orem, W. H., D. A. Willard, H. E. Lerch, A. L. Bates, A. Boylan, and M. Corum. 2002. Nutrient geochemistry of sediments from two tree islands in Water Conservation Area 3B, the Everglades, Florida. Pages 153-186 in F. H. Sklar and A. van der Valk, editors. Tree islands of the Everglades. Kluwer Academic, Dordrecht, The Netherlands.

Perez, M., j. Romero, C.M. Duarte, and K. Sand-Jensen. 1991. Phosphorus limitation of Cymodocea nodosa growth. Marine Biology 109, 129 -133.

Pons, T.L, J. Flexas, S. von Caemmerer, J.R. Evans, B. Genty, M. Ribas-Carbo, E. Brugnoli. 1994. Estimating mesophyll conductance to CO2: methodology, 
potential errors, and 20 recommendations. Journal of Experimental Botany 60: 2217-2234.

Rao, M and N. Terry. 1995. Leaf phosphate status, photosynthesis, and carbon partitioning in sugar beat. Plant physiology 107: 1313-1321.

Raven, J.A. 1992. Present and Potential uses of the natural abundance of stable isotopes in plant science, with illustrations from the marine environment. Plant Cell and Environment 15(9): 1083-1091.

Richardson CJ, Ferrell GM, Vaithiyanathan P. 1999. Nutrient effects on stand structure, resorption efficiency and secondary compounds in everglades sawgrass. Ecology 80(7): 2182-2192.

Ricklefs and Miller 1999. Ecology. Fourth Ed. W.H. Freeman and Co. New York.

Ross, M. S., S. Mitchell-Bruker, J. P. Sah, S. Stothoff, P. L. Ruiz, D. L. Reed, K. Jayachandran, and C. L. Coultas. 2006. Interaction of hydrology and nutrient limitation in the Ridge and Slough landscape of the southern Everglades. Hydrobiologia (2006) 569:37-59.

Ross, M.S, and J.P. Sah. 2010. Forest resource islands in a sub-tropical marsh: soil:site relationships in Everglades hardwood hammocks: Shortened version: Soil: site relationships in Everglades tree islands. Ecosystems.

Ross, M.S. D.L. Reed, J.P. Sah, P.L. Ruiz and M.T. Lewin. 2003. Vegetation: environment relationships and water management in Shark Slough, Everglades National Park. Wetlands Ecology and Management 11: 291-303.

Saha, A. K., L. S. L.Sternberg, and F. Miralles-Wilhelm. 2009. Linking water sources with foliar nutrient status in upland plant communities in the Everglades National Park, USA. Ecohydrology 2: 42-54.

Schulze, F.S., F. S. Chapin III, and G. Gebauer. 1994. Nitrogen nutrition and isotope differences among life forms at the northern treeline of Alaska, Oecologia 100: 406-412.

Serret, M.D., I. Ortiz-Monasterio, A. Pardo, and J.L. Araus. 2008. The effects of urea fertilization and genotype on yield, nitrogen use efficiency, d15N and d $13 \mathrm{C}$ in wheat. Annals of Applied Biology 243-257.

Shaver G. R. and F. S. Chapin III. 1980. Response to Fertilization by various plant growth forms in an Alaskan Tundra: Nutrient accumulation and growth. Ecology 61(3): 662-675. 
Shure D. J, M. R. Gottschalk, and K. A. Parsons, 1981. Decomposition and nutrient release from litter in a South Carolina floodplain forest. Ecological Society of America Bulletin 62:112.

Sklar, F.H. and A.van der Valk. 2002. Tree islands of the Everglades: an overview. In: Sklar, F.H. and van der Valk, A. (eds.) Tree islands of the Everglades. Kluwer Academic, Dordrecht, NL.

Soudzilovskaia, N.A., V.G. Onipchenko, J.H.C. Cornelissen, and R. Aerts. 2005. Biomass production, $\mathrm{N}: \mathrm{P}$ ratio and nutrient limitation in a Caucasian alpine tundra plant community. Journal of Vegetation Science 16: 399-406.

Sterner, R. W. and J. J. Elser. 2002. Ecological Stoichiometry, the biology of elements from molecules to the biospheres. Princeton University Press.

Stoffella, S L., M.S. Ross, J.P. Sah, R. M. Price, P. L. Sullivan, E. A. Cline, and L. J. Scinto. 2010. Survival and growth responses of eight Everglades tree species along an experimental hydrological gradient on two tree island types. Applied Vegetation Science: 1-11.

Sullivan, P. L., R. M. Price, M. S. Ross, L. J. Scinto, S. L. Stoffella, E. Cline, T. W. Dreschel and F. H. Sklar. 2010. Hydrologic processes on tree islands in the Everglades (Florida, USA): tracking the effects of tree establishment and growth. Hydrogeology journal (online).

Tessier, J. T. and D. J. Raynal. 2003. Use of nitrogen to phosphorus ratios in plant tissue as an indicator of nutrient limitation and nitrogen saturation. Journal of Applied Ecology 40: 523-534.

Tomlinson, P.B. 1980. The biology of trees native to tropical Florida. Harvard University Printing Office, Allston, MA, US.

Troxler T. G., D. L. Childers, and D. N. Rondeau. 2005. Ecosystem structure, nutrient dynamics, and hydrologic relationships in tree islands of the southern Everglades, Florida, USA. Forest Ecology and Management 214. 11-27.

van der Valk, A.G., P. Wetzel, E. Cline, and F.H. Sklar. 2007. Restoring tree islands in the Everglades: experimental studies of tree seedling survival and growth. Restoration Ecology 16: 281-289.

van der Woude, B. J., D. M. Pegtel, and J. P. Bakker. 1994. Nutrient limitation after longterm nitrogen fertilizer application in cut grasslands. Journal of Applied Ecology 31: 405-412. 
van Duren, I. C. and D. M. Pegtel. 2000. Nutrient limitations in wet, drained and rewetted fen meadows: evaluation of methods and results. Plant and Soil 220:35-47.

Verhoeven J.T.A., W. Koerselman and A.F.M. Meuleman. 1996. Nitrogen- or phosphorus-limitegdr owth in herbaceous wet vegetation: relations with atmospheric inputs and management regimes. Trends in ecology and evolution 11(12): 494-497.

Vitousek, P. M., and R. W. Howarth. 1991. Nitrogen limitation on land and in the sea: how can it occur? Biogeochemistry 13:87-115.

Vitousek, P. M., D. R. Turner, and K. Kitayama. 1995. Foliar nutrients during long-term soil development in Hawaiian montane rain forest. Ecology 76: 712-720.

Vitousek, P. M., L. R. Walker, L. D. Whiteaker, and P. A. Matson. 1993. Nutrient limitation to plant growth during primary succession in Hawaii Volcanoes National Park. Biogeochem. 23: 197-215.

Wang, X., L.O. Sternberg, M. S. Ross, and V. C. Engel. 2010. Linking water use and nutrient accumulation in tree island upland hammock plant communities in the Everglades National Park, USA. Biogeochemistry (online).

Wetzel P R., A. G. van der Valk, S. Newman, C. A. Coronado, T. G. Troxler-Gann, D. L. Childers, W. H. Orem, and F. H. Sklar. 2009. Heterogeneity of phosphorus distribution in a patterned landscape, the Florida Everglades. Plant Ecology 200:83-90.

Wetzel, P R., T. Pinion, D. T. Towles, and L. Heisler. 2008. Landscape analysis of tree island head vegetation in water conservation area 3, Florida Everglades. Wetlands 28(2): 276-289.

Wetzel, P.R., van der Valk, A.G., Newman, S., Gawlik, D.E., Gann, T., CoronadoMolina, C.A., Childers, D.L. and Sklar, F.H. 2005. Maintaining tree islands in the Florida Everglades: nutrient redistribution is the key. Frontiers in Ecology and Environment 3: 370-376.

Wooller, M., B. Smallwood, M. Jacobson, and M. Fogel. 2003. Carbon and nitrogen stable isotopic variation in Laguncularia racemosa (L.) (white mangrove) from Florida and Belize: Implications for trophic level studies. Hydrobiologia 499:1323.

Zhou, M. and Y. Li. 2001. Phosphorus-sorption characteristics of calcareous soils and limestone from the southern Everglades and adjacent farmlands. Soil Science Society of America Journal 65: 1404-1412. 


\section{APPENDIX I}

Two-way ANOVA results for A. glabra and C. icaco responses to nutrient treatments and substratum. Response variable: Growth $=\Delta$ height $(\mathrm{cm})$; total nitrogen in leaf $=\mathrm{TN}$, total phosphorous in leaf $=\mathrm{TP}$, Leaf nitrogen and Phosphorous ratio $=\mathrm{N}: \mathrm{P}$, leaf $\delta^{15} \mathrm{~N}$, and leaf $\delta^{13} \mathrm{C}$; Treatment effect: island type: limestone or peat $=$ Substratum $(\mathrm{Sub})$; Nutrient $=$ Nut (N, P and Control) . (*) indicating significant effect (P-value $<0.05)$.

\begin{tabular}{|c|c|c|c|c|c|}
\hline Species & Response & Effect & DF & $\mathbf{F}$ & p-value \\
\hline \multirow{18}{*}{ A. glabra } & \multirow{3}{*}{ Growth } & Nut & 2 & 6.613 & $0.01 *$ \\
\hline & & Sub & 1 & 0.007 & 0.93 \\
\hline & & Nut*Sub & 2 & 0.879 & 0.42 \\
\hline & \multirow{3}{*}{ Leaf TN } & Nut & 2 & 2.755 & 0.07 \\
\hline & & Sub & 1 & 4.873 & $0.03 *$ \\
\hline & & Nut*Sub & 2 & 0.312 & 0.73 \\
\hline & \multirow{3}{*}{ Leaf TP } & Nut & 2 & 38.960 & $0.01 *$ \\
\hline & & Sub & 1 & 1.400 & 0.24 \\
\hline & & Nut*Sub & 2 & 2.700 & 0.07 \\
\hline & \multirow{3}{*}{ Leaf N:P } & Nut & 2 & 58.28 & $0.01 *$ \\
\hline & & Sub & 1 & 1.990 & 0.16 \\
\hline & & Nut*Sub & 2 & 2.450 & 0.09 \\
\hline & \multirow[t]{3}{*}{ Leaf $\delta^{13} \mathrm{C}$} & Nut & 2 & 6.155 & $0.01 *$ \\
\hline & & Sub & 1 & 0.001 & 0.97 \\
\hline & & Nut*Sub & 2 & 1.297 & 0.28 \\
\hline & \multirow{3}{*}{ Leaf $\delta^{15} \mathrm{~N}$} & Nut & 2 & 6.284 & $0.02 *$ \\
\hline & & Sub & 1 & 0.208 & 0.65 \\
\hline & & Nut*Sub & 2 & 0.633 & 0.53 \\
\hline \multirow{18}{*}{ C. icaco } & \multirow{3}{*}{ Growth } & Nut & 2 & 0.005 & 0.99 \\
\hline & & Sub & 1 & 9.693 & $0.01 *$ \\
\hline & & Nut*Sub & 2 & 0.019 & 0.98 \\
\hline & \multirow{3}{*}{ Leaf TN } & Nut & 2 & 0.007 & 0.99 \\
\hline & & Sub & 1 & 6.766 & $0.01 *$ \\
\hline & & Nut*Sub & 2 & 0.895 & 0.41 \\
\hline & \multirow{3}{*}{ Leaf TP } & Nut & 2 & 19.900 & $0.01 *$ \\
\hline & & Sub & 1 & 3.260 & 0.07 \\
\hline & & Nut*Sub & 2 & 5.490 & $0.01 *$ \\
\hline & \multirow{3}{*}{ Leaf N:P } & Nut & 2 & 24.270 & $0.01 *$ \\
\hline & & Sub & 1 & 1.960 & 0.16 \\
\hline & & Nut*Sub & 2 & 3.410 & $0.04 *$ \\
\hline & \multirow{3}{*}{ Leaf $\delta^{13} \mathrm{C}$} & Nut & 2 & 0.654 & 0.52 \\
\hline & & Sub & 1 & 2.149 & 0.14 \\
\hline & & Nut*Sub & 2 & 0.118 & 0.88 \\
\hline & \multirow{3}{*}{ Leaf $\delta^{15} \mathrm{~N}$} & Nut & 2 & 3.765 & $0.03 *$ \\
\hline & & Sub & 1 & 0.304 & 0.58 \\
\hline & & Nut*Sub & 2 & 2.433 & 0.09 \\
\hline
\end{tabular}




\section{APPENDIX II}

Two-way ANOVA results for soil nutrient content of $A$. glabra and $C$. icaco trees with respect to nutrient treatments and substratum. Response variable: total nitrogen in soil = Soil TN, total phosphorous in soil= Soil TP, Soil nitrogen and Phosphorous ratio = Soil N:P. Treatment effect: Substratum type: limestone or peat $=\mathrm{Sub}$; Nutrient $=$ Nut $(\mathrm{N}, \mathrm{P}$ and Control)

\begin{tabular}{|c|c|c|c|c|c|}
\hline Species & Response & Effect & DF & $\mathbf{F}$ & p-value \\
\hline \multirow{9}{*}{ A. glabra } & \multirow{3}{*}{ Soil TN } & Nut & 2 & 0.06 & 0.94 \\
\hline & & Sub & 1 & 2.54 & 0.12 \\
\hline & & Nut*Sub & 2 & 0.04 & 0.95 \\
\hline & \multirow{3}{*}{ Soil TP } & Nut & 2 & 3.10 & 0.06 \\
\hline & & Sub & 1 & 5.90 & $0.02 *$ \\
\hline & & Nut*Sub & 2 & 1.87 & 0.17 \\
\hline & \multirow{3}{*}{ Soil N:P } & Nut & 2 & 0.69 & 0.51 \\
\hline & & Sub & 1 & 0.04 & 0.83 \\
\hline & & Nut*Sub & 2 & 3.28 & 0.06 \\
\hline \multirow{9}{*}{ C. icaco } & \multirow{3}{*}{ Soil TN } & Nut & 2 & 2.13 & 0.14 \\
\hline & & Sub & 1 & 0.27 & 0.60 \\
\hline & & Nut*Sub & 2 & 0.41 & 0.66 \\
\hline & \multirow{3}{*}{ Soil TP } & Nut & 2 & 4.00 & $0.03 *$ \\
\hline & & Sub & 1 & 0.24 & 0.58 \\
\hline & & Nut*Sub & 2 & 0.69 & 0.50 \\
\hline & \multirow{3}{*}{ Soil N:P } & Nut & 2 & 3.84 & $0.03 *$ \\
\hline & & Sub & 1 & 0.06 & 0.79 \\
\hline & & Nut*Sub & 2 & 0.10 & 0.90 \\
\hline
\end{tabular}

Note: $\left(^{*}\right)$ indicating significant effect $(\mathrm{P}$-value $<0.05)$. 


\section{APPENDIX III}

Results of the literature search on $\mathrm{N}: \mathrm{P}$ ratios and nutrient limitation in vegetation. The columns ' $\mathrm{N}$ limitation' and 'P limitation' indicate the $\mathrm{N}: \mathrm{P}$ ratio at which the authors of the cited studies suggest that their respective ecosystem is limited by the indicated nutrient

\begin{tabular}{|c|c|c|c|c|c|c|c|}
\hline Study & System & Location & Additions & $N: P$ & Limited & $\begin{array}{l}\text { Limitation } \\
\text { By } N\end{array}$ & $\begin{array}{l}\text { Limitation } \\
\text { by } P\end{array}$ \\
\hline \multicolumn{8}{|l|}{ Estuaries } \\
\hline $\begin{array}{l}\text { Doering et al. } \\
\text { (1995) }\end{array}$ & Estuary & Laboratory & $\mathrm{N}$ and $\mathrm{P}$ & $15 \cdot 6$ & $\mathrm{~N}$ & & \\
\hline $\begin{array}{l}\text { Murray, } \\
\text { Dennison and } \\
\text { Kemn }(1992)\end{array}$ & Estuary & Virginia & $\mathrm{N}$ and $\mathrm{P}$ & $14-18$ & $\mathrm{~N}$ and $\mathrm{P}$ & & \\
\hline $\begin{array}{l}\text { Doering et al. } \\
\text { (1995) }\end{array}$ & Estuary & Laboratory & $\mathrm{N}$ and $\mathrm{P}$ & $20 \cdot 4$ & $\mathrm{P}$ & & \\
\hline $\begin{array}{l}\text { Doering et al. } \\
\text { (1995) }\end{array}$ & Estuary & Laboratory & $\mathrm{N}$ and $\mathrm{P}$ & $25 \cdot 9$ & $\mathrm{P}$ & & \\
\hline $\begin{array}{l}\text { Doering et al. } \\
\text { (1995) }\end{array}$ & Estuary & Laboratory & $\mathrm{N}$ and $\mathrm{P}$ & $28 \cdot 9$ & $\mathrm{P}$ & & \\
\hline \multicolumn{8}{|l|}{ Shores } \\
\hline $\begin{array}{l}\text { Koerselman } \\
\text { (1992) }\end{array}$ & $\begin{array}{l}\text { Coastal } \\
\text { dunes }\end{array}$ & $\begin{array}{l}\text { The } \\
\text { Netherlands }\end{array}$ & & & & $<16$ & $>25$ \\
\hline \multicolumn{8}{|l|}{ Wetlands } \\
\hline $\begin{array}{l}\text { Vermeer } \\
(1986 a)\end{array}$ & $\begin{array}{l}\text { Wet } \\
\text { grassland }\end{array}$ & $\begin{array}{l}\text { The } \\
\text { Netherlands }\end{array}$ & $\mathrm{N}$ and $\mathrm{P}$ & $5 \cdot 4$ & $\mathrm{~N}$ & & \\
\hline $\begin{array}{lr}\text { Aerts, } & \text { Wallén } \\
\text { and } & \text { Malmer } \\
(1992) & \end{array}$ & $\begin{array}{l}\text { Sphagnu } \\
\text { m bog }\end{array}$ & Sweden & $\mathrm{N}$ and $\mathrm{P}$ & 6 & $\mathrm{~N}$ & & \\
\hline $\begin{array}{l}\text { Boeye et al. } \\
\text { (1997) }\end{array}$ & $\begin{array}{l}\text { Wet } \\
\text { meadow }\end{array}$ & Belgium & $\mathrm{N}$ and $\mathrm{P}$ & $\begin{array}{l}7 \cdot 6- \\
9 \cdot 0\end{array}$ & $\mathrm{~N}$ & & \\
\hline $\begin{array}{l}\text { Verhoeven and } \\
\text { Schmitz (1991) }\end{array}$ & Fen & $\begin{array}{l}\text { The } \\
\text { Netherlands }\end{array}$ & $\mathrm{N}$ and $\mathrm{P}$ & 11.95 & $\mathrm{~N}$ & & \\
\hline $\begin{array}{l}\text { Boeye et al. } \\
(1997)\end{array}$ & Fen & Belgium & $\mathrm{N}$ and $\mathrm{P}$ & $\begin{array}{l}13 \cdot 1- \\
14 \cdot 7\end{array}$ & $\mathrm{~N}$ & & \\
\hline $\begin{array}{l}\text { Vermeer } \\
\text { (1986b) }\end{array}$ & Fen & $\begin{array}{l}\text { The } \\
\text { Netherlands }\end{array}$ & $\mathrm{N}$ and $\mathrm{P}$ & $13 \cdot 3$ & $\mathrm{~N}$ & & \\
\hline $\begin{array}{l}\text { Boyer and } \\
\text { Wheeler (1989) }\end{array}$ & Fen & England & $\mathrm{P}$ & $14 \cdot 6$ & $\mathrm{P}$ & & \\
\hline Loach (1968) & Bog & England & $\mathrm{N}$ and $\mathrm{P}$ & $21 \cdot 4$ & $\mathrm{P}$ & & \\
\hline $\begin{array}{l}\text { Boyer and } \\
\text { Wheeler (1989) }\end{array}$ & Fen & England & $P$ & $22 \cdot 0$ & $P$ & & \\
\hline Tamm (1954) & Bog & Sweden & $N$ and $P$ & $23 \cdot 0$ & $N$ & & \\
\hline $\begin{array}{l}\text { Boeye et al. } \\
\text { (1997) }\end{array}$ & Fen & Belgium & $\mathrm{N}$ and $\mathrm{P}$ & $\begin{array}{l}23 \cdot 3- \\
30 \cdot 7\end{array}$ & $P$ & & \\
\hline $\begin{array}{l}\text { Verhoeven and } \\
\text { Schmitz (1991) }\end{array}$ & Fen & $\begin{array}{l}\text { The } \\
\text { Netherlands }\end{array}$ & $\mathrm{N}$ and $\mathrm{P}$ & $23 \cdot 85$ & $\mathrm{P}$ & & \\
\hline Loach (1968) & Bog & England & $\mathrm{N}$ and $\mathrm{P}$ & $25 \cdot 3$ & $\mathrm{P}$ & & \\
\hline Loach (1968) & Bog & England & $\mathrm{N}$ and $\mathrm{P}$ & $30 \cdot 0$ & $\mathrm{P}$ & & \\
\hline $\begin{array}{l}\text { Aerts, Wallén } \\
\text { and } \\
\text { Malmer }\end{array}$ & $\begin{array}{l}\text { Sphagnu } \\
\text { m bog }\end{array}$ & Sweden & $\mathrm{N}$ and $\mathrm{P}$ & 34 & $\mathrm{P}$ & $<10$ & $>14$ \\
\hline
\end{tabular}




\begin{tabular}{|c|c|c|c|c|c|c|c|}
\hline $\begin{array}{l}(1992) \\
\text { Boyer and } \\
\text { Wheeler (1989) }\end{array}$ & Fen & England & $\mathrm{P}$ & $54 \cdot 0$ & $\mathrm{P}$ & & \\
\hline $\begin{array}{l}\text { Wassen, Olde } \\
\text { Venterink and } \\
\text { de Swart (1995) }\end{array}$ & Mire & Poland & & & & $<14 \cdot 3$ & $>25$ \\
\hline $\begin{array}{l}\text { Verhoeven, } \\
\text { Koerselman and } \\
\text { Meuleman } \\
\text { (1996) }\end{array}$ & Wetland & $\begin{array}{l}\text { review } \\
\text { Europe }\end{array}$ & & & & $<14$ & $>16$ \\
\hline Penning de & Grasslan & Western & $\mathrm{N}$ and $\mathrm{P}$ & & & $<6.67$ & $>26 \cdot 32$ \\
\hline $\begin{array}{lr}\text { Vries, Krul and } \\
\text { van } & \text { Keulen } \\
(1980) & \end{array}$ & d & Africa & & & & & \\
\hline $\begin{array}{l}\text { von Oheimb et } \\
\text { al., (2010) }\end{array}$ & $\begin{array}{l}\text { Heathlan } \\
\text { ds }\end{array}$ & Germany & & & & & \\
\hline $\begin{array}{l}\text { Gusewell } \\
(2003)\end{array}$ & $\begin{array}{l}\text { Fens and } \\
\text { dunes }\end{array}$ & $\begin{array}{l}\text { The } \\
\text { Netherlands }\end{array}$ & $\mathrm{N}$ and $\mathrm{P}$ & & & & $>20$ \\
\hline $\begin{array}{l}\text { UPLANDS } \\
\text { de Visser et al. } \\
\text { (1994) }\end{array}$ & $\begin{array}{l}\text { Conifero } \\
\text { us forest }\end{array}$ & Europe & $\mathrm{N}$ & $\begin{array}{l}7 \cdot 0- \\
14 \cdot 5\end{array}$ & Not N & & \\
\hline $\begin{array}{lr}\text { Alan, } & \text { Taylor } \\
\text { and } & \text { Dicks } \\
(2000) & \end{array}$ & $\begin{array}{l}\text { Carica } \\
\text { papaya }\end{array}$ & Laboratory & $\mathrm{N}$ and $\mathrm{P}$ & 7 & $\mathrm{~N}$ and $\mathrm{P}$ & & \\
\hline $\begin{array}{l}\text { Jacobson and } \\
\text { Pettersson } \\
\text { (2001) }\end{array}$ & $\begin{array}{l}\text { Picea } \\
\text { abies } \\
\text { stand }\end{array}$ & Sweden & $\mathrm{N}$ and $\mathrm{P}$ & $7 \cdot 54$ & $\mathrm{~N}$ & & \\
\hline $\begin{array}{l}\text { Mohren, van } \\
\text { den Burg and } \\
\text { Burger (1986) }\end{array}$ & $\begin{array}{l}\text { Douglas } \\
\text { fir forest }\end{array}$ & $\begin{array}{l}\text { The } \\
\text { Netherlands }\end{array}$ & $\mathrm{N}$ and $\mathrm{P}$ & 8 & $\mathrm{~N}$ & & \\
\hline $\begin{array}{l}\text { Jacobson and } \\
\text { Pettersson } \\
(2001)\end{array}$ & $\begin{array}{l}\text { Pinus } \\
\text { sylvestris } \\
\text { stand }\end{array}$ & Sweden & $\mathrm{N}$ and $\mathrm{P}$ & $8 \cdot 96$ & $\mathrm{~N}$ & & \\
\hline $\begin{array}{l}\text { Clarholm and } \\
\text { Rosengren- } \\
\text { Brinck (1995) }\end{array}$ & $\begin{array}{l}\text { Picea } \\
\text { abies } \\
\text { plantatio } \\
\text { n }\end{array}$ & Sweden & $\mathrm{N}$ and $\mathrm{P}$ & $9 \cdot 8$ & $\mathrm{~N}$ and $\mathrm{P}$ & & \\
\hline Valentine and & & North & $\mathrm{N}$ and $\mathrm{P}$ & $10 \cdot 42$ & $\mathrm{~N}$ and $\mathrm{P}$ & & \\
\hline Allen (1990) & $\begin{array}{l}\text { Loblolly } \\
\text { pine } \\
\text { plantatio } \\
\text { n }\end{array}$ & Carolina & & & & & \\
\hline Bowman (1994) & $\begin{array}{l}\text { Alpine } \\
\text { dry } \\
\text { meadow }\end{array}$ & Colorado & $\mathrm{N}$ and $\mathrm{P}$ & 13 & $\mathrm{~N}$ & & \\
\hline $\begin{array}{l}\text { Herbert and } \\
\text { Fownes (1995) }\end{array}$ & $\begin{array}{l}\text { Montane } \\
\text { forest }\end{array}$ & Hawaii & $\mathrm{N}$ and $\mathrm{P}$ & $13 \cdot 83$ & $P$ & & \\
\hline Bowman (1994) & $\begin{array}{l}\text { Alpine } \\
\text { wet } \\
\text { meadow }\end{array}$ & Colorado & $\mathrm{N}$ and $\mathrm{P}$ & 14 & $\mathrm{P}$ & & \\
\hline
\end{tabular}




\begin{tabular}{|c|c|c|c|c|c|c|c|}
\hline $\begin{array}{l}\text { Ljungstrom and } \\
\text { Nihlgård (1995) }\end{array}$ & $\begin{array}{l}\text { Beech } \\
\text { forest }\end{array}$ & Europe & $\mathrm{P}$ & $14 \cdot 17$ & $\begin{array}{l}\text { At least } \\
\mathrm{P}\end{array}$ & & \\
\hline Bobbink (1991) & $\begin{array}{l}\text { Chalk } \\
\text { grassland }\end{array}$ & $\begin{array}{l}\text { The } \\
\text { Netherlands }\end{array}$ & $\mathrm{N}$ and $\mathrm{P}$ & $16 \cdot 08$ & $\mathrm{~N}$ and $\mathrm{P}$ & & \\
\hline $\begin{array}{l}\text { Tessier and } \\
\text { Raynal (2003) }\end{array}$ & $\begin{array}{l}\text { Forest } \\
\text { understor } \\
\text { ey }\end{array}$ & New York & $\mathrm{N}$ and $\mathrm{P}$ & $17 \cdot 71$ & $\mathrm{P}$ & & \\
\hline $\begin{array}{l}\text { Mohren, van } \\
\text { den Burg and } \\
\text { Burger (1986) }\end{array}$ & $\begin{array}{l}\text { Douglas } \\
\text { fir forest }\end{array}$ & $\begin{array}{l}\text { The } \\
\text { Netherlands }\end{array}$ & $\mathrm{N}$ and $\mathrm{P}$ & $22-25$ & $\mathrm{P}$ & & \\
\hline $\begin{array}{l}\text { Aerts and } \\
\text { Berendse (1988) }\end{array}$ & Heath & $\begin{array}{l}\text { The } \\
\text { Netherlands }\end{array}$ & $\mathrm{N}$ and $\mathrm{P}$ & $29 \cdot 41$ & $\mathrm{P}$ & & \\
\hline $\begin{array}{l}\text { Aerts and } \\
\text { Berendse (1988) }\end{array}$ & Heath & $\begin{array}{l}\text { The } \\
\text { Netherlands }\end{array}$ & $\mathrm{N}$ and $\mathrm{P}$ & $27 \cdot 5$ & $\mathrm{P}$ & & \\
\hline $\begin{array}{l}\text { Wall, Hellsten } \\
\text { and } \quad \text { Huss- } \\
\text { Danell }(2000)\end{array}$ & $\begin{array}{l}\text { Alnus } \\
\text { and } \\
\text { Trifoliu } \\
\text { m }\end{array}$ & Laboratory & $\mathrm{N}$ and $\mathrm{P}$ & & & $>7$ & \\
\hline $\begin{array}{l}\text { Ericsson et al. } \\
\text { (1993) }\end{array}$ & $\begin{array}{l}\text { Picea } \\
\text { abies } \\
\text { plantatio } \\
\text { n }\end{array}$ & Sweden & & & & $>12 \cdot 5$ & \\
\hline $\begin{array}{l}\text { Gusewell } \\
(2004)\end{array}$ & $\begin{array}{l}\text { Terrestri } \\
\text { al }\end{array}$ & Review & $\mathrm{N}$ and $\mathrm{P}$ & & & $<10$ & $>20$ \\
\hline $\begin{array}{l}\text { Soudzilovskaia } \\
\text { et al., (2005) }\end{array}$ & $\begin{array}{l}\text { Alpine } \\
\text { tundra }\end{array}$ & Russia & $\mathrm{N}$ and $\mathrm{P}$ & 29 & $\mathrm{~N}$ and $\mathrm{P}$ & & \\
\hline
\end{tabular}

Note: Revised from Tessier and Ravnal (2003) 


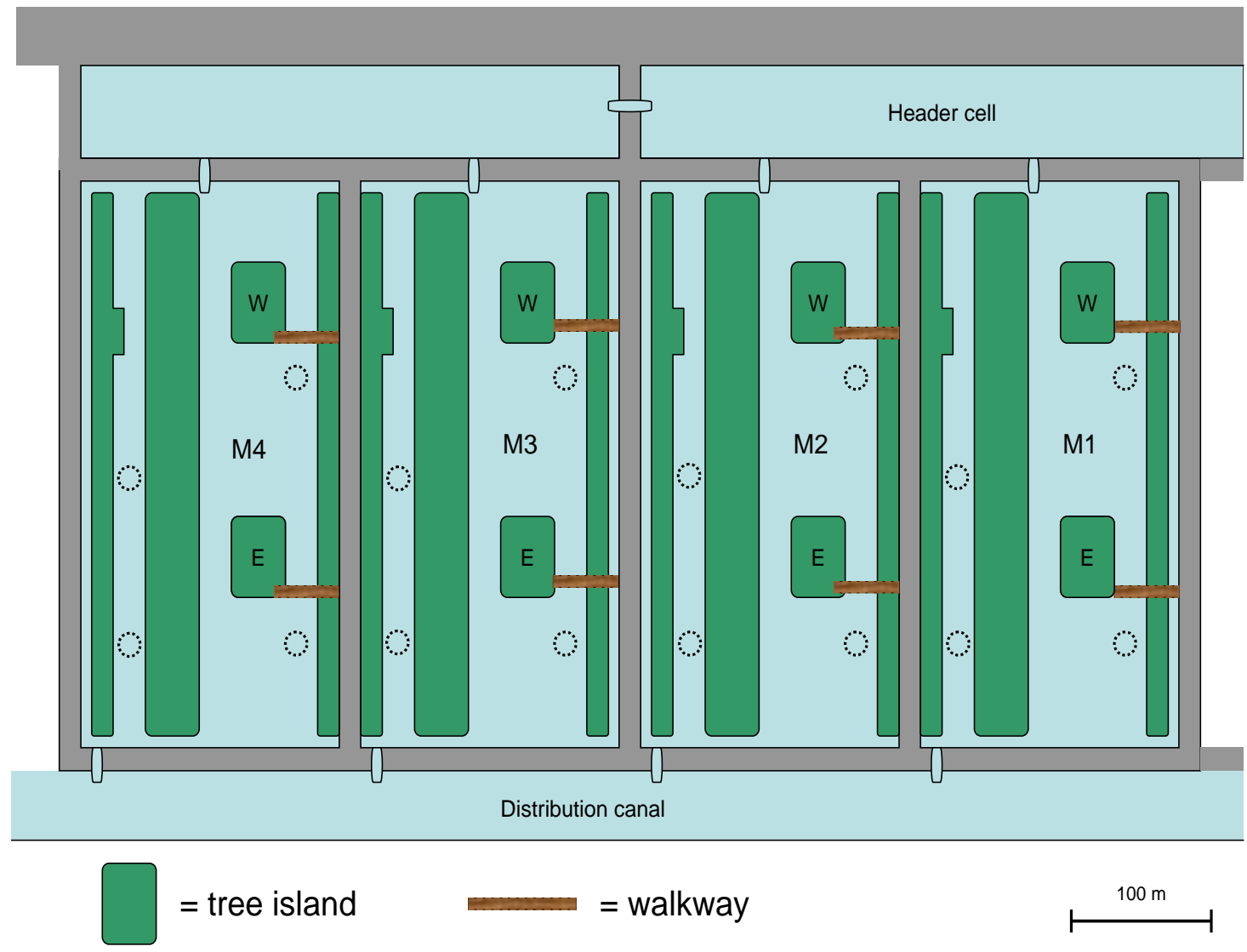

Figure 2. A map showing a design of LILA. Each macrocosm (M1-M4) contains two islands, $\mathrm{E}$ and $\mathrm{W}$; one of them made up of limestone while other was peat. 


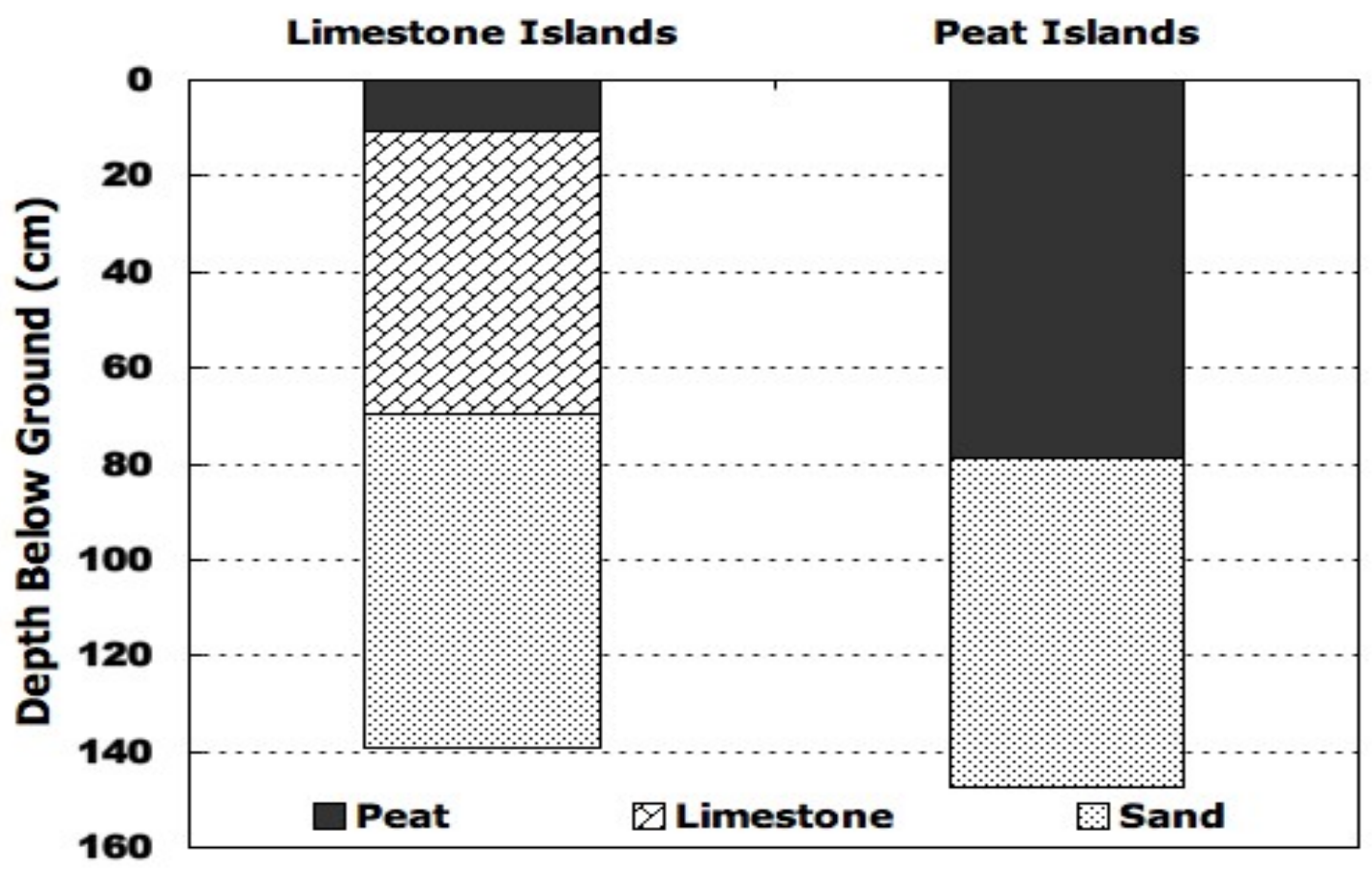

Figure 3. The average below ground depth $(\mathrm{m})$ of sediment detected at the center of the peat and limestone tree islands when the groundwater wells were installed. (Adopted from Stoffella et al., 2010) 


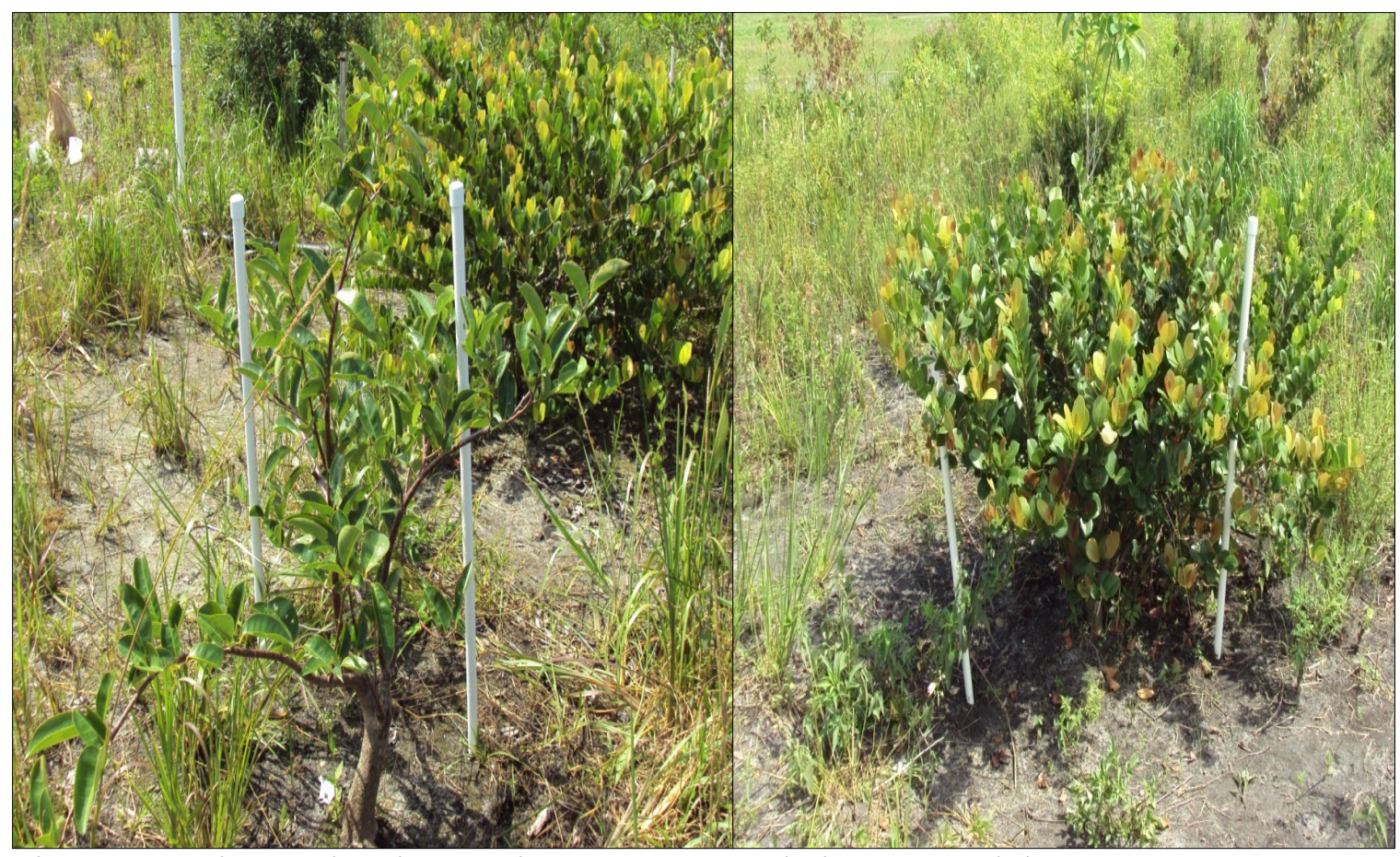

Figure 4. A picture showing nutrient treatment technique around the trees. 


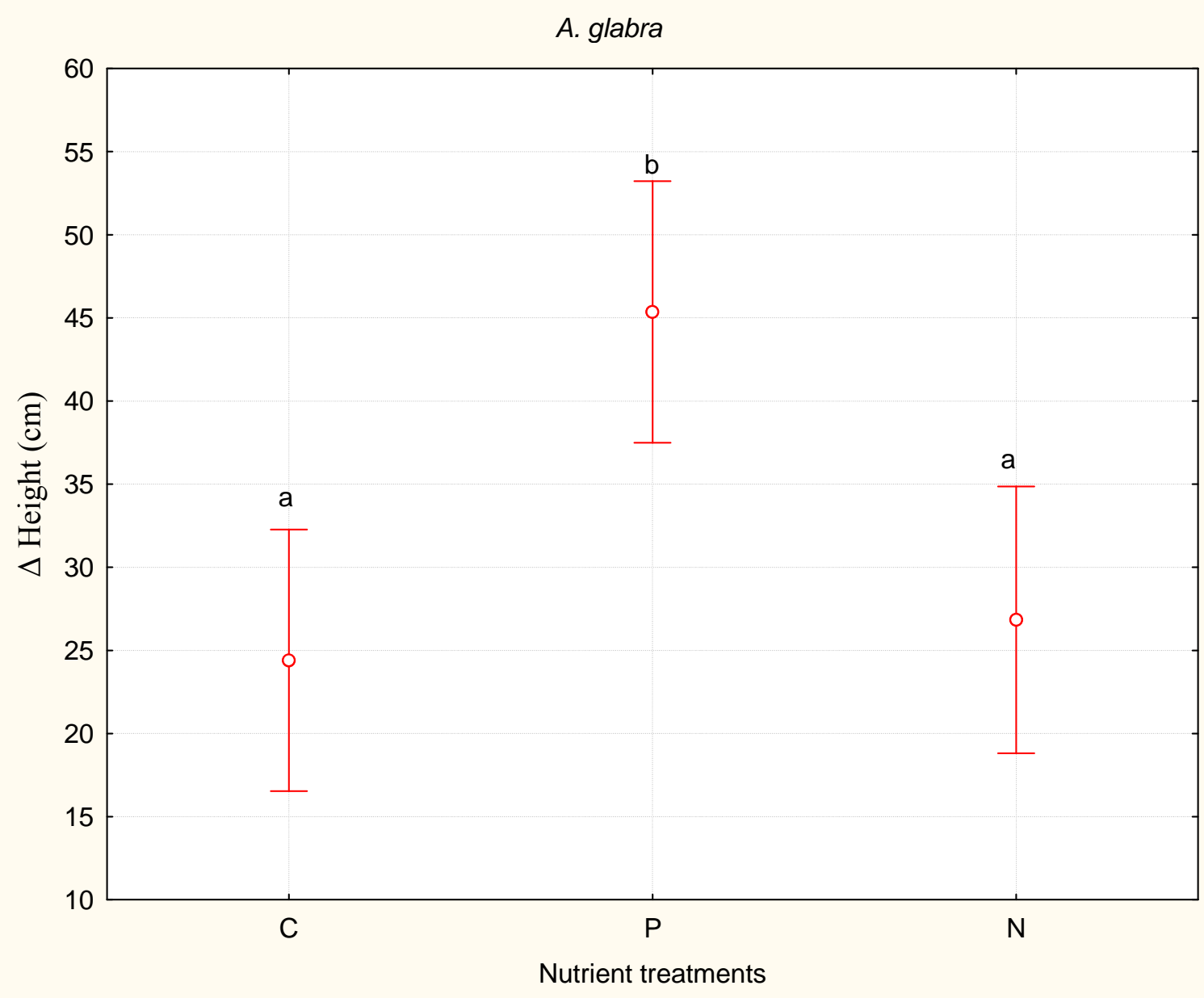

Figure 5. Comparisons of growth response between nutrient treatments for A. glabra. Each vertical bar represents $95 \%$ confidence interval. Nutrient treatments are $\mathrm{C}=$ Control, $\mathrm{P}=\mathrm{P}$-treatment, and $\mathrm{N}=\mathrm{N}$-treatment. Treatments whose labels include the same letter do not differ $(\mathrm{p}<0.05)$. 


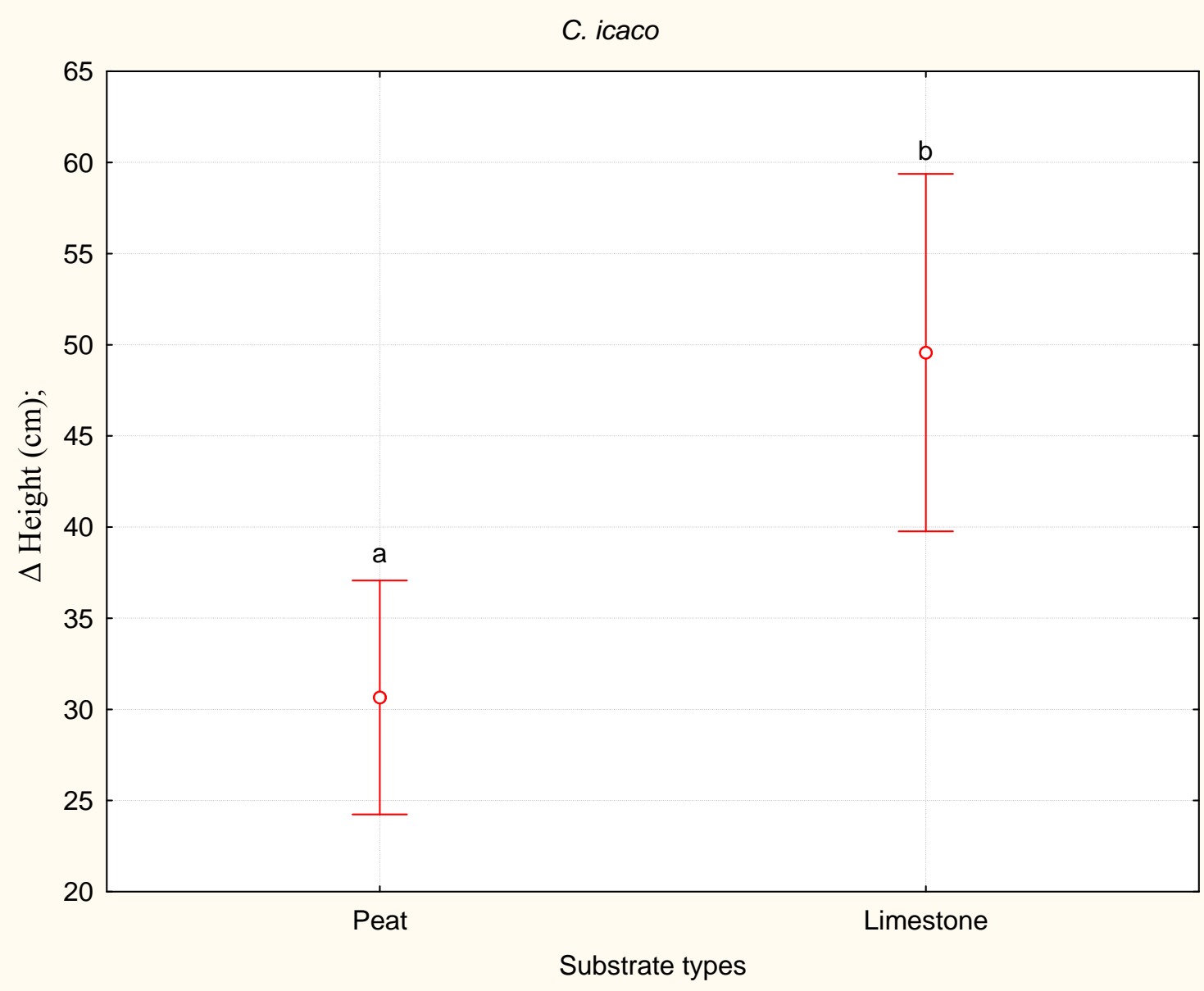

Figure 6. Comparisons of growth response for C. icaco on limestone and peat substrates. Each vertical bar represents $95 \%$ confidence interval. Substrates labeled same letter do not differ $(\mathrm{p}<0.05)$. 


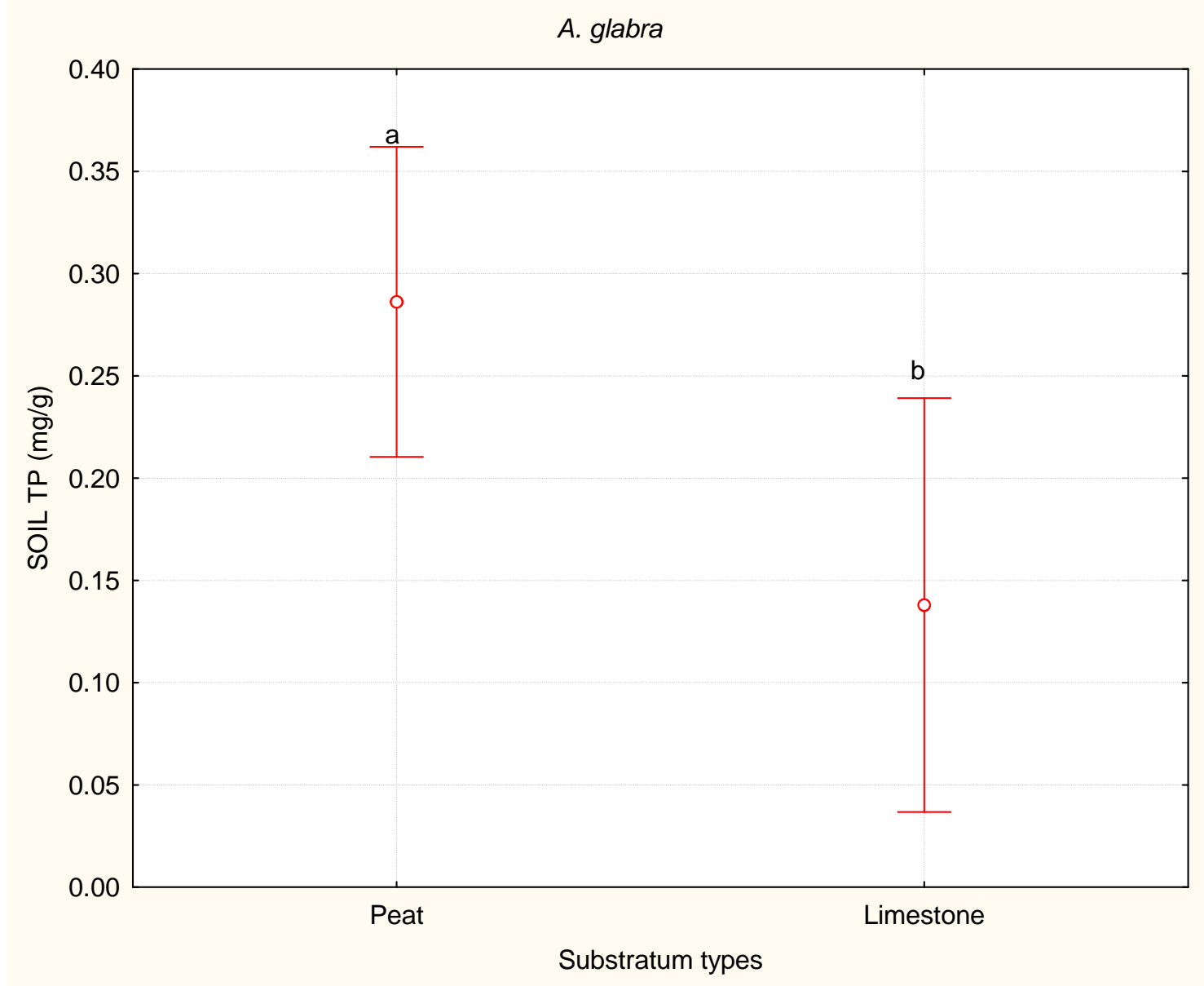

Figure 7. Comparisons of soil TP content for A. glabra on limestone and peat substrates. Each vertical bar represents $95 \%$ confidence interval. Treatments whose labels include the same letter do not differ $(\mathrm{p}<0.05)$. 


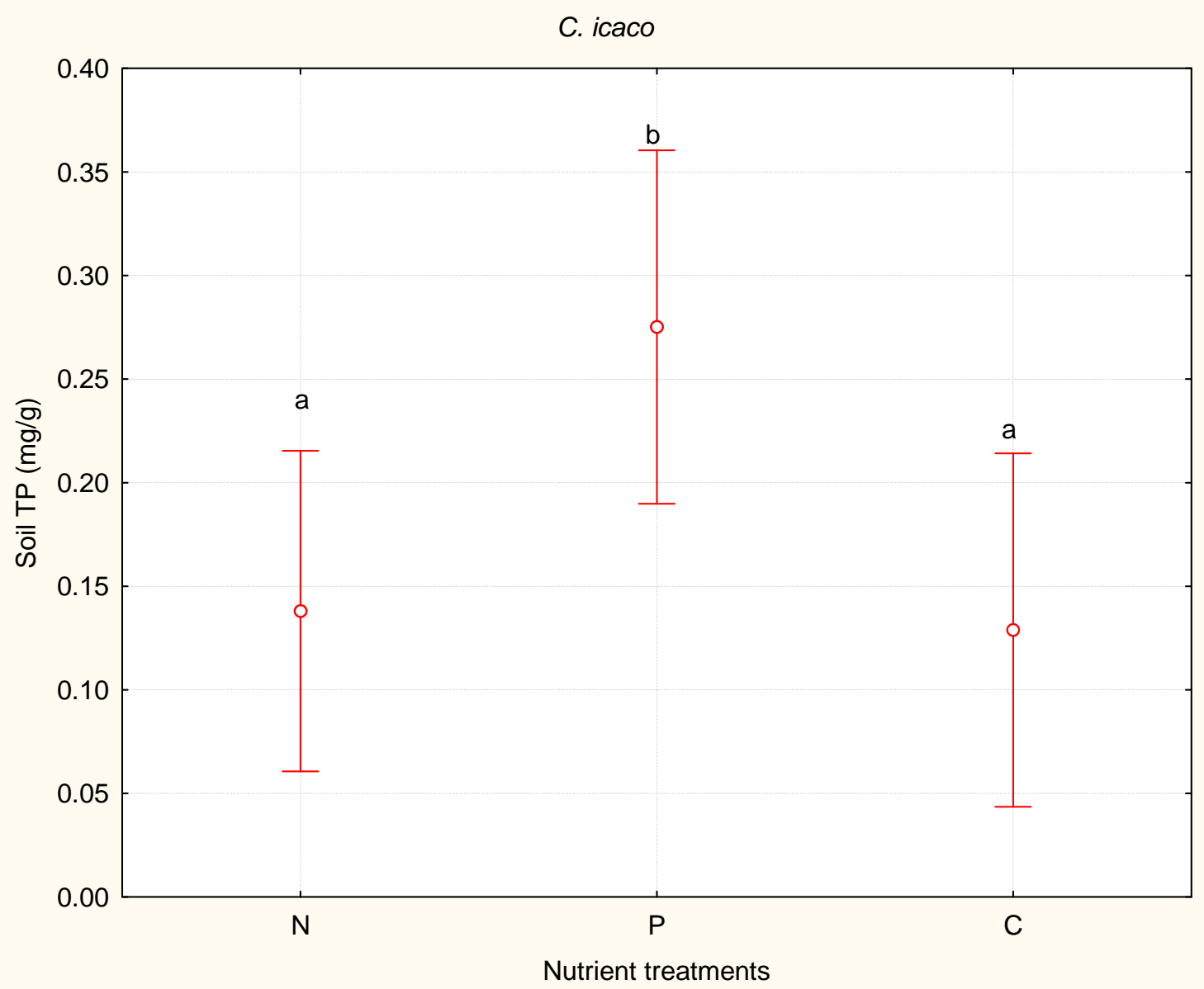

Figure 8. Comparisons of soil TP content between nutrient treatments for C. icaco on limestone and peat substrates. Each vertical bar represents $95 \%$ confidence interval. Nutrient treatments are $\mathrm{C}=\mathrm{Control}, \mathrm{P}=\mathrm{P}$-treatment, and $\mathrm{N}=\mathrm{N}$-treatment. Treatments whose labels include the same letter do not differ $(\mathrm{p}<0.05)$. 


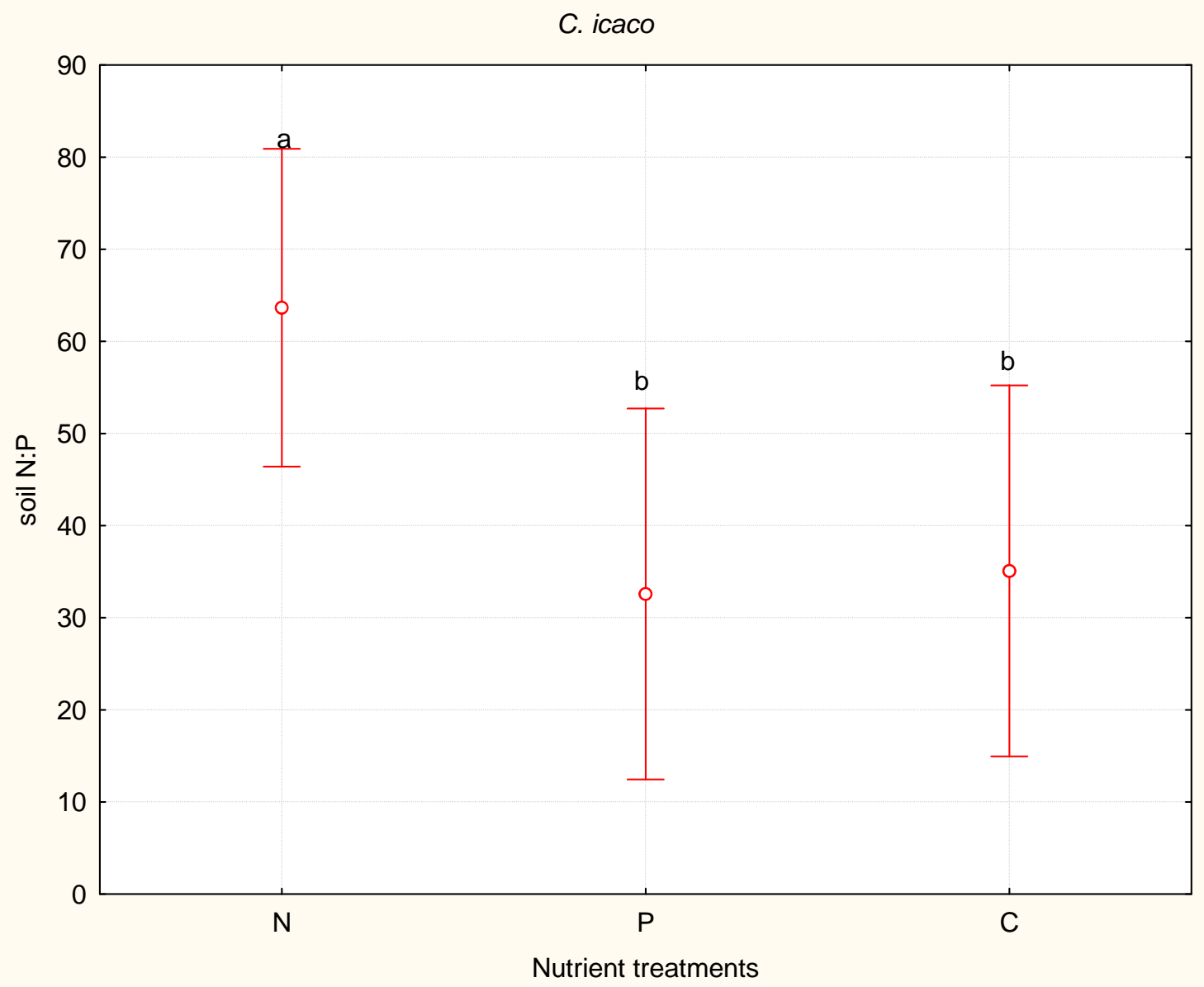

Figure 9. Comparisons of soil $\mathrm{N}: \mathrm{P}$ ratio between nutrient treatments for $C$. icaco on limestone and peat substrates. Each vertical bar represents $95 \%$ confidence interval. Nutrient treatments are $\mathrm{C}=\mathrm{Control}, \mathrm{P}=\mathrm{P}$-treatment, and $\mathrm{N}=\mathrm{N}$-treatment. Treatments whose labels include the same letter do not differ $(\mathrm{p}<0.05)$. 


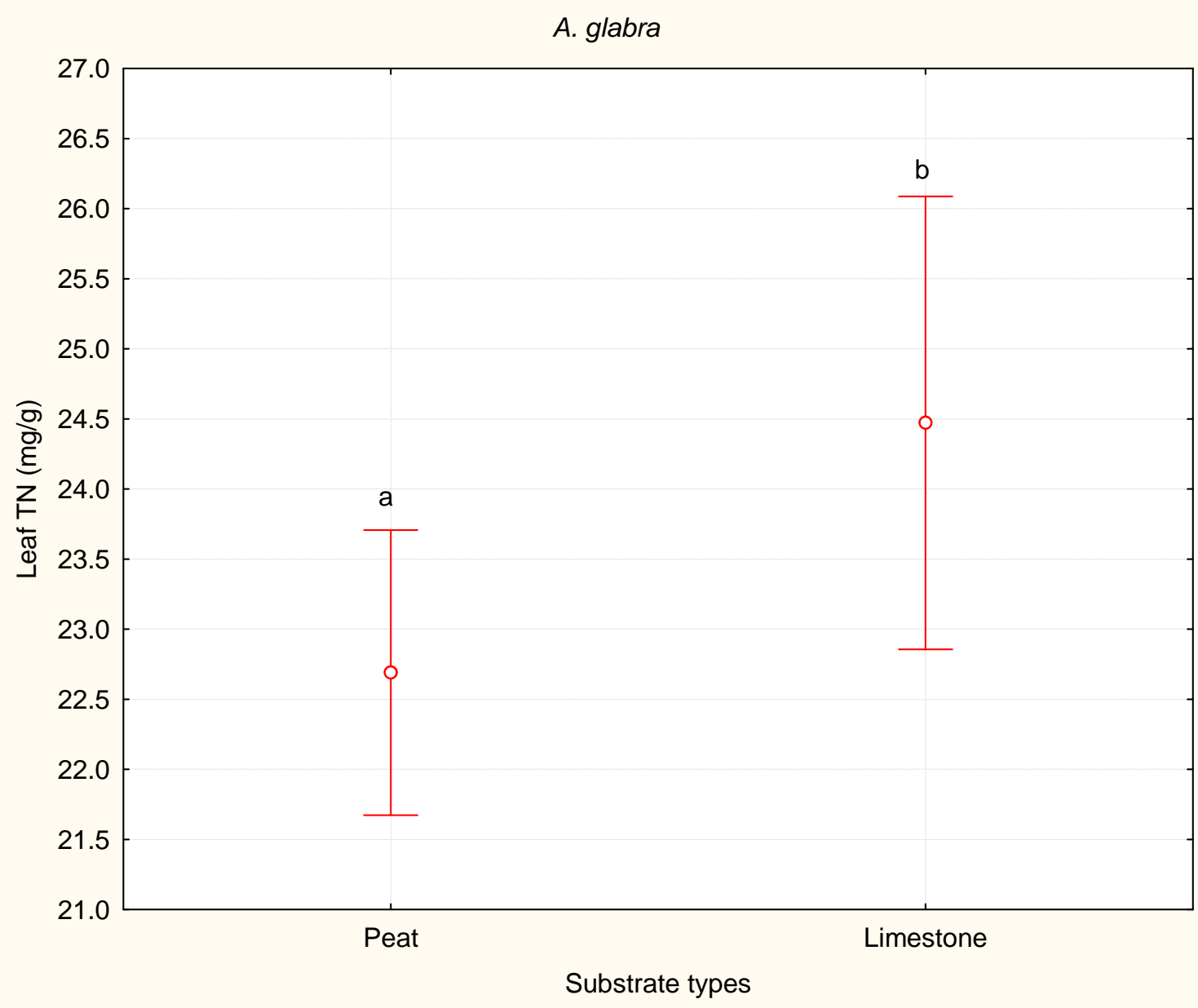

Figure 10. Comparisons of leaf TN for A. glabra on limestone and peat substrates. Each vertical bar represents $95 \%$ confidence interval. Treatments labeled with the same letter do not differ $(\mathrm{p}<0.05)$. 


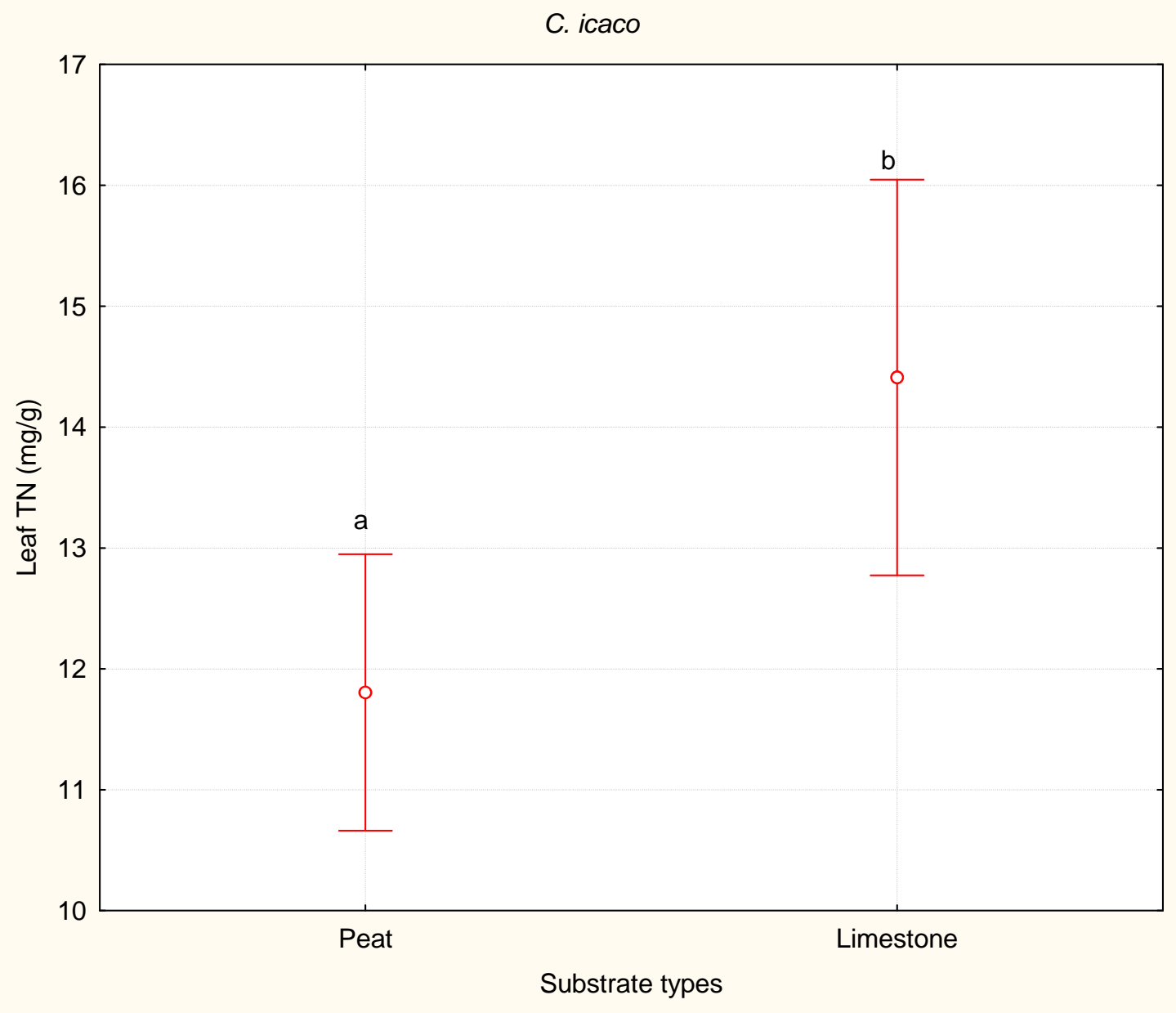

Figure 11. Comparison of leaf $\mathrm{TN}$ for $C$. icaco on limestone and peat substrates. Each vertical bar represents $95 \%$ confidence interval. Treatments labeled with the same letter do not differ $(\mathrm{p}<0.05)$. 


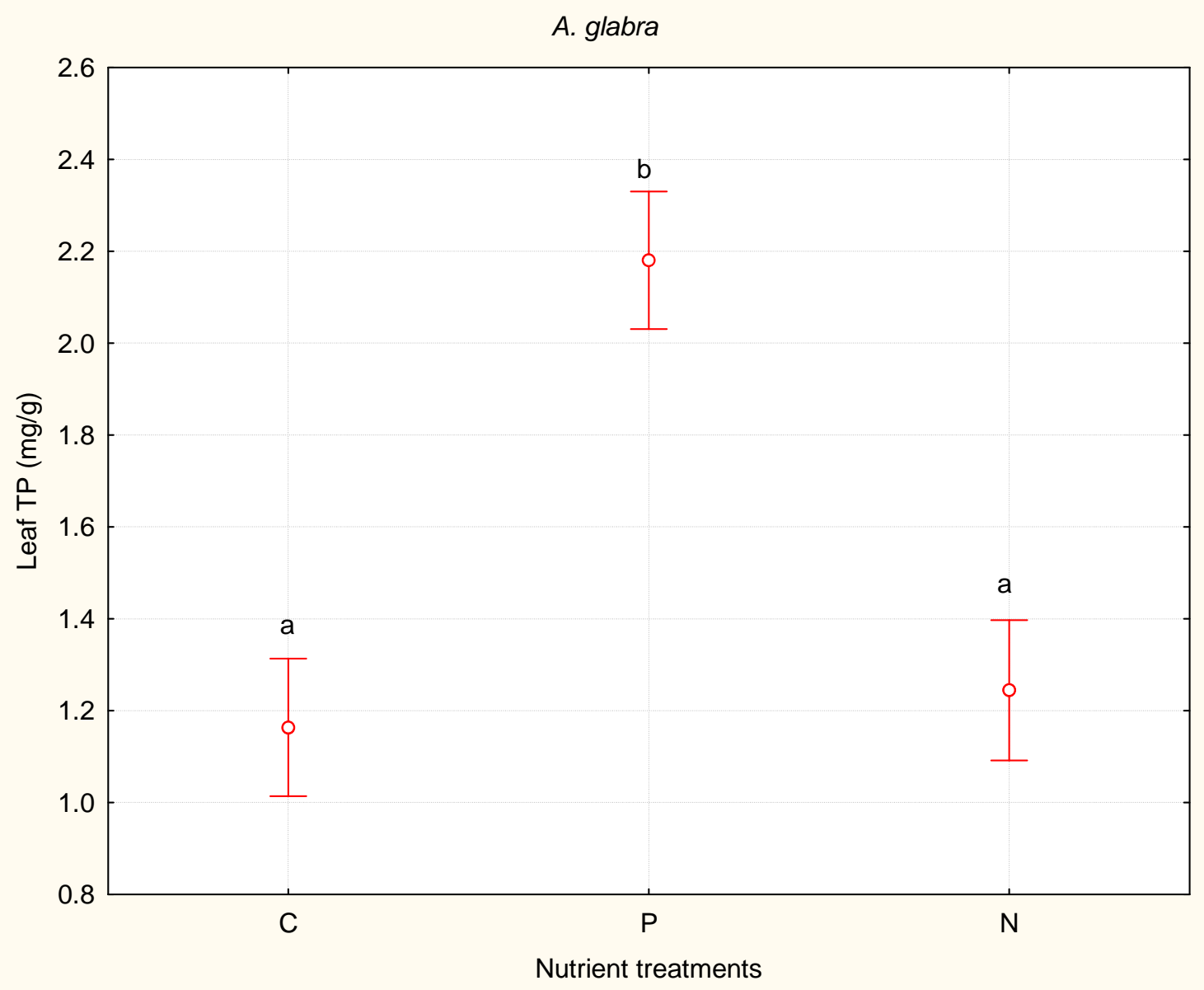

Figure 12. Comparisons of leaf TP between nutrient treatments for A. glabra on limestone and peat substrates. Each vertical bar represents $95 \%$ confidence interval. Nutrient treatments are $\mathrm{C}=\mathrm{Control}, \mathrm{P}=\mathrm{P}$-treatment, and $\mathrm{N}=\mathrm{N}$-treatment. Treatments whose labels include the same letter do not differ $(\mathrm{p}<0.05)$. 
C. icaco

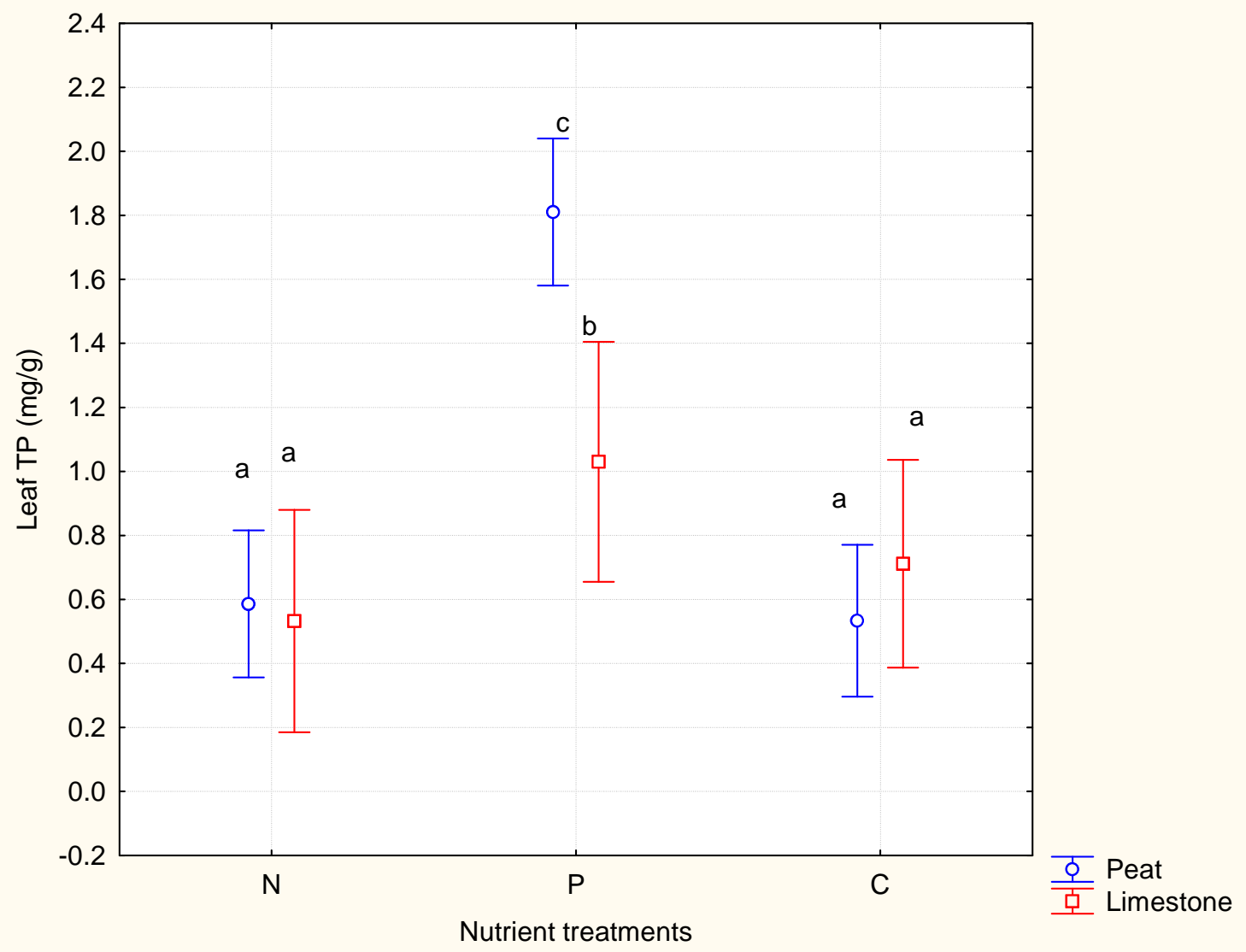

Figure 13. Comparisons of leaf TP between nutrient treatments for C. icaco on limestone and peat substrates. Each vertical bar represents $95 \%$ confidence interval. Nutrient treatments are $\mathrm{C}=\mathrm{Control}, \mathrm{P}=\mathrm{P}$-treatment, and $\mathrm{N}=\mathrm{N}$-treatment. Treatments whose labels include the same letter do not differ $(\mathrm{p}<0.05)$. 


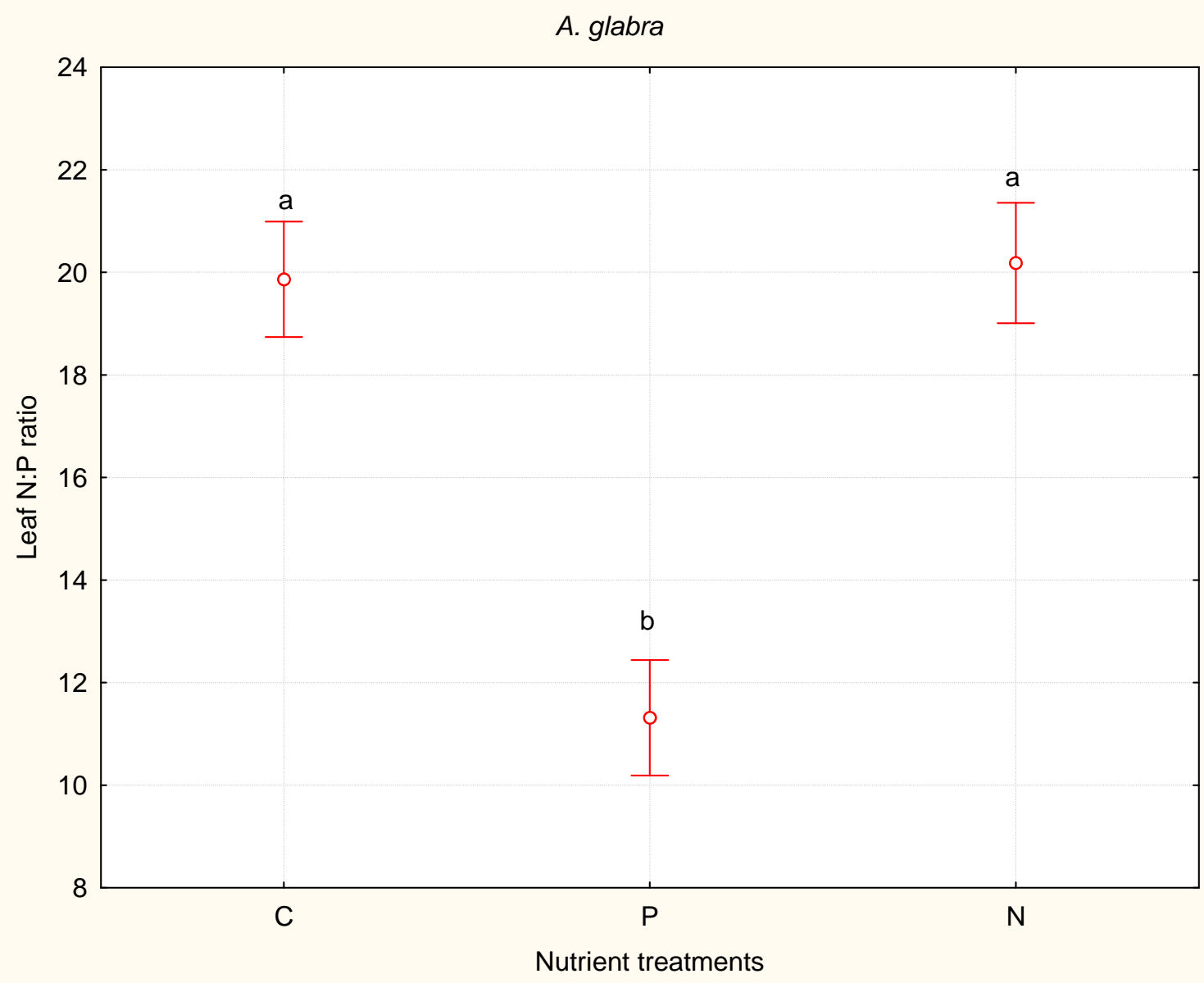

Figure 14. Comparisons of leaf $\mathrm{N}: \mathrm{P}$ between nutrient treatments for A. glabra on limestone and peat substrates. Each vertical bar represents $95 \%$ confidence interval. Nutrient treatments are $\mathrm{C}=$ Control, $\mathrm{P}=\mathrm{P}$-treatment, and $\mathrm{N}=\mathrm{N}$-treatment. Treatments whose labels include the same letter do not differ $(p<0.05)$ 


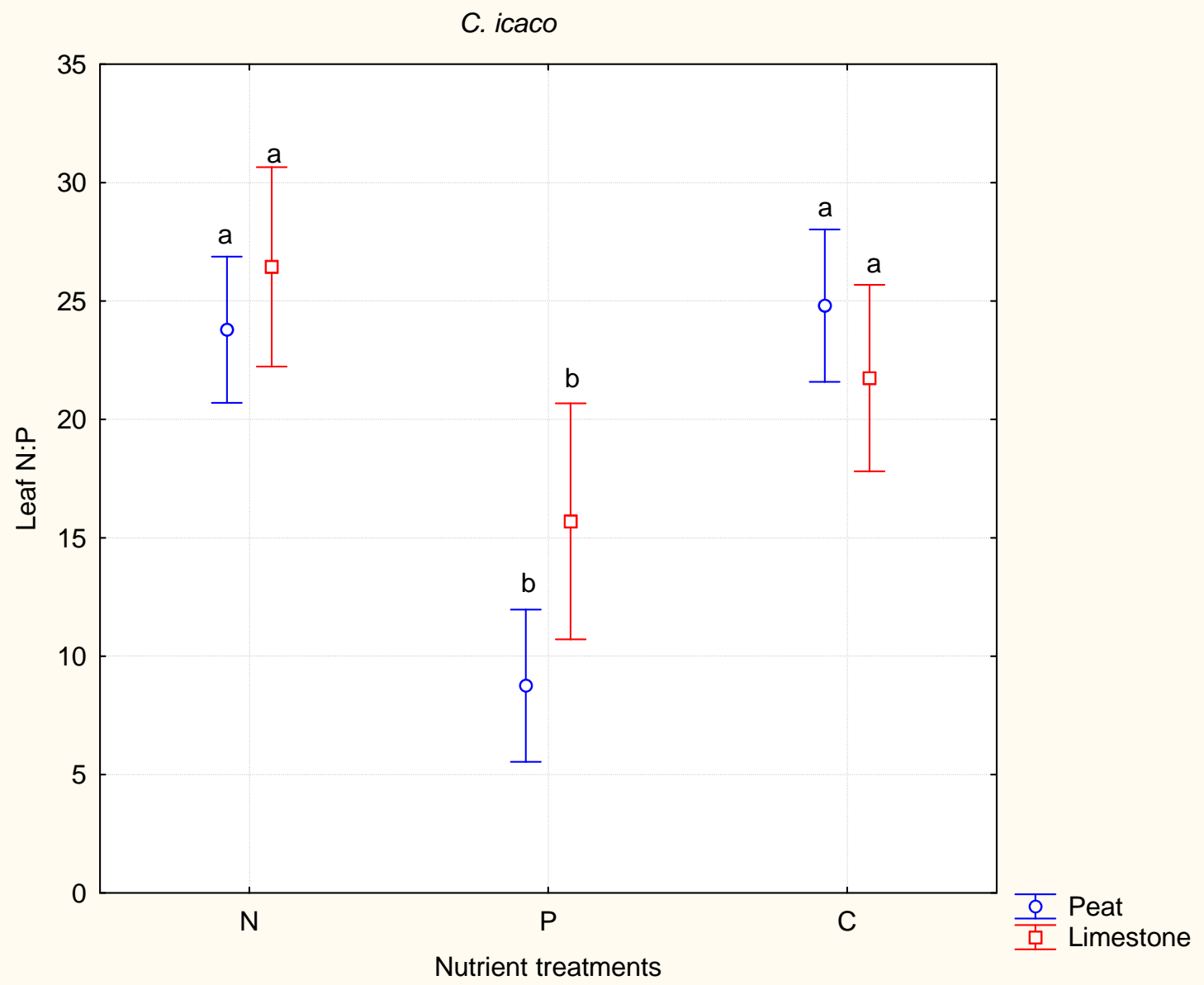

Figure 15. Comparisons of leaf $\mathrm{N}: \mathrm{P}$ ratio between nutrient treatments of $C$. icaco on limestone and peat substrates. Each vertical bar represents $95 \%$ confidence interval. Nutrient treatments are $\mathrm{C}=\mathrm{Control}, \mathrm{P}=\mathrm{P}$-treatment, and $\mathrm{N}=\mathrm{N}$-treatment. Treatments whose labels include the same letter do not differ $(\mathrm{p}<0.05)$. 


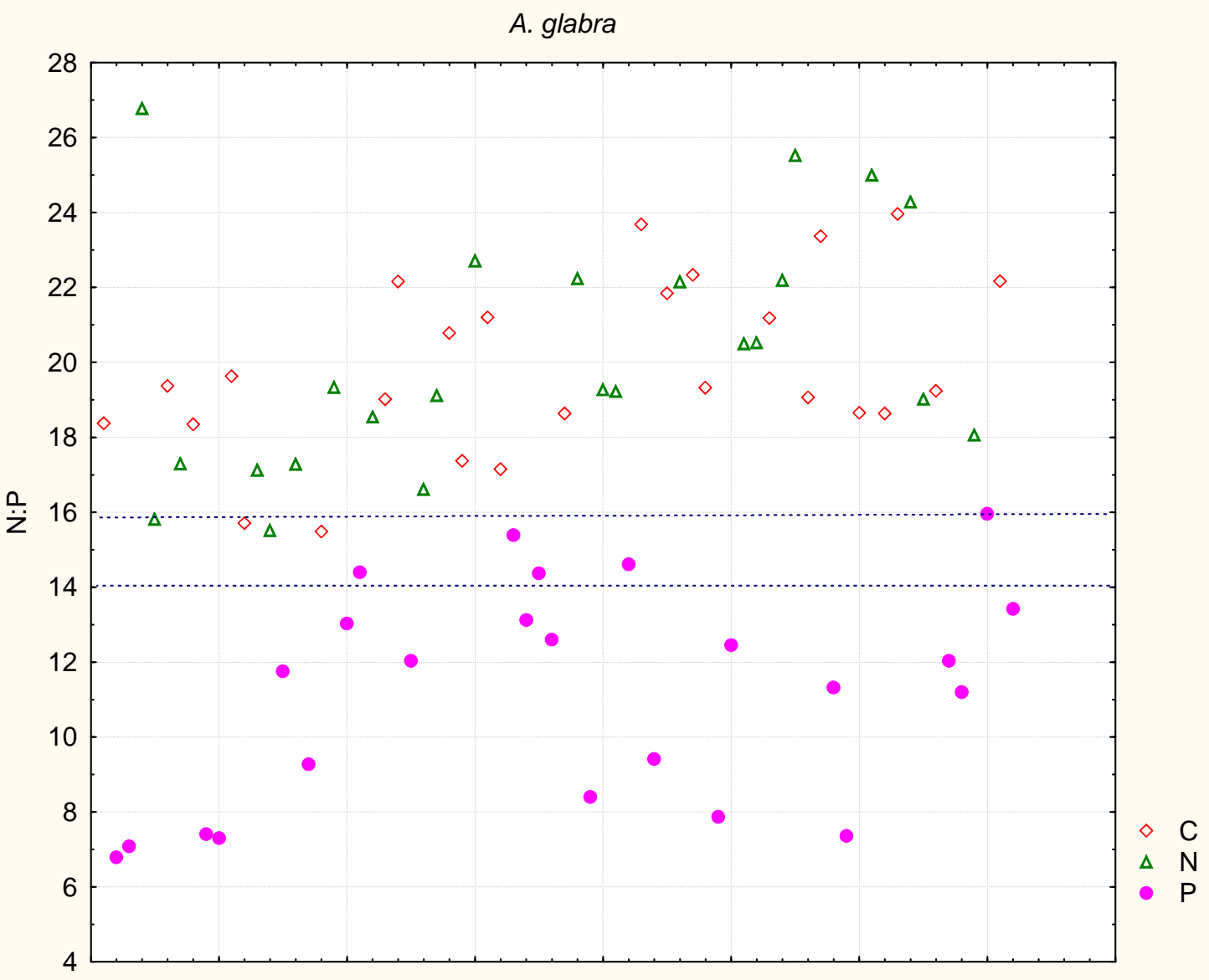

Figure 16. Scatterplot showing effect of nutrient treatment on N:P ratios for A. glabra. Nutrient treatments are $\mathrm{C}=\mathrm{Control}, \mathrm{P}=\mathrm{P}$-treatment, and $\mathrm{N}=\mathrm{N}$-treatment. Broken lines at the center of the graph showing $\mathrm{N}: \mathrm{P}$ critical ratios i.e. $>16$ and $<14$. 


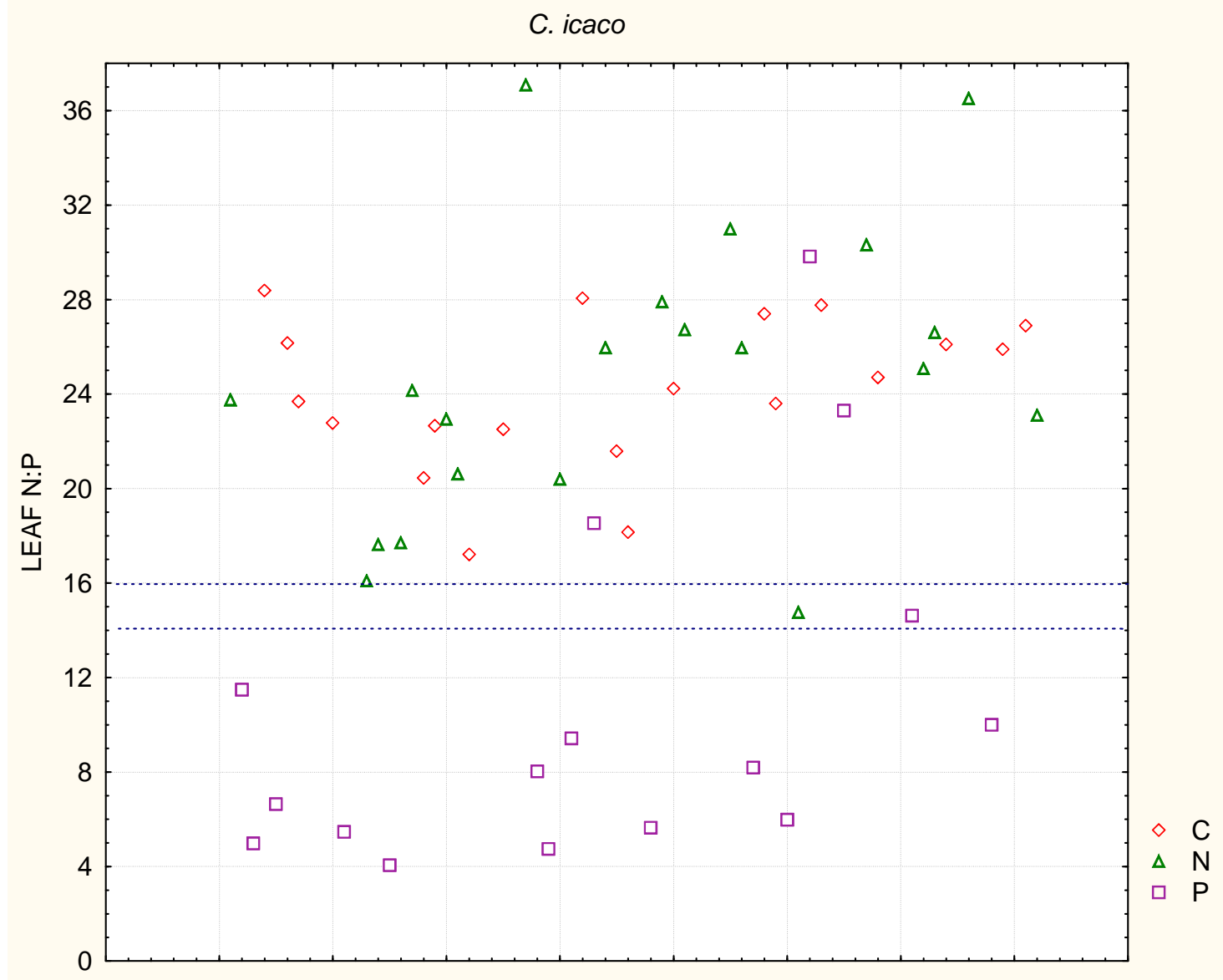

Figure 17. Scatterplot showing effect of nutrient treatment on $\mathrm{N}: \mathrm{P}$ ratios for $C$. icaco. Broken lines at the center of the graph showing N:P critical ratios i.e. $>16$ and $<14$. Nutrient treatments are $\mathrm{C}=$ Control, $\mathrm{P}=\mathrm{P}$-treatment, and $\mathrm{N}=\mathrm{N}$-treatment. 
A. glabra

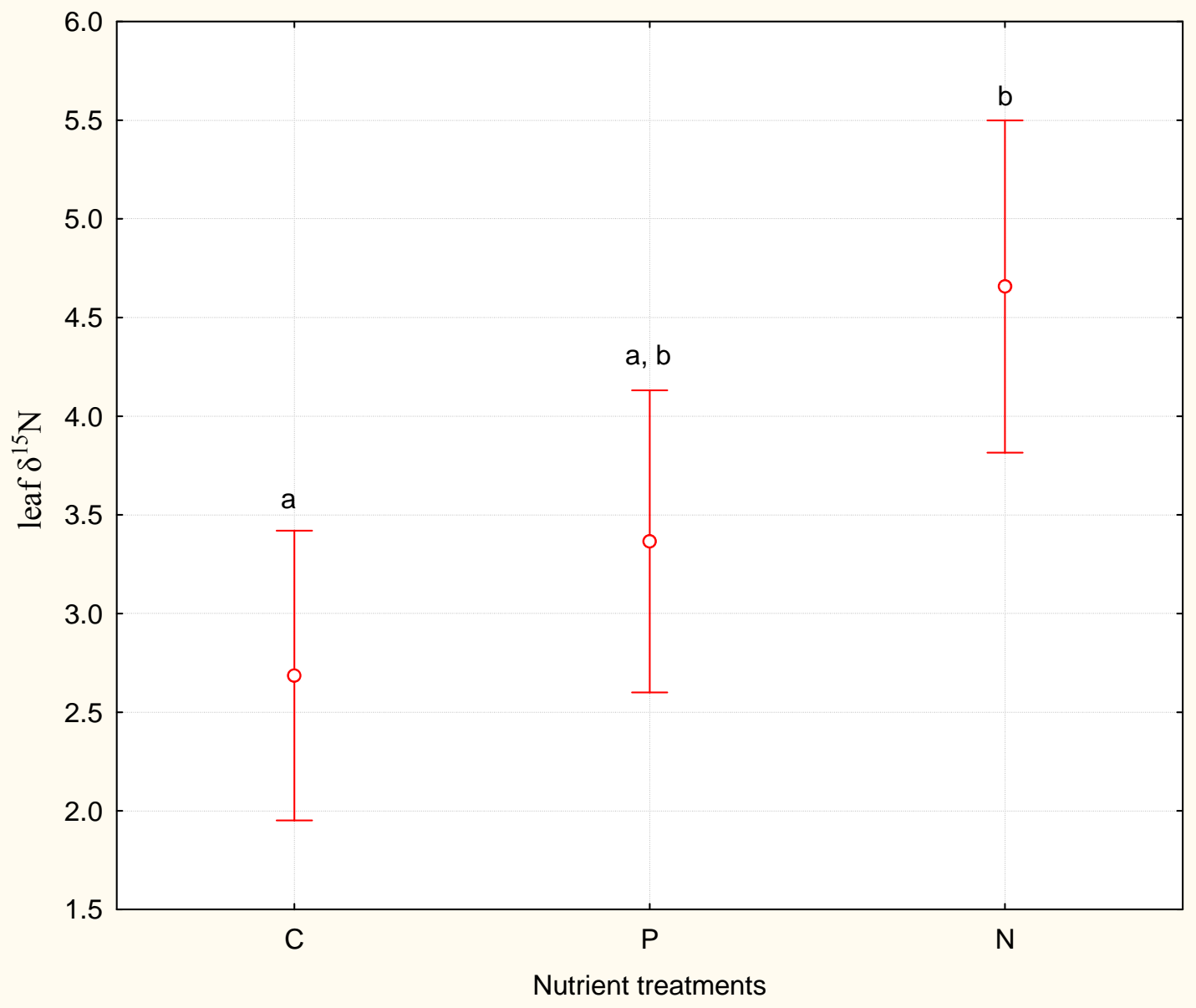

Figure 18. Comparisons of leaf $\delta^{15} \mathrm{~N}$ between nutrient treatments for A. glabra on limestone and peat substrates. Each vertical bar represents $95 \%$ confidence interval. Nutrient treatments are $\mathrm{C}=\mathrm{Control}, \mathrm{P}=\mathrm{P}$-treatment, and $\mathrm{N}=\mathrm{N}$-treatment. Treatments whose labels include the same letter do not differ $(\mathrm{p}<0.05)$. 
C. icaco

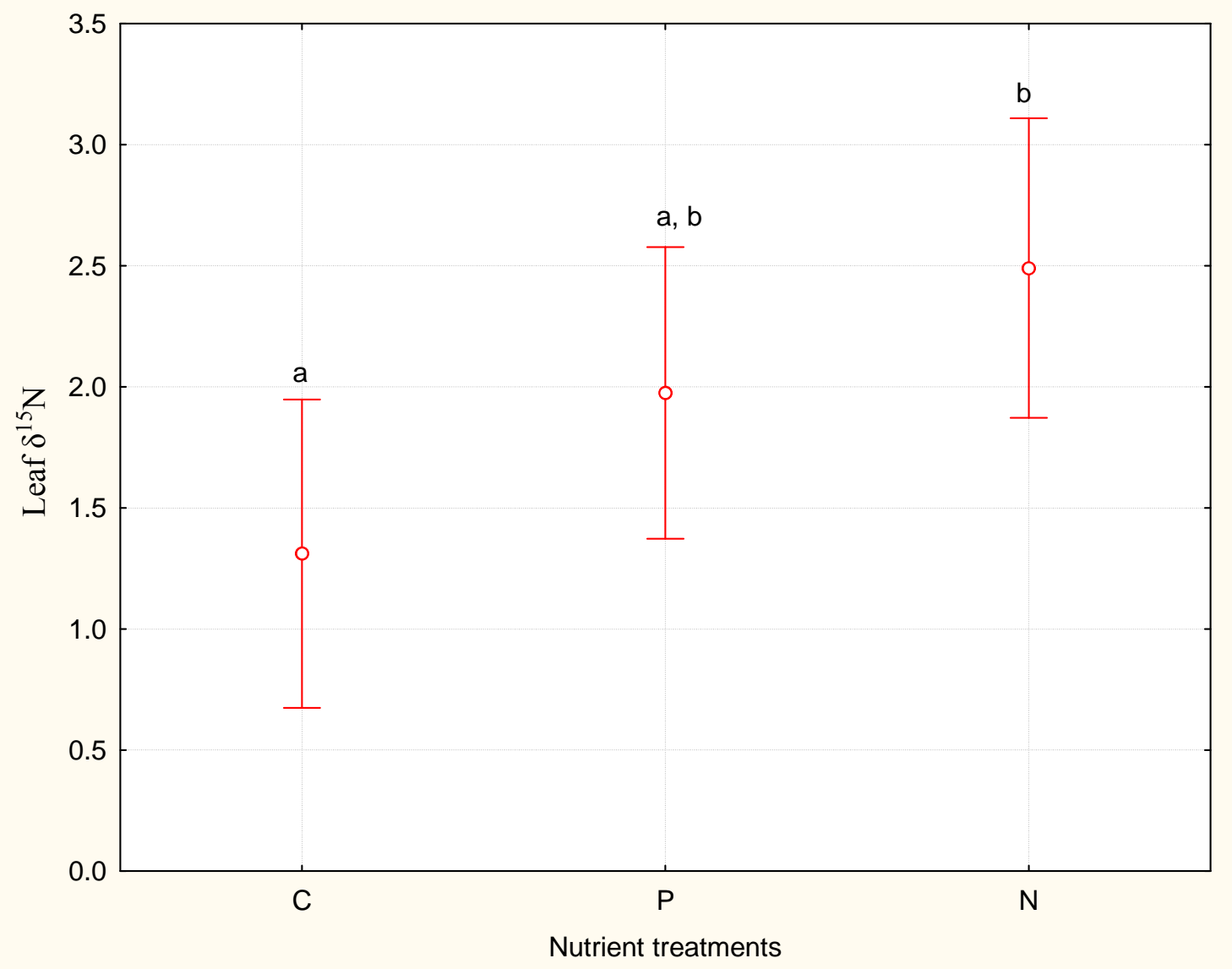

Figure 19. Comparisons of leaf $\delta^{15} \mathrm{~N}$ between nutrient treatments for $C$. icaco on limestone and peat substrates. Each vertical bar represents $95 \%$ confidence interval. Nutrient treatments are $\mathrm{C}=\mathrm{Control}, \mathrm{P}=\mathrm{P}$-treatment, and $\mathrm{N}=\mathrm{N}$-treatment. Treatments whose labels include the same letter do not differ $(\mathrm{p}<0.05)$. 


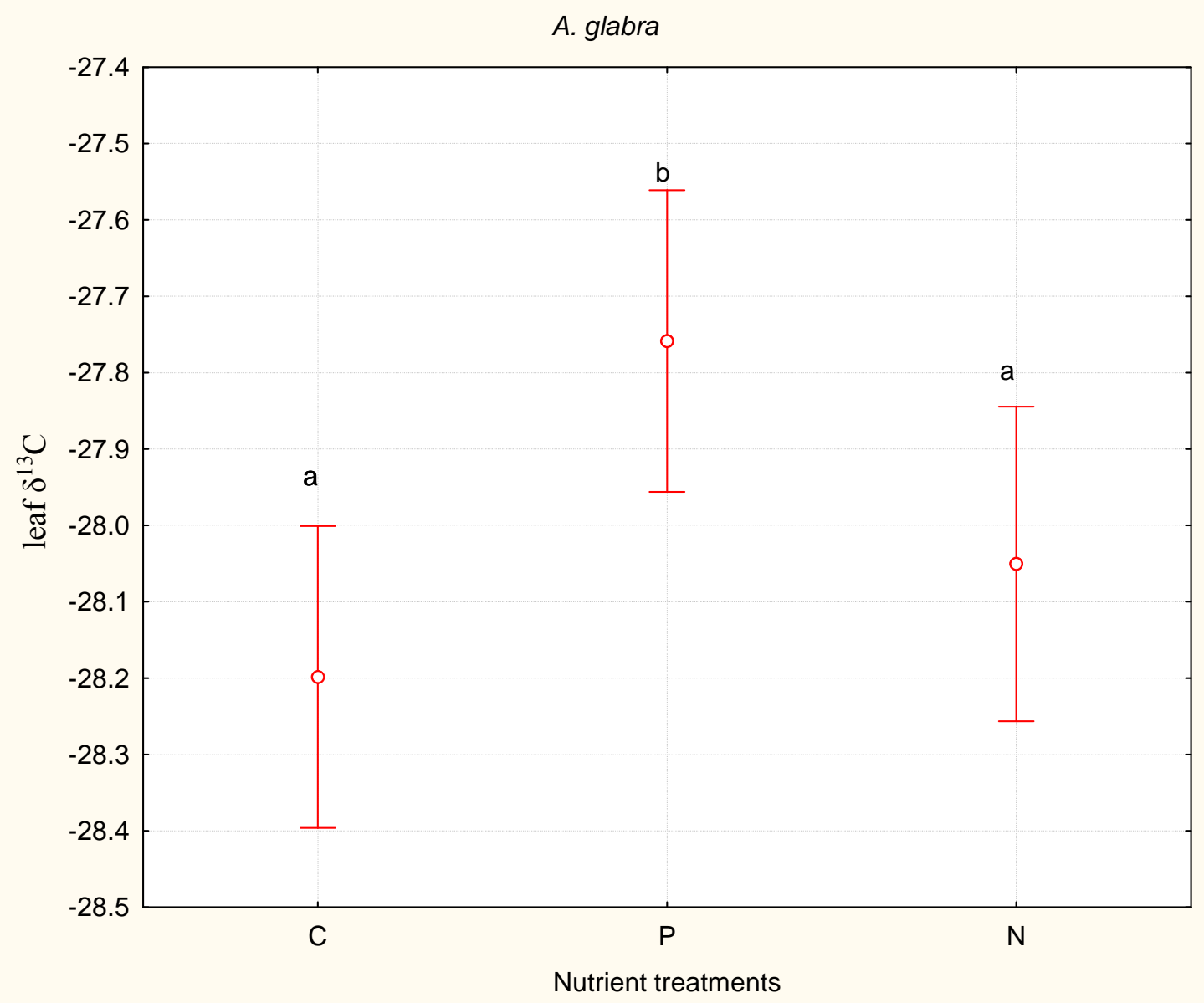

Figure 20. Comparisons of leaf $\delta^{13} \mathrm{C}$ between nutrient treatments of A. glabra on limestone and peat substrates. Each vertical bar represents $95 \%$ confidence interval. Nutrient treatments are $\mathrm{C}=\mathrm{Control}, \mathrm{P}=\mathrm{P}$-treatment, and $\mathrm{N}=\mathrm{N}$-treatment. Treatments whose labels include the same letter do not differ $(\mathrm{p}<0.05)$. 


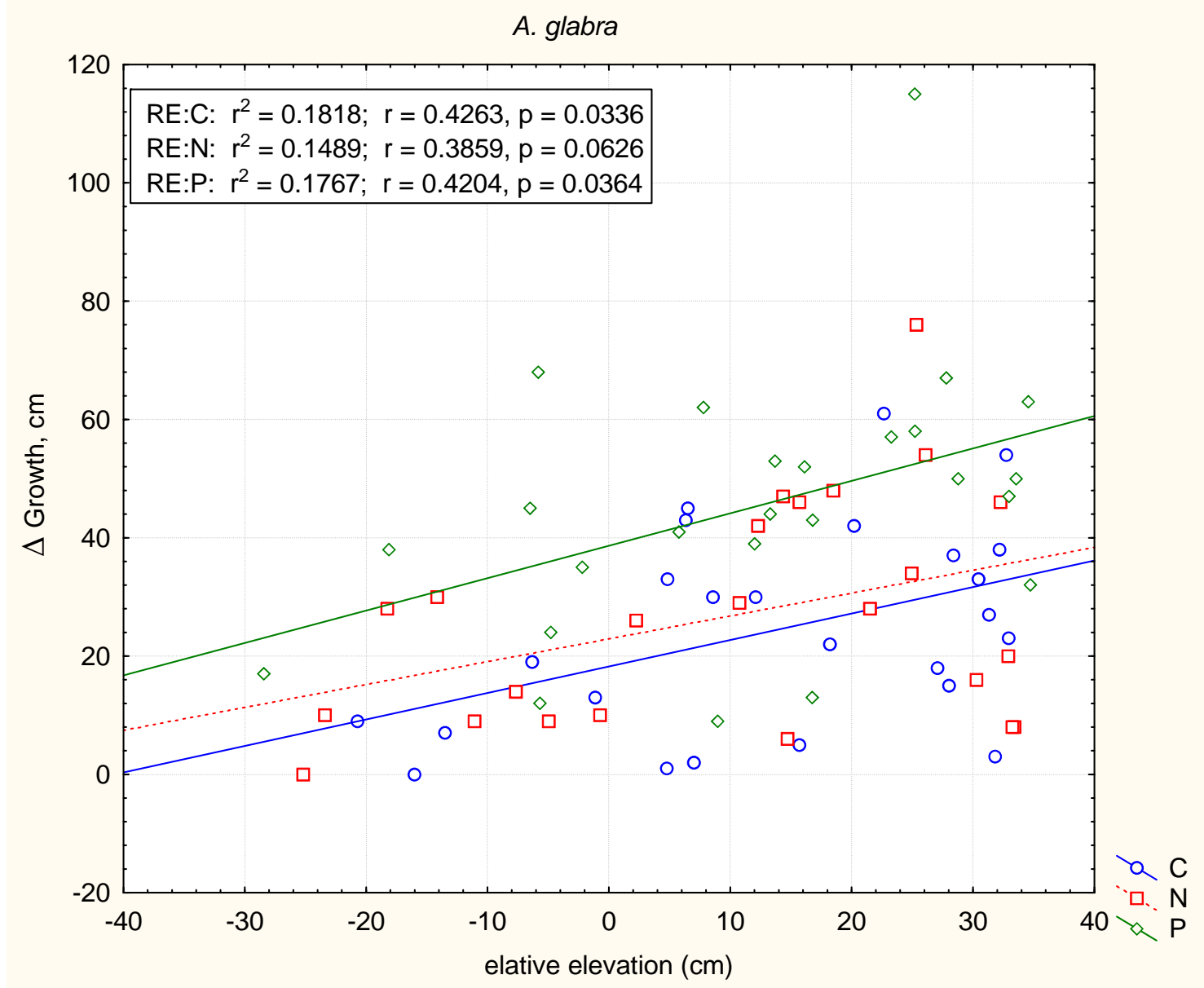

Figure 21. A scatterplot between growth response of $\mathrm{C}, \mathrm{N}$, and P-treatment of A. glabra trees and relative elevation (RE). Solid lines are showing significant patterns, whereas broken lines are for non-significant. 


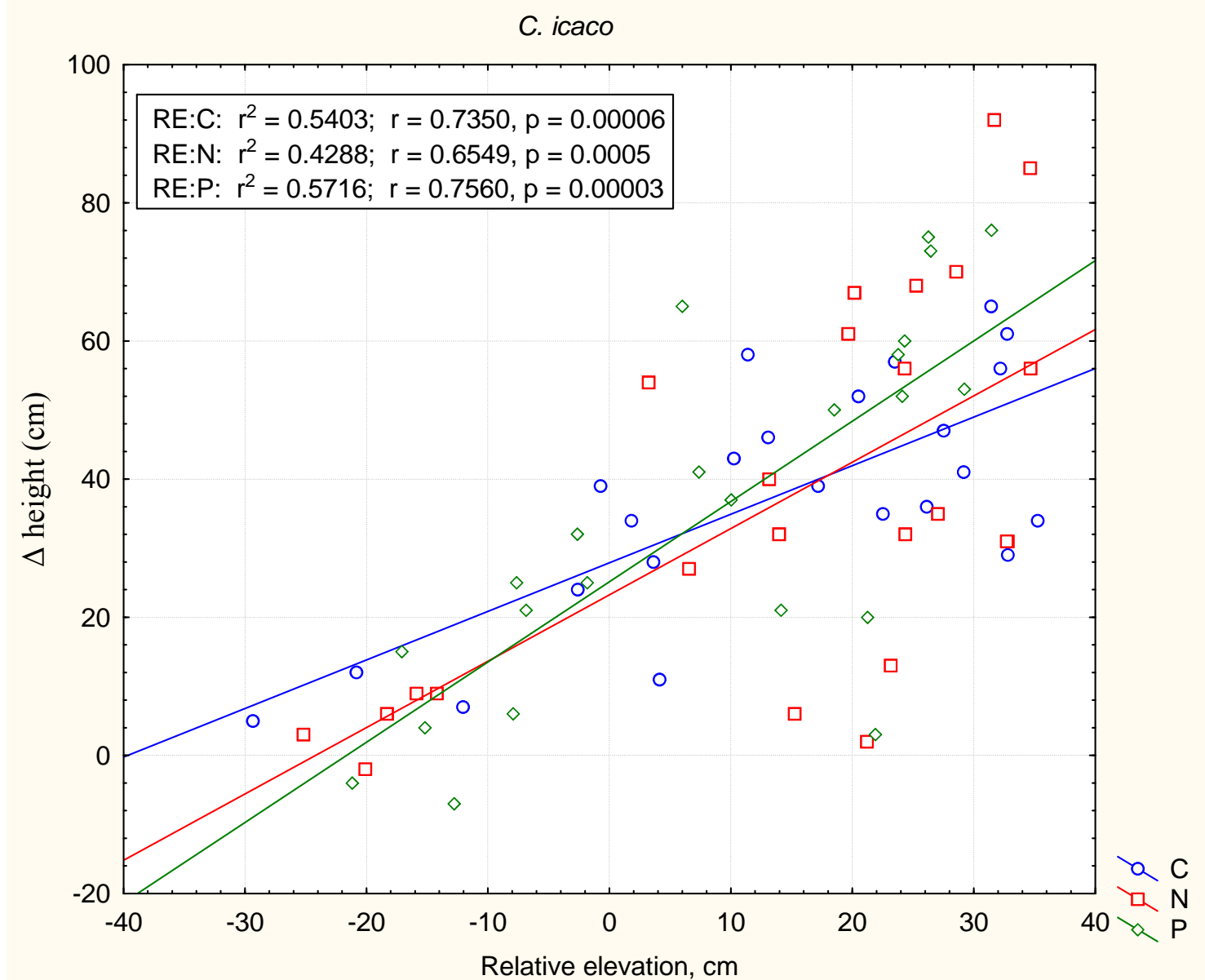

Figure 22. A scatterplot between growth response of $\mathrm{C}, \mathrm{N}$, and P-treatment of C. icaco trees and relative elevation (RE). Solid lines are showing significant patterns. 


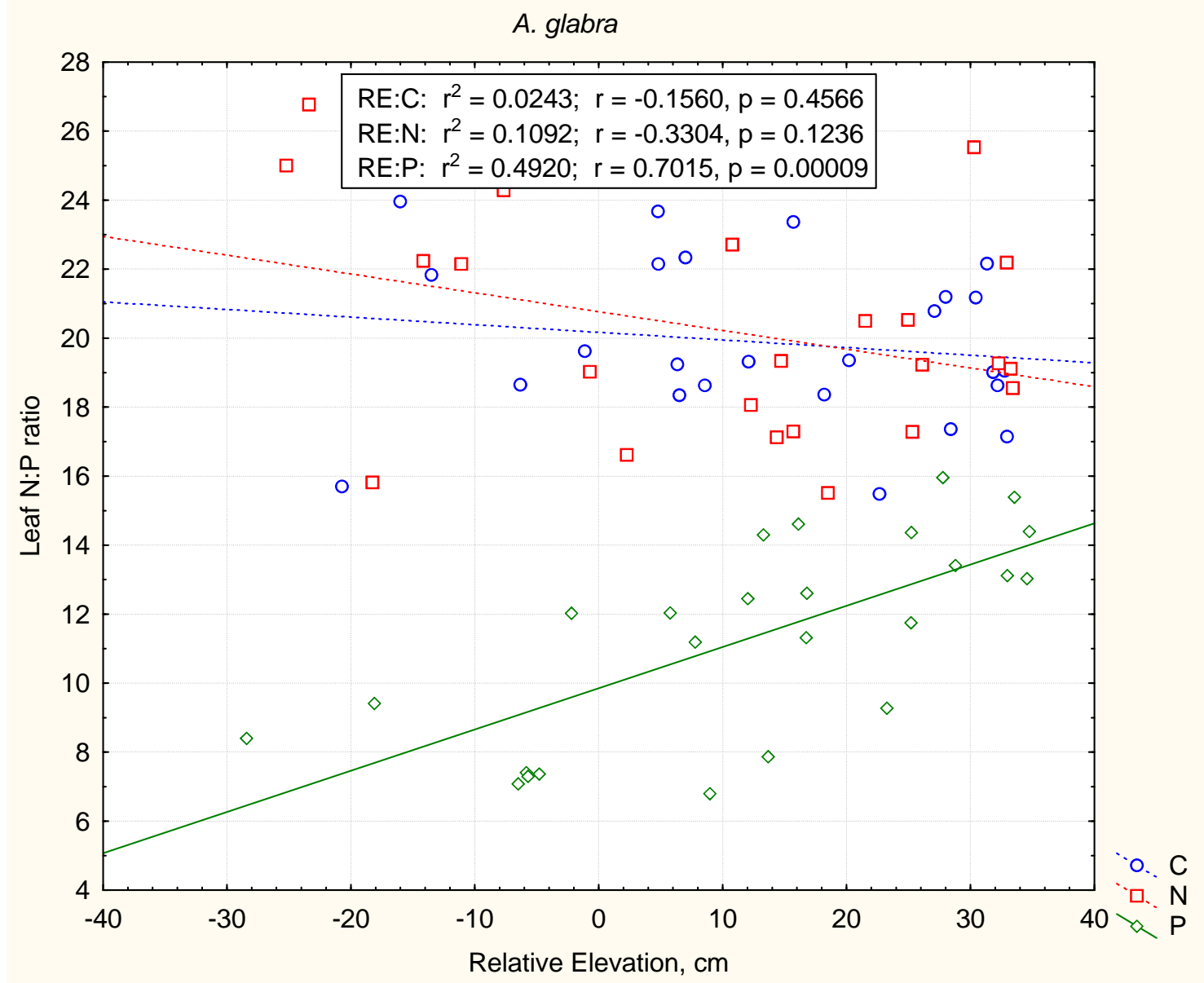

Figure 23. A scatterplot between leaf $\mathrm{N}: \mathrm{P}$ ratios of $\mathrm{C}, \mathrm{N}$, and P-treatment of $A$. glabra trees and relative elevation (RE). Solid lines are showing significant patterns, whereas broken lines are for non-significant. 


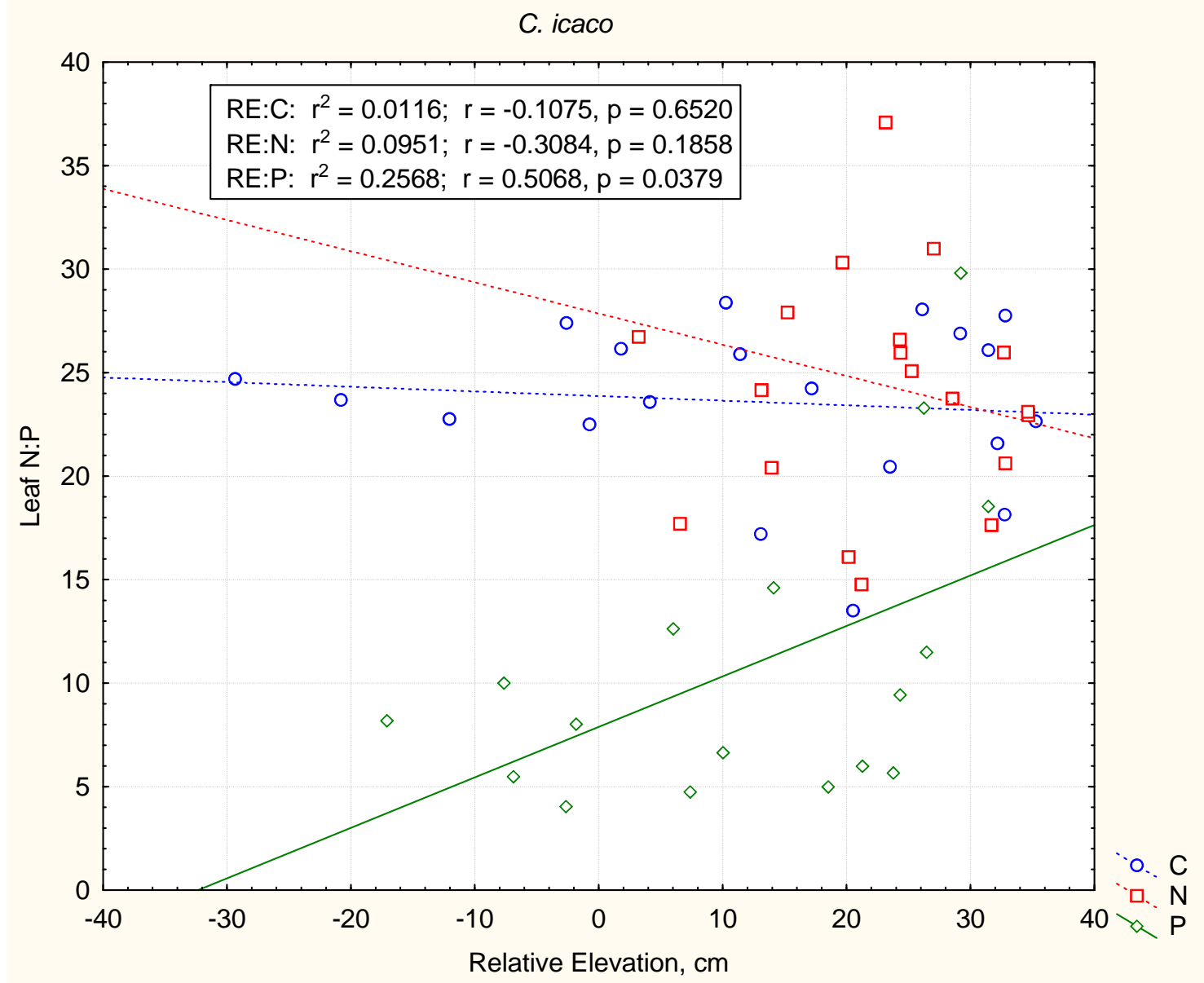

Figure 24. A scatterplot between leaf N:P ratios of C, N, and P-treatment of C. icaco trees and relative elevation (RE). Solid lines are showing significant patterns, whereas broken lines are for non-significant. 


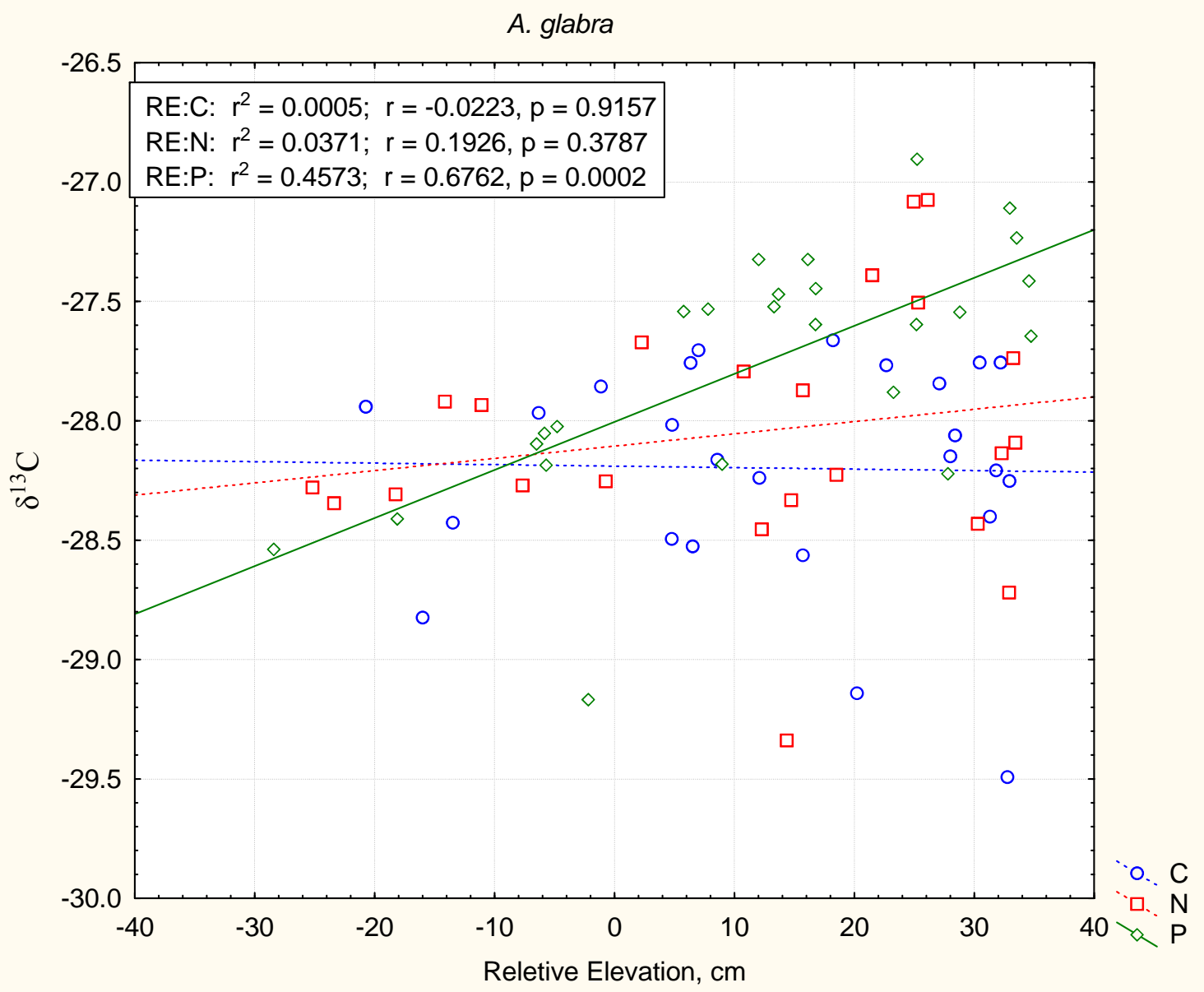

Figure 25. A scatterplot between leaf $\delta^{13} \mathrm{C}$ of C, N, and P-treatment of A. glabra trees and relative elevation (RE). Solid lines are showing significant patterns, whereas broken lines are for non-significant. 


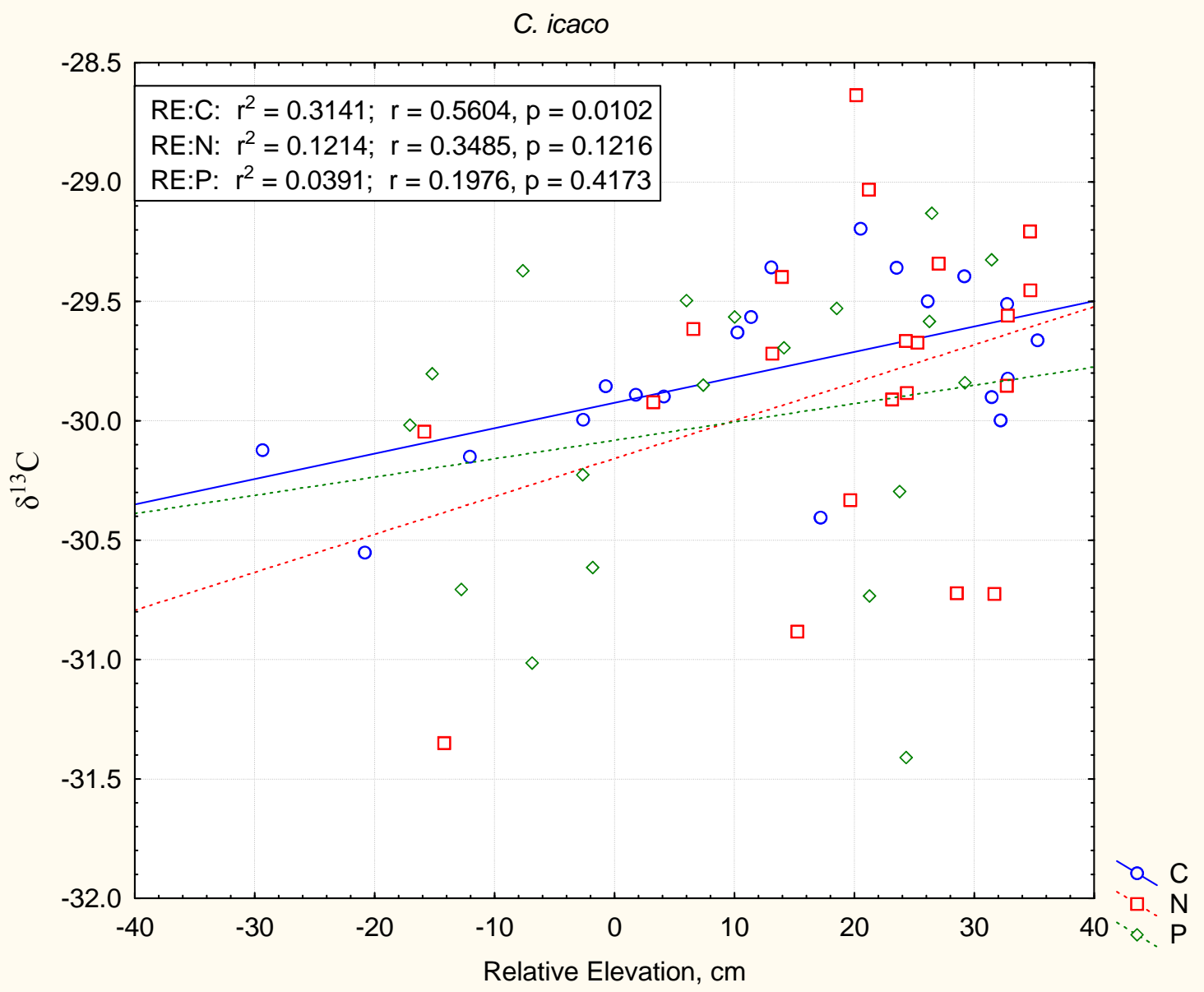

Figure 26. A scatterplot between leaf $\delta^{13} \mathrm{C}$ of $\mathrm{C}, \mathrm{N}$, and P-treatment of C. icaco trees and relative elevation (RE). Solid lines are showing significant patterns, whereas broken lines are for non-significant. 


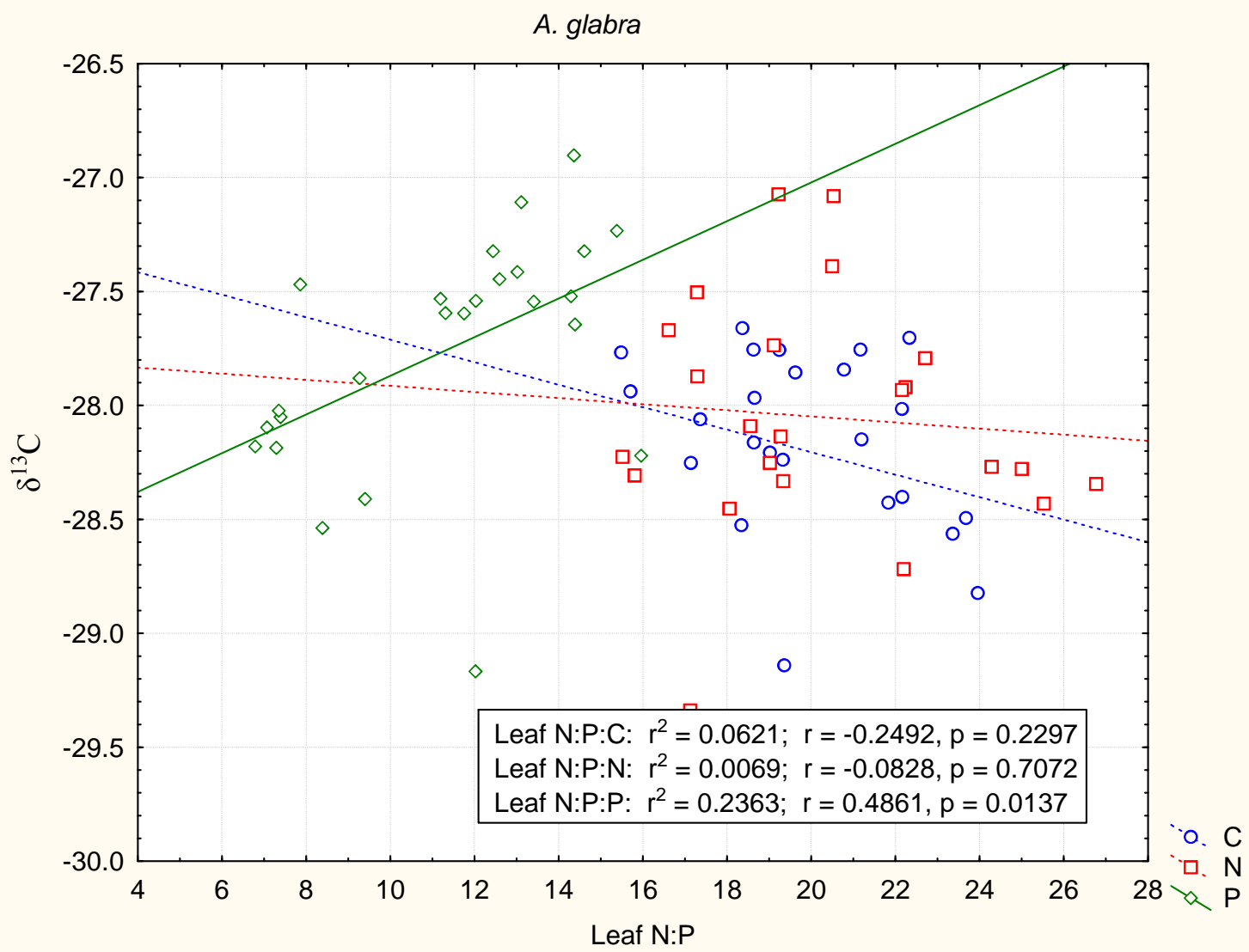

Figure 27. A scatterplot between leaf $\mathrm{N}: \mathrm{P}$ ratios and $\delta^{13} \mathrm{C}$ of $\mathrm{C}, \mathrm{N}$, and P-treatment of $A$. glabra trees. Control(C) and $\mathrm{N}$-treated $(\mathrm{N})$ did not show any significant pattern. Solid lines are showing significant patterns, whereas broken lines are for nonsignificant. 


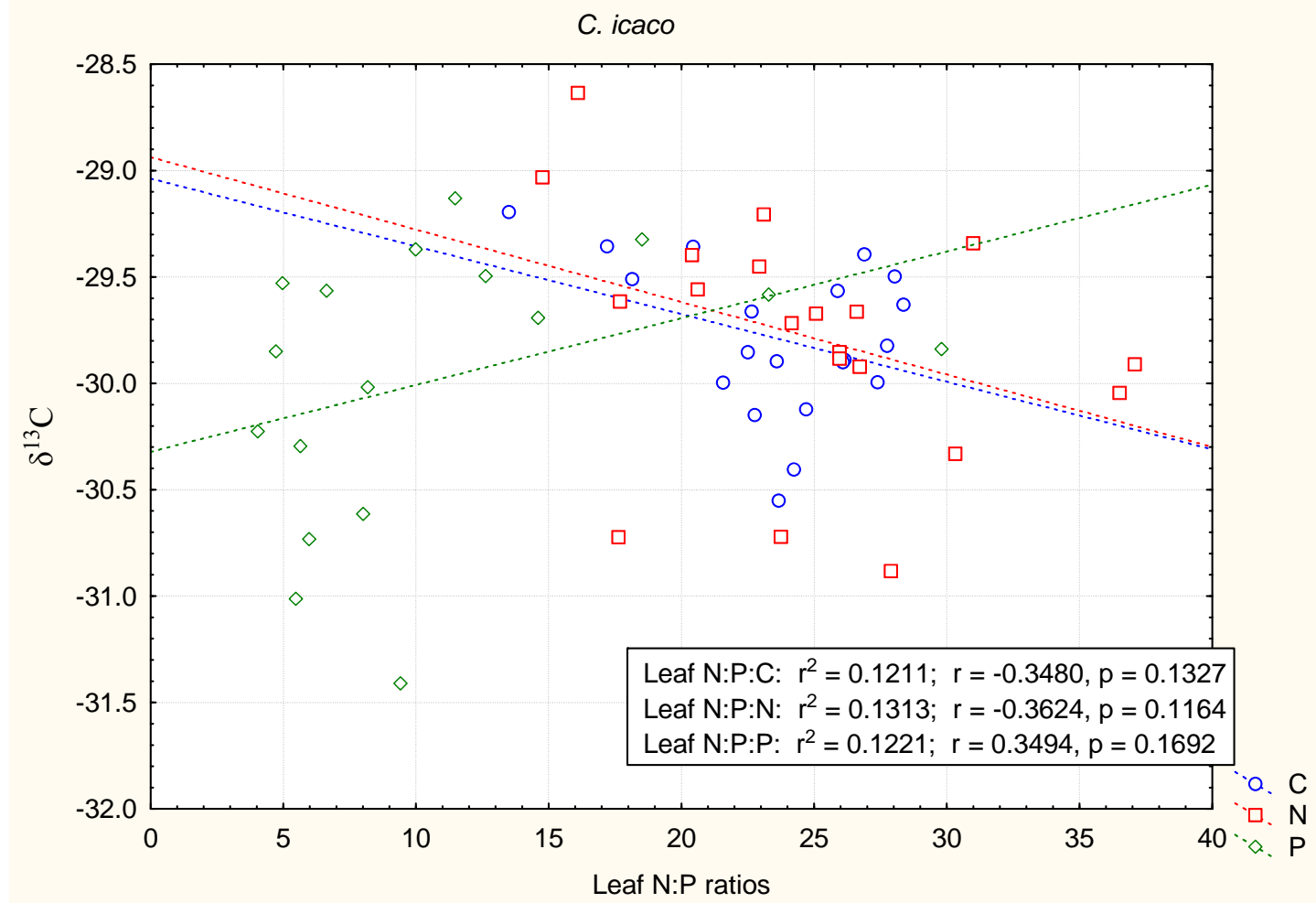

Figure 28. A scatterplot between leaf N:P ratios and leaf $\delta^{13} \mathrm{C}$ of C, N, and P-treatment of C. icaco. Broken lines are showing non-significant patterns. 


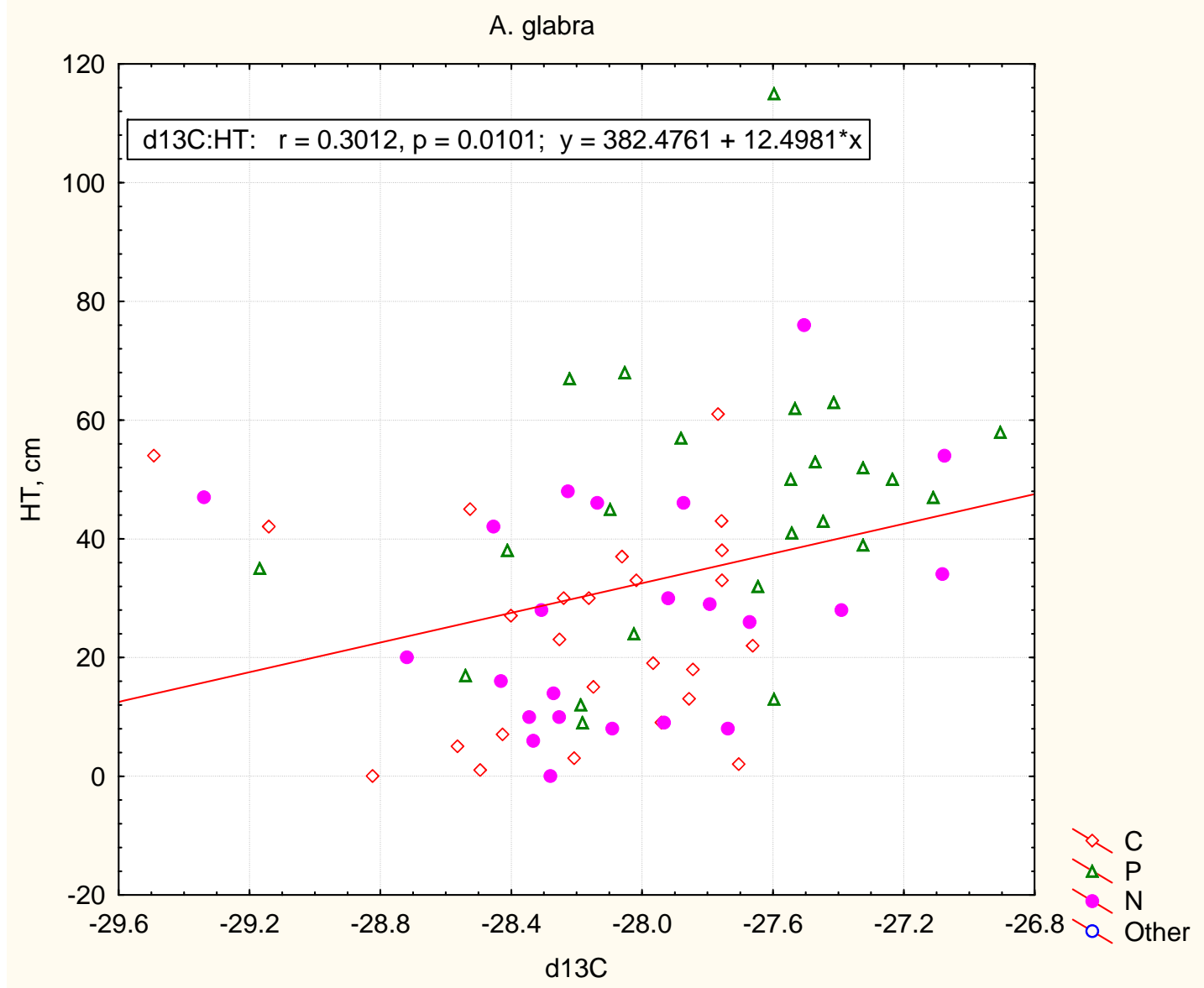

Figure 29. A scatterplot between leaf $\delta^{13} \mathrm{C}$ and growth response ( $\Delta$ height) for $A$. glabra. 


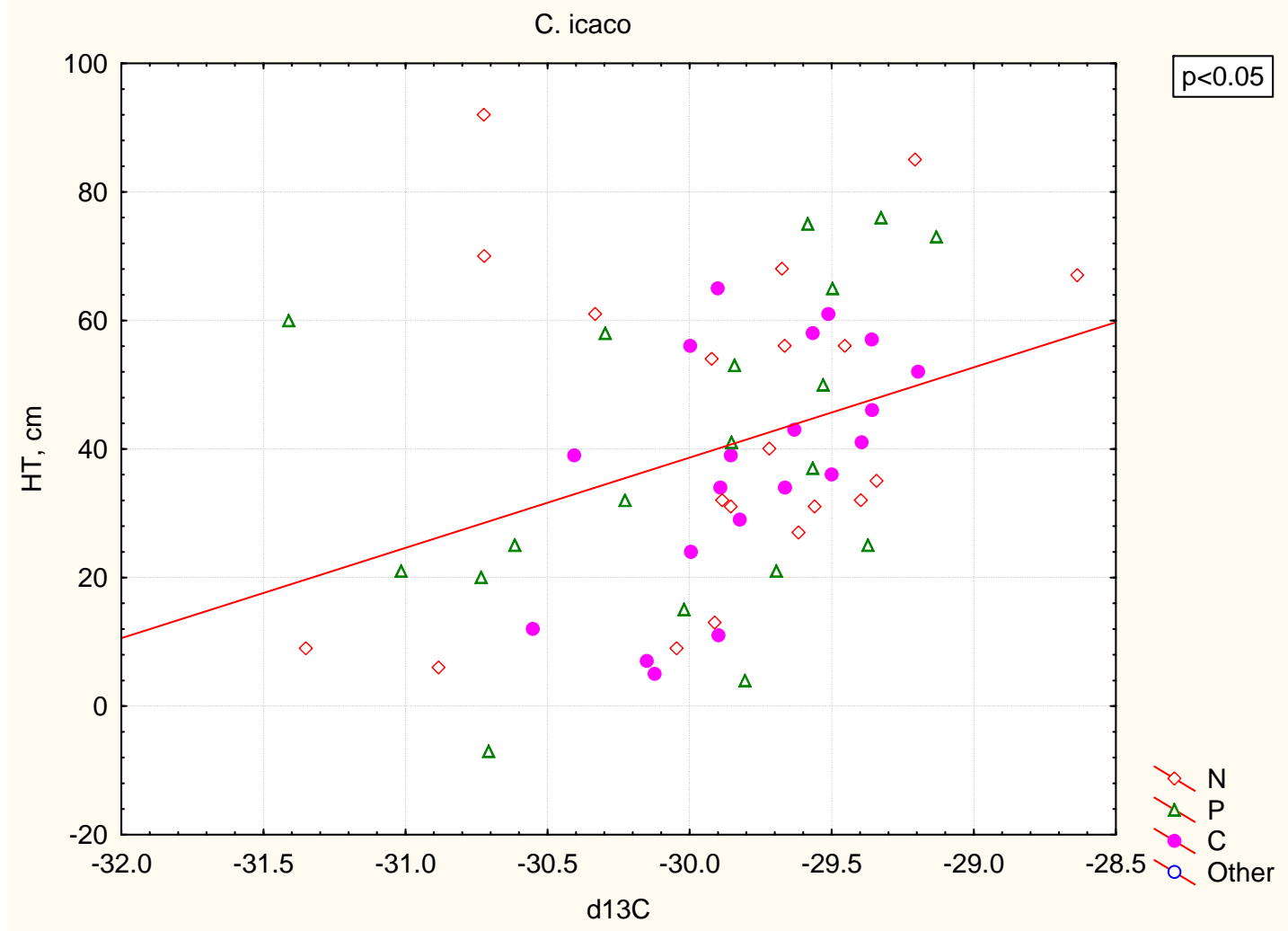

Figure 30. A scatterplot between leaf $\delta^{13} \mathrm{C}$ and growth response ( $\Delta$ height) for C. icaco. 